\title{
The Passive Family in Baltic
}

\author{
Nicole NaU \\ Vilnius University \& Adam Mickiewicz University in Poznań \\ Biruté SPRAunienè \\ Vilnius University
}

VAIVA ŽEimantiené

Vilnius University

Predicative constructions with passive participles in Latvian and Lithuanian exhibit great variation in form, meaning and function, ranging from pure passive to various temporal, aspectual and modal meanings. This paper uses a set of formal and functional parameters to distinguish and profile several types and subtypes of such constructions. These types are mutually related by family resemblance and constitute a 'Passive Family'. They include dynamic and stative passives, three types of resultatives, several types of subjectless (impersonal) passives, modal constructions expressing possibility or necessity, and evidential constructions. Based on a thorough study of corpus data, the paper not only adds new insights about constructions that were already known, but also presents construction types that have not been discussed in the literature on the Baltic passive before: the Lithuanian cumulative-retrospective construction and the Latvian cumulative-experiential subtype.

Keywords: passive, impersonal constructions, cumulative constructions, experiential perfect, evidential, Latvian, Lithuanian, Baltic

\section{Introduction ${ }^{1}$}

What is called 'passive' across languages is often vastly different in structure and even in function.

(Shibatani 2006, 264)

This paper surveys predicative constructions in contemporary Latvian and Lithuanian that contain a passive participle. Most of these constructions have traditionally been regarded as representing the category of passive. Our main idea is that these constructions form a kind of family:

\footnotetext{
1 We would like to thank Axel Holvoet, Peter Arkadiev, Wayles Browne and two anonymous reviewers for their valuable comments on this paper. This research has received funding from the European Social Fund (project No. 09.3·3-LMT-K-712-01-0071) under grant agreement with the Research Council of Lithuania (LMTLT).
} 
within the broad set of constructions with a passive participle as predicate, several types can be distinguished by formal and functional parameters, and these types are mutually related by family resemblance. The goal of this paper is to establish these parameters and the features that characterize construction types and subtypes. Taking up the given quote by Shibatani, we may state that even within one language and within one broadly defined formal type, the constructions called 'passive' are vastly heterogeneous. However, we also see what they have in common-not as necessary defining criteria, but by family resemblance. The paper will not account for all predicative uses of passive participles, but profile the most prominent types found in Latvian and Lithuanian, and discuss transitional areas between such types.

As our point of departure is a formal one, it is necessarily languagespecific. Latvian and Lithuanian are relatively closely related genetically, and the identification of common forms and grammatical categories is usually unproblematic. In addition, separate developments of the common heritage appear more clearly than when comparing more distantly related languages.

In particular, we consider constructions which

i. contain a passive participle,

ii. are used as the predicate of an independent clause

iii. or as the predicate of a type of dependent clause which also uses simple finite verb forms.

Criterion (i) restricts the set of constructions morphologically. Passivelike functions of the reflexive marker are not taken into consideration. They belong to another family, that of the middle voice (Holvoet 2020). Verbs with such a marker are referred to as reflexive verbs in this paper and treated as a lexical class. In Lithuanian, they may also form passive participles, and for individual constructions membership to this lexical class may play a role, which will be pointed out when discussing the respective construction. Criterion (ii) rules out attributive, adverbial or discourse-marker uses of the participle, and criterion (iii) rules out converb clauses, but includes passive constructions in adverbial, complement and 'finite' relative clauses.

To establish types of constructions, we use a mix of bottom-up and top-down approaches. On the one hand, we start by gathering corpus 
examples that meet the above criteria, and analyse the features that distinguish them and may be used to establish groups. Parameters that distinguish types include the choice of auxiliary and participle, the number and coding of arguments, word order, semantic properties of the verb and of the actor, and others. On the other hand, we do not pretend to be ignorant of, but rather try to profit from well-established categories and distinctions such as stative vs. actional (dynamic) passive or personal vs. impersonal passive. However, these established categories are not taken for granted, but evidence for their usefulness and possible modification is searched for in the data.

In our study we used several corpora of contemporary Standard Latvian and Lithuanian (see Sources in the list of references). For particular purposes, we draw samples from one or more of these corpora; the details are explained in the respective section. However, two large samples of passive constructions in Lithuanian were used throughout the study for various purposes, and are therefore best explained here. They were drawn from LithuanianWaC v2, a corpus of internet texts available at https:// www.sketchengine.eu. The corpus contains more than 48 million words and is morphologically annotated. Using the query [tag="Vppnp......"] [tag="Vppnppno"] | [tag="Vppnpsno"] a concordance of 1,340,272 $t$ - and $m$-participles was compiled. Of these, 1500 random examples were downloaded and 'cleaned' from attributive uses and other irrelevant cases. In this way a first sample of 605 examples was obtained (hereinafter Sample 1). A control random sample of 684 examples was obtained by randomized shuffling of the initial concordance twice and again 'cleaning' the first 1500 lines of examples from irrelevant cases (hereinafter Sample 2). In our study, we use these two samples mostly for establishing the frequency of particular phenomena, and compare our findings to those of Emma Geniušienè (2006; 2016), whose work includes the most profound empirical investigation of the passive in Lithuanian.

In Section 2 we present the parameters that we use in characterizing (or 'profiling') types of constructions on the background of the general discussion of passives in the typological literature. Section 3 shows the Latvian construction with the auxiliary tikt 'become, get' and a past passive participle ( $t$-participle) as a typical representative of a basic passive. Section 4 is devoted to the main constructions based on the present passive participle ( $m$-participle) in Lithuanian and Latvian, while Section 5 
discusses types of stative passives. In Section 6 we present the results of our study on what is often called 'impersonal passive' and what we capture under the heading 'subjectless and subject-weak passives'. In Section 7 we come to evidential constructions, with the Lithuanian Evidential probably the most 'estranged' member of the family (or already excluded from it). Each section contains profiles of the established types in form of summarizing tables. The concluding Section 8 summarizes our results in a more general way.

\section{Passives in Baltic: basic types and parameters}

\subsection{Morphology}

The passive in Baltic is a construction consisting of a passive participle and (potentially) an auxiliary. Variation concerns (i) the choice of participle, (ii) the choice of auxiliary, and (iii) agreement features.

The two passive participles in Baltic are the past passive or $t$-participle and the present passive or $m$-participle. In Latvian, only the $t$-participle is used in the passive (but see Section 4.3 for modal constructions with the $m$-participle). The main auxiliaries are būt 'be' and tikt 'get (to); become'. The participle agrees with the subject in number and gender, while the auxiliary agrees in person $(1,3)$. If there is no subject triggering agreement, the default values third person, singular, masculine are used; in this paper, we will gloss an ending with default values as NA for 'non-agreeing' $(2,4)$ and reserve the gloss M.SG for instances of agreement. Nominative case is not glossed in the predicate of a passive construction.

(1) Latvian (LVK2018)

$\begin{array}{lll}\text { Vain- } a & \text { ir } & \text { pierādì-t-a. } \\ \text { guilt(F)-NOM.SG } & \text { be.PRS.3 } & \text { prove-PST.PP-SG.F }\end{array}$

'Guilt has been proven.'

(2) Ir pierādì-t-s, $\quad k a[\ldots]$ be.PRS.3 prove-PST.PP-NA that 'It has been proven that [...]'

(3) Tikām AUX.PST.1PL

$$
\text { uzskati- } t-i
$$
consider-PST.PP-PL.M ǵimen-i. family-ACC.SG 'We were considered a wealthy family.' 
(4) Tiek uzskatī-t-s, $\quad k a[\ldots]$ AUX.PRS.3 consider-PST.PP-NA that

'It is believed that [...]'

The construction with the auxiliary tikt has become the main passive construction in Latvian (see Section 3).

In Lithuanian, both the present and the past passive participle are used in passive constructions, but there is only one auxiliary, büti 'be'. As in Latvian, a nominative subject triggers agreement, cf. $(5,6)$. In constructions without a nominative subject, a special ending is used with the participle (neuter, or non-agreement marking). Details on the use of this ending and examples are presented in Section 2.3.

(5) Lithuanian (ltTenTen14)

$\begin{array}{llll}\text { Heroin-as } & \text { yra } & \text { parduoda-m-as } & \text { maž-ais } \\ \text { heroin(M)-NOM.SG } & \text { be.PRS.3 } & \text { sell-PRS.PP-SG.M } & \text { small-INS.PL } \\ \text { popieri-aus } & \text { pakeli-ais. } & \\ \text { paper-GEN.SG } & \text { package-INS.PL } & \\ \text { 'Heroin is (being) sold in small paper packages.' } & \end{array}$

(6) Beveik vis-i čempionat-o biliet-ai

almost all-NOM.PL.M championship-GEN.SG ticket-NOM.PL.M yra parduo-t-i.

be.PRS.3 sell-PST.PP-PL.M

'Almost all championship tickets have already been sold.'

Verbs with a reflexive marker also have passive participles in Lithuanian. In verbs containing one or more prefixes, the reflexive marker precedes the verbal root, and passive is formed in the same way as with non-reflexive verbs, for example pa-si-im-ti (PVB-RFL-pick_up-INF) 'pick up', $m$-passive: pa-si-im-a-m-as (PVB-RFL-pick_up-PRS-PP-SG.M), $t$-passive: $p a$-si-im-t-as (PVB-RFL-pick_up-PST.PP-SG.M). In verbs without prefixes, the reflexive marker is at the end of a verb form and interacts with the ending. Here, only the non-agreement ending is possible for passive participles, for example moky-ti-s 'learn' (learn-INF-RFL), $m$-participle: mok-o-m-a-si (learn-PRS-PP-NA-RFL), $t$-participle: moky-t-a-si (learn-PST.PP-NA-RFL). In Latvian, a reflexive marker is always at the end of a verbal form, and reflexive verbs do not form passive participles. 


\subsection{Syntax: basic distinctions}

In the linguistic literature, the passive voice or diathesis is defined by the realization of core arguments of a predicate with regard to grammatical relations (subject, direct object, oblique object) and to semantic roles (agent, patient), semantic macroroles (actor, undergoer), or generalized roles (A, $\mathrm{P}) .{ }^{2}$ This realization is usually compared to that found in the (more basic, or unmarked) active voice. For definitions of the passive differing along these lines, but covering the same linguistic phenomena, see, for example, Van Valin (2001, 30); Siewierska (2013); Zúñiga \& Kittilä (2019, 83). In our description, we will use the concept of semantic macroroles as explained in Van Valin (2001) and a traditional concept of subject, characterized by nominative marking and agreement. We will of course not change the terminology of works quoted.

In her work on the passive in Lithuanian, Emma Geniušiene (Geniušienè 2006; 2016) ${ }^{3}$ uses two parameters to distinguish four syntactic types of passive constructions: the presence or absence of a subject (subjectful vs. subjectless constructions) and the presence or absence of an oblique object expressing the agent (agented vs. agentless constructions). The same or similar parameters have figured prominently in discussions about the essence of the passive, the 'prototype' of a passive, and different types of passive constructions in language typology and theoretical linguistics. The simple classification presented in Table 1 is therefore a good point of departure not only for distinguishing constructions found in the Baltic languages, but also for a discussion of their status and characteristics in relation to cross-linguistic tendencies and their interpretation in the linguistic literature.

\footnotetext{
${ }^{2}$ The term LOGICAL SUBJECT used in traditional grammar may be understood as a semantic macrorole (actor).

${ }^{3}$ We cite the English editions of Geniušienè's work. The content of Geniušienè (2016) appeared in Russian in the 1970 .
} 
Table 1. Types of passives according to the presence of undergoer and actor

\begin{tabular}{|c|c|c|c|}
\hline Type & $\begin{array}{l}\text { Undergoer } \\
\text { (subject) }\end{array}$ & $\begin{array}{c}\text { Actor } \\
\text { (oblique) }\end{array}$ & $\begin{array}{l}\text { Corresponding category } \\
\text { or concept }\end{array}$ \\
\hline $\mathrm{i}$ & + & + & $\begin{array}{l}\text { subjectful agented passive } \\
\text { (Geniušiené) } \\
\text { CANONICAL PASSIVE (Siewierska } \\
\text { \& Bakker 2012) }\end{array}$ \\
\hline ii & + & - & $\begin{array}{l}\text { subjectful agentless passive } \\
\text { (Geniušienè) } \\
\text { BASIC PASSIVE (Keenan \& Dryer } \\
\text { 2007) }\end{array}$ \\
\hline iii & - & - & $\begin{array}{l}\text { subjectless agentless passive } \\
\text { (Geniušienè) } \\
\text { SUBJECTLESS PASSIVE; impersonal } \\
\text { passive (various authors) }\end{array}$ \\
\hline iv & - & + & $\begin{array}{l}\text { subjectless agented passive } \\
\text { (Geniušienè) } \\
\text { (no special name, treated together } \\
\text { with iii) }\end{array}$ \\
\hline
\end{tabular}

While Latvian only has agentless passive constructions (Types ii and iii), Lithuanian has constructions of all four types; examples (7)-(10) illustrate Types i-iv, respectively.

(7) Lithuanian (ltTenTen14)

[Ne kiekvienas lietuvis [...] žino, kad]

šios dainos žodžiai parašy-t-i

DEM.GEN.SG.F song(F).GEN.SG word.NOM.PL PVB.write-PST.PP-PL.M poeto Algimanto Baltakio.

poet.gEN.SG PN.GEN PN.GEN

'[Not every Lithuanian [...] knows that] the words of this song were written by the poet Algimantas Baltakis.'

(8) ̌̌ie žodžiai parašy-t-i maždaug DEM.NOM.PL.M $\quad$ word(M).NOM.PL $\quad$ PVB.write-PST.PP-PL.M around XIX amžiaus viduryje.

19th century.Gen.SG middle.LOC.SG

'These words were written around the middle of the 19th century' 
(9) Ne karta not_once rašy-t-a ir kalbe-t $-\boldsymbol{a}$ apie vyru write-PST.PP-NA and talk-PST.PP-NA about man.GEN.PL amžiaus vidurio krizę. 'Men's midlife crisis has been written and talked about more than once.' (literally: “it has been written and talked about men's midlife crisis")

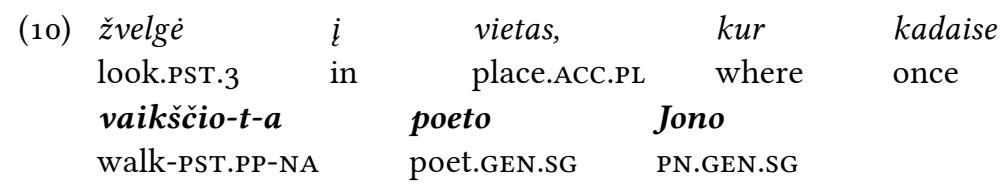

\section{Aleksandravičiaus-Aisčio.}

PN.GEN.SG

'he looked at the places where the poet Jonas Aleksandravičius-Aistis once walked' (literally: 'where it was walked by the poet')

Siewierska \& Bakker (2012) use the term AGENTIVE PASSIVE for passive constructions which contain a subject and allow the addition of an agent phrase. They argue that this type is to be considered as the CANONICAL PASSIVE under the canonical approach to typology, because it fulfills two crucial criteria: (i) the agent phrase distinguishes the passive from other voice constructions such as inverse or anticausative (Siewierska \& Bakker 2012, 153), and (ii), as they show in their paper, the (potential) presence of such a phrase correlates with at least some other features crucial for the passive. Though frequency is not a criterion of canonicity in this approach, the authors point out that among 264 languages of their sample, $65 \%$ had agentive passives and $35 \%$ only agentless ones (ibid., 159). The percentage differs widely across large geographic areas, with Europe showing the highest proportion of languages with an agentive passive. On this background we may state that Lithuanian has a canonical passive, which is typical for a European language, while Latvian belongs to the minority of European languages which do not have this type. Latvian however has an agentive construction which superficially resembles an agented passive, with a genitive that originates in, and is still largely bound to, a noun phrase (see Section 5; Holvoet 2001a and Holvoet et al. 2019 for details). The Lithuanian agent phrase has developed from the same source and 'absorbed' the agentive construction (Holvoet et al. 2019, 226). In addition, mostly in older Latvian an agent phrase with the preposition no 'from' is found, which was identified as a calque from German and consequently 
banned from the standard variety. It may however still occasionally be found, and it is possible that language planning has blocked a process in which it would have become a genuine Latvian means of expressing an agent with the passive. We know from other European languages that agented passives are more frequent in written than in spoken language, and written language is much more influenced by language planning (which in Latvia during most of the 2oth century included strict editing of anything that was published).

Siewierska \& Bakker's concept of the canonical passive is based on the possibility to express the actor as an oblique phrase, not on the actual presence of such an agent phrase in texts (this is a difference to Geniušienè's work). For the latter they use the term EXPLICIT AGENTIVE, as opposed to IMPLICIT AGENTIVE constructions. The proportion of EXPLICIT AGENTIVE passives varies widely across languages that have canonical passives, as well as across constructions and registers within one language. For example, based on corpus studies of the passive in three Mainland Scandinavian languages, Laanemets (2012) shows for each language differences between spoken and written discourse as well as between the synthetic $s$-passive and the periphrastic passive with the auxiliary 'become'. The lowest proportion of agent phrases was found with the $s$-passive in spoken Danish (0.6\%), the highest proportion with the periphrastic passive in written Swedish (19.4\%) (Laanemets 2012, 126). For Lithuanian, we do not have such detailed data, but we suppose that the overall frequency of agent phrases in passive constructions may be lower than in the Scandinavian languages and English. Geniušiene, who worked with a sample of passive constructions from written (mostly fictional) Lithuanian texts, gives figures for different functional types of passive. With the actional passive, $16.7 \%$ of subjectful passive constructions with transitive verbs had an agent phrase (259 of 1552, figures derived from Table 2 in Geniušienè 2006, 40). In her complete sample of 5730 passive constructions, only $6.5 \%$ had an agent phrase (Geniušienè 2016, 146) - the difference being mostly due to the large number of statal passives in the sample, which do not allow an agent phrase (see Section 5). In any case, it is clear that when considering tokens of constructions in actual discourse, the majority in both Latvian and Lithuanian belongs to Type ii.

Keenan \& Dryer (2007, 328-329) define the basic passive by the following features: (i) the construction does not contain an agent phrase, (ii) 
the main verb expresses an action, (iii) it is monotransitive, and (iv) the verbal arguments which are affected by the passive diathesis have the semantic roles of agent and patient. According to the authors, the basic passive so defined is found in all languages that have a passive and may be the only passive construction in a language. Thus, the existence of the basic passive in a language is the prerequisite for the occurrence of other, non-basic types. Non-basic passives which may additionally occur in a language include those with an agent phrase, passives on intransitive or ditransitive verbs, and passives with subjects other than patients (Keenan \& Dryer 2007, 342-352).

The concept of basic passive is more specific than our Type i. Keenan \& Dryer's criteria (ii), (iii) and (iv) cited above draw attention to several factors that distinguish variants of passives with a subject (Type ii as well as Type i).

The question of possible semantic roles of arguments affected by the passive diathesis is related to case marking. In Latvian, only arguments that receive accusative marking in the active voice can be promoted to a nominative subject in the passive, while dative, locative or prepositional arguments retain their marking. The semantic role of an accusative-marked argument seems to be of little importance for its promotion to subject: while it most often is patient or theme, also experiencers occur, for example, with verbs such as (ie)interesēt 'interest', iepriecināt 'make happy', (sa)dusmot 'make angry'. In Lithuanian, arguments of verbs governing the genitive (such as laukti 'wait for', ieškoti 'look for', geisti 'desire', bijoti 'fear') may also become nominative subjects in the passive. These verbs are considered transitive in grammars of Lithuanian (Ambrazas et al. 2006, 223; 278). In addition, dative objects of some verbs (semantically recipients) may be promoted to subject, or alternatively retain dative marking, and the same holds for the locative argument of the verb gyventi 'live, reside' (Ambrazas et al. 2006, 278-279). For more details on oblique passivization in Lithuanian see Anderson (2015).

We will discuss more aspects of the subject of passive constructions in Section 2.3.

Passives without a subject (our Types iii and iv) are most often treated under the name IMPERSONAL PASSIVE; the opposite PERSONAL PASSIVE is less often found as a label for Geniušienë's 'subjectful' constructions (Type $\mathrm{i}$ and ii). As 'impersonal' is used in names of a large variety of construc- 
tions (cf. Malchukov \& Siewierska 2011), some authors avoid the term and prefer SUBJECTLESS PASSIVE (for example, Blevins 2003, who argues for a strict distinction between a subjectless passive and an impersonal-not passive-construction). Type iii is well attested in both Latvian and Lithuanian, although it is clearly less frequent than Type ii. In Geniušienè's sample of 2,464 actional passive clauses, $33 \%$ were subjectless agentless and $52.2 \%$ subjectful agentless passives (Geniušienè 2006, 40, table 2). Most intransitive verbs can form a passive of Type iii, including verbs with a non-agentive, non-volitional subject such as 'fall', 'be ill'. There are however two general restrictions, one semantic and one formal: only verbs which may have a human subject in the active, and only verbs which have a nominative subject in the active can be passivized.

While subjectless passives are found in many languages, it is less common for them to include an agent phrase (our Type iv), as in the Lithuanian example (10). Indeed, this construction seems to be at odds with the functions usually ascribed to the passive: if the actor is known and present in the sentence, and nothing else is promoted to subject, why use a passive construction? Geniušiene $(2016,46-47)$ argues that this type is motivated stylistically, being more expressive than a corresponding active. On the one hand, as with agentless subjectless passives, the emphasis is laid on the action expressed by the verb, while the actor is demoted. On the other hand, this actor expressed by a genitive phrase functions as a pragmatic link with the previous context.

The frequency of Type iv relative to Type iii is slightly lower than that of Type i relative to Type ii. According to the data given in Geniušienè's table for actional passives, about $10 \%$ (91 of 911) of subjectless passives in her sample had an agent phrase, compared to $16.7 \%$ of passives with a subject, as mentioned above (derived from Geniušienè 2006, 40). ${ }^{4}$ This figure corresponds to our observations. For example, among 83 occurrences of a passive construction of the Lithuanian verb vaikščioti 'walk' with the past passive participle in the corpus ltTenTen14, 11 had an agent phrase (13.3\%). Additionally, 18 constructions with an agent phrase were identified as evidential (see Section 7.1 for the Lithuanian Evidential). In our opinion it is important to distinguish between passive and evidential, as

\footnotetext{
${ }^{4}$ Later in the same chapter, Geniušiene gives the much lower figure of 16 clauses of the subjectless agented type (Geniušienè 2006, 46)—maybe a mistake?
} 
Geniušienè does in the cited article. In her earlier work she had treated these constructions together and derived the conclusion that "the oblique agent is especially common with intransitive verbs" (Geniušienè 2016, 146).

While for language typology and theoretical linguistics, the difference between canonical and non-canonical, basic and non-basic, or impersonal and personal passives is doubtlessly of importance, the types distinguished in Table 1 do not constitute bundles of formal and functional features that would make them separate members of the Passive Family in Baltic. On the one hand, these types are more broadly defined, and on the other hand, some features cut across the types (see Section 2.5 for our list of features).

\subsection{Subjects in passive constructions}

So far, we have used the term subject to refer to arguments with nominative marking that trigger agreement with the predicate. In this section we will discuss which other arguments could be regarded as subjects in a passive construction. Put otherwise: should all constructions without a nominative subject be regarded as subjectless passives?

In Lithuanian, there is a small group of pronouns which do have nominative case, but no gender or number, and therefore do not trigger agreement (kas 'what, who', niekas 'nothing, nobody', viskas 'everything, everybody', keletas 'some, a few, several'). The participle in constructions with such a pronoun takes the non-agreement (neuter) ending.

(11) Lithuanian (DLKT)

$\begin{array}{llll}\text { Kas } & \check{z} a d \dot{e}-t-a, & \text { turi } & b \bar{u} t i \\ \text { what.NOM promise-PST.PP-NA } & \text { must.PRS.3 } & \text { be.INF } \\ \text { padary- } t \text { - } a . & & \\ \text { PVB.do-PST.PP-NA } & & \\ \text { 'What was promised has to be done.' } & \end{array}$

(12) Lithuanian (DLKT)

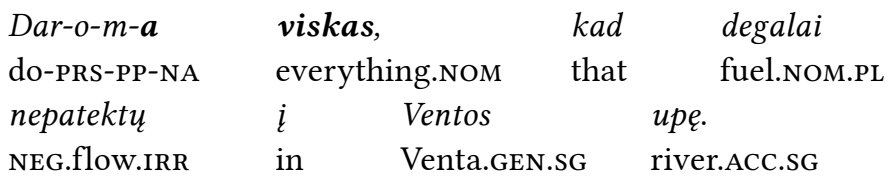

'Everything is being done in order to prevent the fuel from flowing into the river Venta.' 
(13) Lithuanian (DLKT)

$\begin{array}{lcl}\text { Pakvies-t-a } & \text { keletas } & \text { vaiku. } \\ \text { invite-PST.PP-NA } & \text { some.NOM } & \text { child.GEN.PL } \\ \text { 'Several children have been invited.' } & \end{array}$

Ambrazas et al. (2006, 238) consider the pronouns in (11) and (12) and the phrase in (13) subjects of personal passive constructions. They possess one subject property-the nominative case.

Corresponding pronouns in Latvian (kas 'what, who', nekas 'nothing') can be interpreted as having masculine gender and thus triggering agreement. However, as a masculine singular ending is also used in situations of non-agreement, there is no formal difference.

There are also other occasions where in Lithuanian the neuter form of the passive participle co-occurs with an NP in the nominative: when the subject is a collection of items (14), or when two alternatives are confronted (15):

(14) Lithuanian (DLKT)

$\begin{array}{llll}\text { Kas-a-m-a } & \text { anglys, } & \text { geležies } & \text { rūda } \\ \text { mine-PRS-PP-NA coal.NOM.PL } & \text { iron.GEN.SG } & \text { ore.NOM.SG } \\ \text { ir } \quad \text { gipsas. } & & \\ \text { and gypsum.NOM.sG } & & \\ \text { 'Coal, iron-ore and } & & \end{array}$

(15) Lithuanian (DLKT)

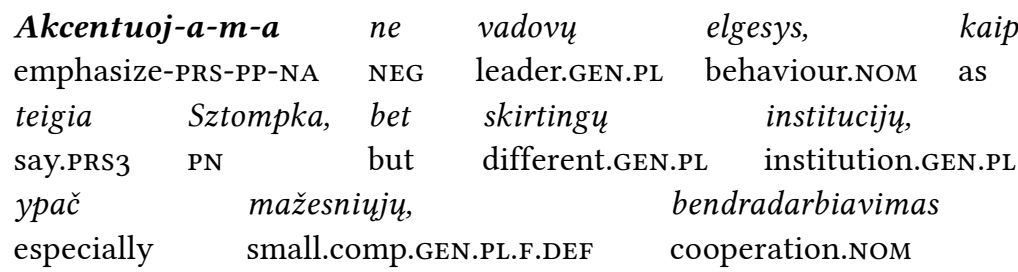

'Emphasis is not laid upon the leaders' behaviour, as suggested by Sztompka, but on cooperation between different institutions, especially the smaller ones'

We would argue that the nominative NPs in examples (14-15) are subjects of personal passive constructions. The object has been promoted to subject since it occurs in the nominative case. Thus, agreement is not a necessary criterion for subjects in Lithuanian passive constructions. 
It is generally assumed (cf. Ambrazas et al. 2006, 280) that partitive objects of transitive verbs are not promoted to subject in the passive, and passives with partitive genitives as in (16b) are regarded as subjectless, in contrast to those with a definite nominative subject (16c). The difference in word order seen in (16b) and (16c) is a strong trend, but in certain contexts, definite nominative subjects may also follow the verb (16d).

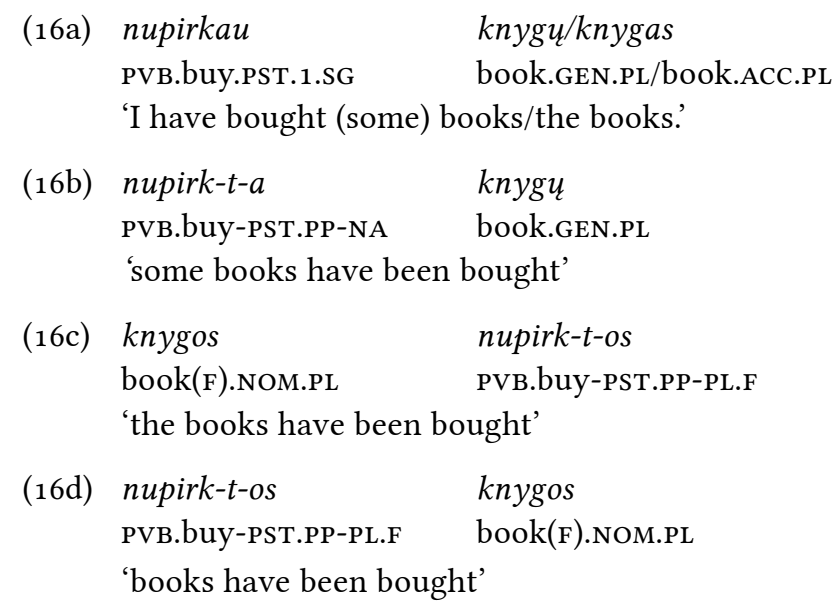

What is the syntactic function of the partitive genitive in (16a) and (16b)? Holvoet and Semėnienè $(2004,25)$ argue that in partitive objects the genitive case is a semantic case which is 'laid upon' the structural case, namely the accusative. That is, in partitive objects of transitive verbs the accusative marking of the object is present but not visible because of the semantic case which overshadows it and conveys additional meaningthat of indefinite quantity. Consequently, both partitive and accusative objects in (16a) are considered transitive objects. What happens when a transitive clause with a partitive object is passivized? Shall we assume that a partitive object (as all transitive objects) is promoted to subject and acquires nominative case marking which is again overshadowed by the genitive case? Or shall we say that partitive objects, due to the lack of canonical marking, are not promoted to subject in the passive? Both interpretations seem plausible. Other criteria for subjecthood, such as the possibility to bind reflexive pronouns, are not always applicable (cf. Sprauniene et al. 2015). Authentic examples are rare, and constructed examples get divergent acceptability judgements by native speakers. Thus, the syntactic function of partitive NPs in passive clauses is not clear and 
sentences like (16b) are syntactically ambiguous between subjectful and subjectless passives (cf. Geniušienè 2016, 144).

Latvian is different: it clearly prefers canonical subjects in both voices. It also prefers agreement. Quantifiers such as $d a u d z$ 'a lot of', maz 'few', pāris 'a couple', cik 'how many, how much' may govern a genitive, but they may also be combined with a nominative. The nominative is generally used when the noun is additionally modified by adjectives, and we get a canonical subject. Compare the Latvian and the Lithuanian versions of a sentence from the parallel corpus LiLa in (17), (18).

(17) Latvian ( LiLa)

Cik gan skaist-i un neparast-i

how.much PTC nice-NOM.PL.M and unusual-NOM.PL.M stāst-i ir uzrakstī-t-i,

story-NOM.PL be.PRS.3 PVB.write-PST.PP-NOM.PL.M

[mizojot kartupeļus, lasot mellenes, ravējot, ejot vienkārši no punkta A uz punktu B.]

'How many nice and unusual stories have been written [while peeling potatoes, picking blueberries, weeding, or simply going from point A to point B.]'

(18) Lithuanian (LiLa)

Kiek $\quad \check{z} a v i-\boldsymbol{u}_{\mathbf{z}} \quad$ ir $\quad$ ypating-u

how.much nice-GEN.PL and unusual-GEN.PL

apsakym-u parašy-t-a

story-GEN.PL PVB.write-PST.PP-NA

[skutant bulves, renkant mélynes, ravint, paprasčiausiai einant iš taško A i taška B].

'How many nice and unusual stories have been written [while peeling potatoes, picking blueberries, weeding, or simply going from point A to point B.]'

When a quantifier is used with a genitive singular in Latvian, the participle usually has the default ending masculine singular. However, with a noun phrase in the genitive plural, the participle in a passive construction most often shows agreement in number and gender. This can be seen in (19): the noun südziba 'complaint' is feminine and appears in the clause in genitive plural. The passive participle is marked for feminine and plural in agreement with this noun, but has nominative marking as required by the construction. 
(19) Latvian

\begin{tabular}{|c|c|c|c|c|}
\hline Loti & $d a u d z$ & $s \bar{u} d z$ & & \\
\hline very & much & comp & t(F)-GEN.PL & X.PST.3 \\
\hline iesnieg & & $L R$ & Izglìtības & ministrijā, \\
\hline dge- & PP-NOM.PL.F & LR & education.GEN.SG & ministry.LOC.sG \\
\hline out & $\begin{array}{l}\text { to, } \\
\text { DEM.ACC.SG }\end{array}$ & $\begin{array}{l}k a . \\
\text { tha }\end{array}$ & & \\
\hline
\end{tabular}

'Very many complaints were lodged at the Latvian Ministry of Education about $[\ldots]$ '

Thus, in both languages we find arguments that have only one of two morphological subject features (nominative or agreement), as well as arguments which have neither. To the latter category we may add complement clauses and infinitives. Such verbal arguments may express the theme, for example, of verbs of saying or planning. They have the same syntactic function as nominalizations, which trigger agreement. Compare (20) with an infinitive and (21) with a noun.

(20) Latvian (LVK2018)

$\begin{array}{llll}\text { Pirmajā } & \text { posmā } & \text { ir } & \text { plāno-t-s } \\ \text { first.LOC.SG.DEF } & \text { stage.LOC.SG } & \text { be.PRS.3 } & \text { plan-PST.PP-NA } \\ \text { rekonstrue } \overline{-}-\boldsymbol{t} & \text { esošās } & & \bar{e} k a s \\ \text { reconstruct-INF } & \text { existing.ACC.PL.F.DEF } & \text { building.ACC.PL }\end{array}$

'In the first stage it is planned to reconstruct the existing buildings.'

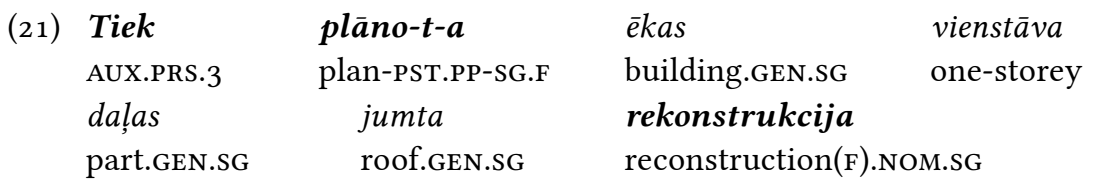

'The reconstruction of the roof of the one-storey part of the building is being planned.'

Instead of, or in addition to, categorizing passive constructions according to the presence vs. absence of a subject, it is useful to distinguish constructions according to transitivity. Verbs such as Latvian plānot 'plan', which allow both verbal complements and nominal, accusative-marked, direct objects, are transitive. All examples given above with a quantified genitive noun phrase likewise contained transitive verbs. In all these instances the 'doubtful' subject (lacking one or both morphological characteristics of subjects) alternates with a canonical subject. A bit different is the case of Lithuanian verbs with a lexical genitive complement which does not 
alternate with an accusative. As mentioned above, these verbs are also considered transitive in grammars of Lithuanian.

We are not aware of a difference, with respect to the passive, between monotransitive and ditransitive verbs in Latvian or Lithuanian. Therefore, we propose to distinguish only between transitive and intransitive verbs. Intransitive verbs may be further classified according to the number and the forms of their arguments. In Baltic, not all intransitive verbs have a nominative subject (in the active). Those that don't, seem to defy passivization, while monovalent verbs with a nominative subject in their argument structure are often found in subjectless passives. We may establish the following correspondences between case frames and the syntactic types of Table 1 above:

(22) (a) Verbs with a nominative subject and an accusative object in their argument structure form passives of Type ii (and i in Lithuanian).

(b) Verbs with a nominative subject in their argument structure form passives of Type iii (and iv in Lithuanian).

Note that (22b) includes transitive as well as intransitive verbs and says nothing about other arguments that may be present in the construction.

Additional parameters for categorizing Baltic passive constructions with a subject are word order and definiteness. We have already seen (for example, in (16b) vs. (16c) above) that indefinite subjects usually follow the verb, while definite subjects precede it. We have found that passives with indefinite nominative subjects are used in construction types which are typical for subjectless passives. An example is the cumulative construction (Section 6.3) and other listings of activities.

\subsection{Actionality and aspect}

One of the defining features of the basic passive according to Keenan \& Dryer (2007) was that the verb expresses an action. They formulate the following cross-linguistic generalization:

G-2.2: If a language has passives of stative verbs (eg. lack, have, etc.) then it has passives of verbs denoting events. (Keenan \& Dryer 2007, 331)

The Baltic languages comply with this generalization. Passives of stative verbs may be less common in Latvian, but this is probably a side 
effect of other restrictions (no passive without a nominative subject in the argument structure, no passive with certain experiencer verbs, no passive of reflexive verbs).

Two further generalizations by Keenan \& Dryer (2007) are interesting for a comparison of Latvian and Lithuanian:

G-3: Languages with basic passives commonly have more than one formally distinct passive construction. (Keenan \& Dryer 2007, 340)

G-5: If a language has two or more basic passives they are likely to differ semantically with respect to the aspect ranges they cover. (Keenan \& Dryer 2007, 340)

In correspondence with Keenan \& Dryer's G-3 we find two different morphological types of passive in both languages: In Latvian, the difference is in the choice of auxiliary ( $b \bar{u} t$ 'be' vs. $t i k t$ 'get, become'), in Lithuanian in the choice of participle ( $t$-participle vs. $m$-participle); see Section 2.1 above. Corresponding to G-5, these constructions indeed differ with respect to aspect, if 'aspect' is understood in a broad sense, but they do so in a different way.

In Latvian, the two constructions are divided with respect to actionality: the passive with tikt is mainly used for an actional, dynamic passive, while the passive with $b \bar{u} t$ is used in stative passive constructions. In line with this, the two constructions are associated with particular aspectual classes of verbs, such that the actional passive is found more often with atelic verbs and the stative passive as a resultative with telic verbs (see Section 5), but this is no absolute rule: both construction types are used with a broad range of verbs.

In Lithuanian, $m$-passives are always dynamic (actional) regardless of the actionality class of the input verb while $t$-passives, which may also be formed of different verbs in terms of aspect and actionality, can be both dynamic and stative (see Section 5 for details). Lithuanian may thus be a better illustration for Keenan \& Dryer's generalizations.

A congruence between the Lithuanian $m$-passive and the Latvian passive with tikt is most often found in the present tense, when describing an activity or process going on at reference time, or a situation occurring habitually, see (23a, b). 
Examples from the parallel corpus LiLa: ${ }^{5}$

(23a) Latvian

$\begin{array}{llll}\text { Ostā } & \boldsymbol{t i e k} & \boldsymbol{k r a ̄ s o - t}-\boldsymbol{i} & k u g ̛ ́ i . \\ \text { harbour.LOC.SG } & \text { AUX.PRS.3 } & \text { paint-PST.PP-PL.M } & \text { ship.NOM.PL }\end{array}$

(23b) Lithuanian

$\begin{array}{lll}\text { Uoste } & \text { daž-o-m-i } & \text { laivai. } \\ \text { harbour.LOC.SG } & \text { paint-PRS-PP-PL.M } & \text { ship.NOM.PL }\end{array}$

'Ships are (being) painted in the harbour.'

In the past tense, on the other hand, aspect and the actionality of the verb play an important role for the choice of passive construction in Lithuanian, but not in Latvian. Lithuanian uses the $m$-passive in the past mostly for atelic processes and activities, while with telic verbs the $t$-participle is preferred. As Holvoet (2001b, 165) observed, this leads to a homonymy of stative and dynamic passive in Lithuanian, where Latvian makes this distinction by the choice of auxiliary. The choice between the two morphological constructions in the past tense in each language is triggered also by other factors, so that it is difficult to establish general rules for when Latvian $t i k t+t$-participle corresponds to a Lithuanian $m^{-}$ participle and when to a $t$-participle. Some tendencies will be shown in Sections below dealing with individual types of construction.

In both languages, the dynamic passive is younger than the stative passive. Its development can be traced in written documents from the 16th century and later (see Ambrazas 1990, 191-192 for the spread of the dynamic passive in Lithuanian, and Veidemane 2002, 419-422 for Latvian; a summary is given in Nau \& Holvoet 2015, 10).

\subsection{Parameters that distinguish members of the Passive Family}

The individual morphological, syntactic, and semantic divisions reviewed in the above sections are not sufficient on their own to establish different types of constructions. Rather, such types arise as clusters of several such features. Features mentioned in the above discussions mostly concerned the form of construction. They are listed in Table 2:

\footnotetext{
${ }^{5}$ Here and further on, examples given in both Latvian and Lithuanian from the parallel corpus LiLa are translated only once into English if they are semantically fully equivalent.
} 
Table 2. Formal parameters that distinguish passive constructions

\begin{tabular}{|c|c|}
\hline Parameter & Value \\
\hline Participle & $t$ - (PST.PP) or $m$ - (PRS.PP) \\
\hline Agreement & $\begin{array}{l}\text { number and gender vs. none/default; agreement in } \\
\text { case other than nominative }\end{array}$ \\
\hline Auxiliary & 'be', 'become/get', other, no auxiliary \\
\hline Agent phrase & present vs. absent; possible vs. impossible \\
\hline Subject & $\begin{array}{l}\text { canonical subject (nominative, agreement), } \\
\text { other subject, no subject }\end{array}$ \\
\hline $\begin{array}{l}\text { Argument } \\
\text { structure }\end{array}$ & $\begin{array}{l}\text { transitive vs. intransitive verb; promoted } \\
\text { vs. non-promoted arguments }\end{array}$ \\
\hline $\begin{array}{l}\text { Semantic role } \\
\text { (subject) }\end{array}$ & patient, theme, other \\
\hline $\begin{array}{l}\text { Definiteness } \\
\text { (subject) }\end{array}$ & $\begin{array}{l}\text { subject definite, specific, non-specific; individuated, } \\
\text { non-individuated }\end{array}$ \\
\hline Word order & $\begin{array}{l}\text { position of the subject: preceding or following the verb; } \\
\text { position of the verb relative to other arguments and } \\
\text { adjuncts }\end{array}$ \\
\hline
\end{tabular}

In Section 2.4 we turned to semantic features of the construction (actional vs. stative passive) as well as the verbs (for example, telic, atelic). Another important facet may be semantic features of the demoted actor-for example, it is cross-linguistically common that impersonal passives imply a human (generic) actor (Frajzyngier 1982). As we expand our investigation to constructions that are not purely passive, another parameter is the main meaning or function of the construction, which may belong to the temporal, modal, or evidential sphere. Finally, the overall frequency of a construction may be of importance, as well as its connection to specific registers, though it is often impossible to give reliable numbers for the occurrence of a certain construction in corpora. 
Table 3. Parameters of meaning, function and usage

\begin{tabular}{|c|c|}
\hline Parameter & Value or question \\
\hline Actionality & actional (dynamic) versus stative passive \\
\hline Aspectuality (verbs) & $\begin{array}{l}\text { Is the construction used only or mostly with verbs } \\
\text { of certain classes, such as telic vs. atelic verbs; pro- } \\
\text { cess vs. state; Vendler's classes; other? }\end{array}$ \\
\hline $\begin{array}{l}\text { Features of the } \\
\text { demoted actor }\end{array}$ & $\begin{array}{l}\text { Is the construction restricted to situations where the } \\
\text { underlying actor has one or more of the following } \\
\text { characteristics: human, definite, specific, indefinite, } \\
\text { plural, maybe other? If there is no restriction, are } \\
\text { there preferences? Does the construction imply } \\
\text { such characteristics of the actor? }\end{array}$ \\
\hline $\begin{array}{l}\text { Meaning of the } \\
\text { construction }\end{array}$ & $\begin{array}{l}\text { 'pure passive' vs. expression of temporal, aspectual, } \\
\text { modal or evidential meanings, such as: resultative, } \\
\text { habitual, experiential, deontic modality, indirect } \\
\text { evidentiality, reportative }\end{array}$ \\
\hline Frequency & frequent, well attested, rare \\
\hline Registers & Is the construction (more) typical for certain registers? \\
\hline
\end{tabular}

In the following sections we will describe several types of constructions that can be distinguished by these parameters.

\section{A typical basic passive: Latvian constructions with $t i k t$ and $t$-participle}

The construction with the auxiliary tikt and a $t$-participle is highly grammaticalized and frequent in contemporary Latvian. This is astonishing, as it seems to be a rather young construction, having gained ground only in the 19th century and spread during the 2oth century. The lexical meanings of tikt include 'get to' and 'become'; for an overview of meanings of this verb and constructions in which it is used see Daugavet \& Holvoet (2019, 113-120). 
In Old Written Latvian we find a passive construction with the auxiliary tapt or, less often, kḷūt, both meaning 'become'. This construction largely reflects the German passive with the auxiliary werden 'become'. As the authors of Old Written Latvian were native speakers of German and the construction is (almost) not found in folk songs, it is probable that it arose as a calque. This passive construction was most frequent in the Bible translations of 1689 and 1739 (Veidemane 2002, 416). Veidemane gives figures for the occurrence of the construction in 20,000-word samples of the two Bible translations and two texts from the beginning of the 19th century, which sum up to 563 occurrences in 80,000 words, thus 7037.5 per million. In the second half of the 19th century, the auxiliary tikt starts to appear as a competitor to tapt. At the same time, the frequency of the construction (with all three auxiliaries together) drops drastically: in four samples of texts written by native speakers of Latvian in the second half of the 19th century, Veidemane found 172 tokens in 80,00o words, thus 2150 per million (Veidemane 2002, 416). In the course of the 20 th century, tikt becomes the only regular auxiliary for dynamic passives, while tapt is now archaic and found only in fiction as a stylistically marked variant. With the change of auxiliary, the passive with 'become' has become a genuine Latvian construction, and its frequency seems to be still on the rise.

Endzelin $(1923,764)$, whose grammar reflects the situation at the beginning of the 2oth century, states that the construction with the auxiliary but 'be' is more common as a passive than the one with an auxiliary 'become'. One hundred years later, the situation is reversed. In the balanced corpus LVK2018, the combination of būt and an immediately following past passive participle has a frequency of 1811.1 per million, and this combination is not always a passive construction. However, the combination of tikt and an immediately following past passive participle has a frequency of 3056.9 per million ( 37567 tokens), and it is likely that almost all instances of this combination represent the passive with tikt. In a random sample of 500 tokens of tikt PST.PP drawn from LVK2018, all observations represented the passive construction.

In another random sample of 250 observations of the word form tika (third person past tense of $t i k t$ ), 235 (94\%) were examples of the passive construction-this is remarkable, given that the verb tikt has several other functions. Furthermore, in 229 of these 235 examples the participle immediately followed the auxiliary ( $t i k a$ PST.PP), in only one instance it 
preceded it (PST.PP tika), and in 5 instances the two words were separated by an adverb (tika ADV PST.PP). This shows a very high cohesiveness of the construction tikt PST.PP and may be another reason why constructions with an agent phrase in the genitive or with the preposition no are so rare: these elements would split the two parts of the periphrastic verb form. In the largest Latvian corpus lvTenTen14, 18 occurrences of an agent phrase with no 'of, from' in the position between the auxiliary tikt and the past passive participle were found (o.03 per million). More than half $(\mathrm{N}=10)$ came from a religious context, which mirrors the language of the earlier Bible translations and is a special register (viss tiek no Dieva dots 'everything is given by God'; Jēzus tika no Sātana kārdināts 'Jesus was tempted by Satan'). Some tokens came from sources where it was not clear whether the authors were native speakers of Latvian. However, a few remaining observations show that a passive of Type $i$ is possible in contemporary Latvian, though extremely rare. Example (24) comes from a speech of a Latvian native speaker (who also was known as the author of poems and song texts) in parliament.

(24) Latvian (lvTenTen14)

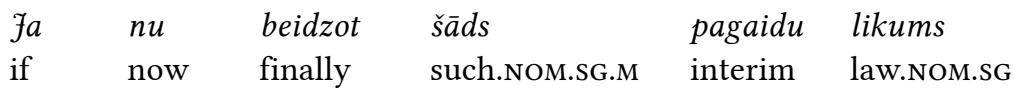

$\begin{array}{llll}\text { tiek } & \text { no } & \text { Saeimas } & \text { atcel-t-s, } \\ \text { AUX.PRS.3 } & \text { from } & \text { Saeima.GEN.SG } & \text { abolish-PST.PP-SG.M }\end{array}$

[tad ceḷas visdažādākie nevēlami sarežğḡijumi i privātās tiesībās, $i$ valsts dzīvē vispārīgi.]

'If now such an interim law is finally repealed by the Saeima, [all kinds of unwanted complications arise both in private rights and in the state's life in general.]'

Similarly rare and mostly found in religious texts are agent phrases in the genitive without preposition (Jēzus tika Jāna kristīts 'Jesus was baptized by John', tika velna kārdināts 'was tempted by the devil'). In the overwhelming majority of uses, there is no agent phrase in a passive construction with the auxiliary tikt. The deleted actor is typically human, though non-human actors are possible with transitive verbs. In the basic passive, the deleted actor is most often indefinite, an individual or group of persons unknown or not specified.

The corpus LVK2018 allows the comparison of usage across registers. The results for the sample of 500 instances of tikt PST.PP are as may be 
expected for a European passive in written language: it is relatively more frequent in academic prose and press texts and (much) less frequent in fiction.

Table 4. Latvian passive with tikt across registers

\begin{tabular}{l|l|l|l}
\hline Register & $\mathrm{N}$ & $\%$ & $\%$ of register in the corpus \\
\hline PRESS & 334 & 66.8 & 57.42 \\
FICTION & 25 & 5.0 & 20.64 \\
ACADEMIC & 87 & 17.4 & 10.05 \\
LAW & 31 & 6.2 & 7.47 \\
PARLIAMENT & 15 & 3.0 & 2.20 \\
OTHER & 8 & 1.6 & 2.15 \\
& 500 & $100 \%$ & $100 \%$
\end{tabular}

The overwhelming majority of examples are in third person. Of the other persons, only first person singular is found 4 times ( 1 in present and 3 in past tense). The construction is used most often with the auxiliary in simple tense forms (present > past $>$ future).

Table 5. Tense and mood forms of tikt in the sample

\begin{tabular}{l|l|l}
\hline Form & absolute & $\%$ \\
\hline PRS & 219 & 43.8 \\
PST & 173 & 34.6 \\
FUT & 68 & 13.6 \\
PST.PA & 11 & 2.2 \\
IRR & 10 & 2.0 \\
EVI & 2 & 0.4 \\
INF & 17 & 3.4 \\
all & 500 & 100
\end{tabular}


The lexical verbs found in this construction belong to various classes. Both telic and atelic verbs are used.

The great majority of constructions in the sample contains a nominative subject ( 473 of $500=94.6 \%)^{6}$ and thus corresponds to the basic passive (Type ii). Most of the constructions without a nominative subject contain a clause or infinitive instead. As argued above, these should also be counted as subjectful passives. The sample contains no example of a passive from an intransitive verb, which shows that these are relatively rare with tikt, though they do exist (see Section 6).

The nominative subject appears before the verb in 266 clauses and follows the verb in 207 clauses, which shows the flexibility of Latvian word order and its importance for information structure. In examples where the subject follows the verb, there is often another argument or an adverbial of place or time preceding the verb, expressed by a noun phrase in the locative or dative or by a prepositional phrase. Example (25) shows a preverbal subject that is the topic; it also shows the contrast between the construction with $b \bar{u} t$ 'be' with perfect or resultative meaning (see Section 5.1) and the passive with tikt in past and present tense with habitual meaning.

(25) Latvian (LVK2018)

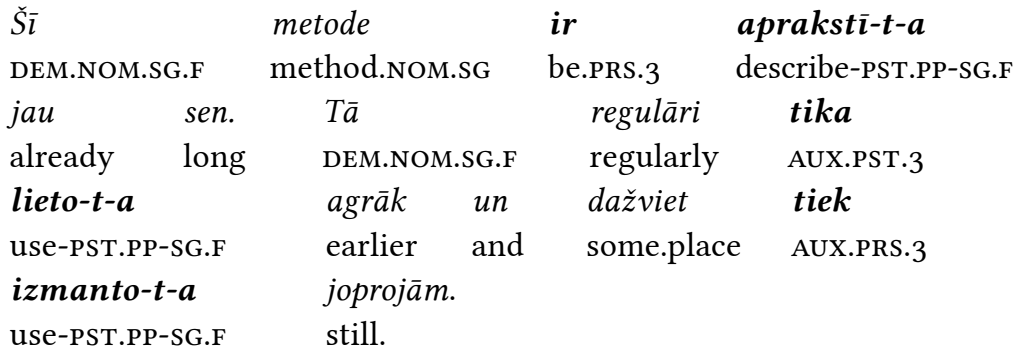

'This method has been described for a long time. It was regularly applied in earlier times and is still used in some places.'

When the subject follows the verb, it is usually not the topic but belongs to the rheme. An idiomatic English translation most often will use the active voice and the word order differs (26), or the topic element has to be made the subject of a passive construction (27).

\footnotetext{
${ }^{6}$ This includes two instances where first person singular is expressed by agreement marking only.
} 
(26) Latvian (LVK2018)

$\begin{array}{llll}\text { Tieši } & t \bar{a} p \bar{e} c & \text { Alfonam } & \text { tiek } \\ \text { exactly } & \text { therefore } & \text { Alfons.DAT.SG } & \text { AUX.PRS.3 } \\ \text { meklē-t-s } & & \text { draugs. } & \end{array}$

search-PST.PP-SG.M friend.NOM.SG

'That is why they are looking for a friend for Alfons.' ('Alfons' is topic)

(27) Latvian (LVK2018)

Viņam tika veik-t-a operācija.

3.SG.DAT.M AUX.PST.3 carry_out-PST.PP-SG.F operation.NOM.SG

'He was operated on.' (literally: 'to him an operation was carried out';

'he' is topic)

With a subject that is not a topic, and is indefinite and not individuated, as in (28), the construction is similar to an impersonal passive. We call such subjects 'weak'. With weak subjects and in subjectless passives, the deleted actor is most typically either generic, as in (28), or a known individual (see Section 6).

(28) Latvian (LVK2018)

[Vasara sākas ar vairums pḷavu augu uzziedēšanu.]

$\begin{array}{lll}\text { Tiek } & \text { plau-t-s } & \text { siens. } \\ \text { AUX.PRS.3 } & \text { mow-PST.PP-SG.M } & \text { hay(M).NOM.sG }\end{array}$

'[Summer begins with the blossoming of the majority of grassland plants.] Hay is made / People make hay.'

The undergoer of a transitive verb may also be deleted, resulting in a passive construction of Type iii, as in (29). The participle takes the nonagreement ending.

(29) Latvian (LVK2018)

[Tā vietā, lai tiktu risināti šie emocionālie jautājumi,]

tiek

$\bar{e} s-t-s$.

AUX.PRS.3

eat-PST.PP-NA

'[Instead of solving these emotional questions] people eat.'

For passive constructions with intransitive verbs and the auxiliary tikt see Section 6.

The characteristic features of the typical (basic) passive with tikt are summarized in Table 6. 
Table 6. Profile of the Latvian passive with tikt + PST.PP

\begin{tabular}{|c|c|}
\hline Feature & Value \\
\hline Participle & PST.PP \\
\hline Auxiliary & tikt 'become/get' \\
\hline Subject & $>90 \%$ nominative subject \\
\hline Agent & $\begin{array}{l}\text { not expressed; some rare examples with agent } \\
\text { phrase in genitive or prepositional phrase } \\
\text { (stylistically marked) }\end{array}$ \\
\hline Meaning & mostly dynamic passive \\
\hline Verbs (transitivity) & transitive; more rarely intransitive \\
\hline Verbs (semantic) & all kinds \\
\hline Actor & mostly human, mostly indefinite, unspecific \\
\hline Frequency & $\begin{array}{l}\text { high; probably the most frequent passive construc- } \\
\text { tion in Latvian }\end{array}$ \\
\hline Word order & sv and vs about equal \\
\hline Register & $\begin{array}{l}\text { all; slightly preferred in press and academic prose; } \\
\text { relatively disfavoured in fiction }\end{array}$ \\
\hline
\end{tabular}

\section{Constructions with the $m$-participle in Lithuanian and Latvian}

\subsection{Pure passives in Lithuanian: $m$-vs. $t$-passive}

While passive constructions with an auxiliary 'become' are found only in Latvian, the regular use of the $m$-participle in pure passive constructions is a Lithuanian innovation (see Ambrazas 1990, 191-192 for a short history). In this section we give a short insight of its contemporary use, compared to the passive with the $t$-participle. Unless otherwise stated, all examples in this section are from the corpus LithuanianWaC v2, from which we draw Sample 1 and Sample 2 for closer inspection and quantitative analyses, as explained in the Introduction. 
Though the $m$-passive is mostly used by imperfective predicates (in $78 \%$ of the instances according to Geniušienè 2016, 139), it may be formed from verbs of all aspectual classes. As was mentioned before, $m$-passives are always dynamic (actional). While the $t$-participle entails anteriority, the $m$-participle either expresses 'simultaneity or lack of discrete location in time' (Wiemer 2006b, 276). $m$-passives are predominantly used in the present tense. Our analysis of $m$-passives without auxiliary showed that in the absolute majority of cases a present tense auxiliary can be inserted. In the table below we give figures from Geniušienè (2016) and from our Sample 1 (for details about data selection and method see Introduction).

Table 7. m-passives and the category of tense in Lithuanian

\begin{tabular}{l|l|l|l}
\hline \multirow{2}{*}{ Tense } & \multicolumn{2}{|l|}{ Geniušienė $\left(\mathbf{2 0 1 6} \mathbf{1 4}^{7}\right)$} & \multirow{2}{*}{$\begin{array}{l}\text { Sample 1 } \\
\text { (LithuanianWaC v2) }\end{array}$} \\
\cline { 2 - 3 } & $\begin{array}{l}\text { Transitive } \\
\text { verbs }\end{array}$ & $\begin{array}{l}\text { Non-transitive } \\
\text { verbs }\end{array}$ & $71 \%$ \\
\hline No auxiliary & - & - & $11.2 \%$ \\
Present & $70 \%$ & $83 \%$ & $13.5 \%$ \\
Past simple & $23 \%$ & $12 \%$ & $0.7 \%$ \\
Past frequentative & $2 \%$ & $3 \%$ & $3.6 \%$ \\
Future & $5 \%$ & $2 \%$ & $100 \%(303)$ \\
Total & $100 \%(1,160)$ & $100 \%(301)$ &
\end{tabular}

As the absence of the auxiliary with an $m$-passive mostly equals its use in the present tense, the ratio of present tense uses amount to more than $80 \%$ of all examples in our sample. Geniušiene’'s study showed similar results: with transitive and non-transitive verbs the reported incidence of $m$-passives in present tense is $70 \%$ and $83 \%$ respectively.

With respect to tense (especially present and past), the $m$-passive differs clearly from the $t$-passive, as can be seen when comparing Table 7 with Table 8.

\footnotetext{
${ }^{7}$ Geniušienè gives no figures for the ratio of passives with omitted auxiliary in her data. It is therefore unclear whether all cases of omitted auxiliary were automatically counted as present tense uses or whether they were assigned to respective tense forms according to the meaning.
} 
Table 8. t-passives and the category of tense in Lithuanian

\begin{tabular}{|c|c|c|c|}
\hline \multirow[b]{2}{*}{ Tense } & \multicolumn{2}{|c|}{ Geniušienè $(2016,11)$} & \multirow{2}{*}{$\begin{array}{l}\text { Sample } 1 \\
\text { (LithuanianWaC v2) }\end{array}$} \\
\hline & $\begin{array}{l}\text { Transitive } \\
\text { verbs }\end{array}$ & $\begin{array}{l}\text { Non-transitive } \\
\text { verbs }\end{array}$ & \\
\hline No auxiliary & - & - & $43.8 \%$ \\
\hline Present & $59 \%$ & $67 \%$ & $9.1 \%$ \\
\hline Past simple & $37 \%$ & $31 \%$ & $40.7 \%$ \\
\hline Future & $3 \%$ & $2 \%$ & $6.4 \%$ \\
\hline Total & $100 \%^{8}(3,580)$ & $100 \%(289)$ & $100 \%(219)$ \\
\hline
\end{tabular}

In present tense the $m$-passive is used in a habitual-generic sense (30) or in order to describe an ongoing activity or process (31). In the latter case it often has the meaning of progressive aspect.

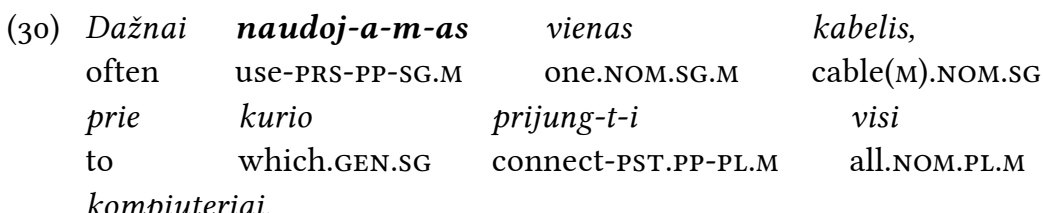
computer(M).NOM.PL

'Often one cable is used which all computers are connected to.'
(31) kai verki-a-nt-is ar kitaip savo when cry-PRS-PA-NOM.SG.M or otherwise RPOSS poreikius reiški-a-nt-is vaikas yra need.ACC.PL express-PRS-PA-NOM.SG.M child(M).NOM.SG be.PRS.3 tévy ignoruoj-a-m-as, stabd-o-m-as parent.GEN.PL ignore-PRS-PP-SG.M stop-PRS-PP-SG.M ar netgi baudži-a-m-as or even punish-PRS-PP-SG.M

'when a child who is crying or otherwise expressing its needs is (constantly) being ignored, stopped or even punished by its parents'

\footnotetext{
${ }^{8}$ Actually, the figures in the column of Transitive verbs sum up to $101 \%$, so there must be a mistake in Geniušienè 2016, 141, table 5.8.
} 
The $m$-passive is often used in various procedural texts (legal documents, rules, instructions, descriptions of how a method works, how things are (being) done etc. (see also 4.3.1).

(32) [Murray'aus metodo esmè tokia:]

$\begin{array}{lcc}\text { iš pradžiu } & \text { iraš-o-m-as } & 15 \text { minučiu } \\ \text { first } & \text { record-PRS-PP-SG.M } & 15 \text { minute.GEN.PL } \\ \text { trukmés } & \text { sutuoktiniu } & \text { pokalbis. } \\ \text { duration.GEN.SG } & \text { spouse.GEN.PL } & \text { talk(M).NOM.SG }\end{array}$

'[The essence of Murray's method is the following:] first a 15 minutes' talk of a couple is recorded.'

Geniušienè \& Nedjalkov (1988, 369-370) call the present passive participle 'imperfective'. Indeed, when a perfective verb is used in the present passive participle form, it gets an imperfective (habitual) reading (see ex. (32), and ex. (33) with past tense auxiliary).

$\begin{array}{llll}\text { (33) } & \text { Buvo } & \text { užpuldinèj-a-m-i } & \text { vietiniai } \\ \text { be.PST.3 } & \text { attack-PRS-PP-PL.M } & \text { native.NOM.PL.M } \\ \text { indènai, } & & \text { kurie } & \text { buvo } \\ \text { American(M).NOM.PL } & \text { who.NOM.PL.M } & \text { be.PST.3 } \\ \text { išstumi-a-m-i } & i s ̌ & \text { gimtuju } \\ \text { push_out-PRS-PP-PL.M } & \text { from } & \text { native.GEN.PL.F.DEF }\end{array}$

žemiu.

land.GEN.PL

'Native Americans were (constantly) being attacked, they were being pushed out of their native lands.'

In (33) the first $m$-passive is formed from a verb with the iterative suffix -ine-which imperfectivizes the prefixed base verb užpulti 'attack'. The second passive predicate does not have such a suffix, but because it is used in the present passive participle form it also gets an imperfective reading, implying that the pushing out of Native Americans from their lands was a gradual process consisting of many recurrent events. Geniušienė (2016, 42) says that when a past tense auxiliary is used with a present passive participle of a perfective verb, it expresses 'an iterative mode of action'.

Analyzing the data we noticed that in texts describing historical facts in a chronological order $m$-passives (with covert present tense auxiliary) are sometimes used instead of $t$-passives (with covert past tense auxiliary). This use has an affinity to historic or narrative present, cf. (34). 
(34) Petras ČıžıKAS gimé $1944 \mathrm{~m}$. mažažemio valstiečio šeimoje. <..>> 1971 m. isstojo $i$ Vilniaus valstybinio universiteto teisés fakultetą. Apkaltintas (PST.PP) šmeižikiškos literatūros, t.y. „LKB Kronikos Nr. 3“ dauginimu, 1973 m. suimamas (PRS.PP), pripažįstamas (PRS.PP) nepakaltinamu ir patalpinamas (PRS.PP) i Černiachovskio spec. psichiatrinę ligoninę. Ten iškalejjęs 4 metus, perkeliamas (PRS.PP) i N. Vilnios respublikine psichiatrinę ligoninę. $1977 \mathrm{~m}$. pripažintas (PST.PP) sveiku.

'Petras Čižikas was born in 1944 in a family of a smallholder. <... In 1971 he entered the Faculty of Law of Vilnius State University. Accused of spreading slanderous literature, that is "The Chronicle of the Lithuanian Catholic Church No. 3", in 1973 he is arrested, declared unsound of mind and placed in Černiachovskis' psychiatric hospital. After for 4 years of imprisonment, he is moved to the psychiatric hospital of Naujoji Vilnia. In 1977 he was declared healthy.'

All the highlighted $m$-passive predicates are formed from perfective verbs, and $t$-passives with past tense auxiliaries could have been used instead. The use of $m$-passives in such contexts seems to create a dramatic effect as if the events unfolded before the eyes of the reader.

$m$-passives with overt oblique agents are quite rare: according to Geniušiene $(2016,147)$ they constitute only $3 \%$ out of 1,540 passive constructions (with $t$-passives, the incidence of overt agents is 7.9\%). Another important generalization is that with $m$-passives the referent of the agent (either overt or covert) is mostly generic or indefinite non-specific, while $t$-passives are predominantly used with specific (known or unknown) agents (Geniušienè 2016, 147, 276; cf. also Lindström et al. 2020, this volume).

As shown in Table 8 above, with $t$-passives the auxiliary is less often omitted than with $m$-participles ( $43.8 \%$ vs. $71 \%$ in our Sample 1). Interestingly, in about half of the cases with omitted auxiliary, a past tense auxiliary can be inserted. Typically, these are cases where the sentence contains an explicit past-tense reference (an adverb, a temporal subordinate clause etc.). All such $t$-passives are dynamic (actional), cf. (35).

(35) Lithuanian

Taivane

Taiwan.LOC

procesas.

process.NOM.SG

tiesiogiai

directly spartejo

accelerate.PST.3

$1996 \mathrm{~m}$.

in_1996

išrink-t-as

elect-PST.PP-SG.M demokratejimo

democratization.GEN.SG

pirma karta

first.ACC.sG.M time(M).ACC.SG

prezidentas.

president(M).NOM.SG 
'In Taiwan the process of democratization accelerated. In 1996 the president was directly elected for the first time.'

We looked through all the examples of omitted auxiliary with a $t$-passive in Sample 1 (see Table 8) and tried to distribute them either to present or past tense uses according to the meaning and context. The result was the following distribution of different tense forms: present tense $27.8 \%$, past tense $56.2 \%$ and future tense $6.4 \%$. About $9.6 \%$ of the examples were ambiguous between present and past tense reference (36).

(36) Lithuanian

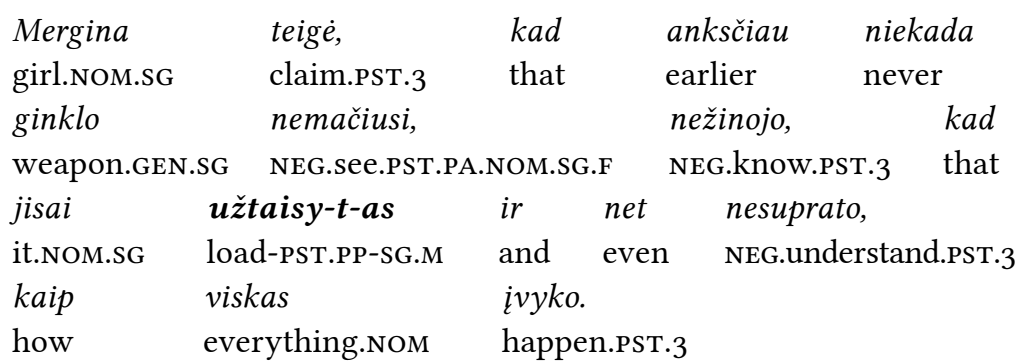

'The girl claimed that she had never seen the weapon before, that she didn't know that it was loaded and that she didn't even understand how everything happened.'

In (36) both forms of the auxiliary would be possible: kad jis yra/buvo užtaisytas 'that it is/was loaded'. As can be seen from Table 8, Geniušienè's figures show that the incidence of present-tense uses with $t$-passives is higher than of past-tense uses, but this may be due to the fact that all cases with omitted auxiliary were automatically counted as present-tense uses, as it is generally assumed that the passive auxiliary can only be omitted in present tense ${ }^{9}$ (cf. Geniušienè 2006, 30, Wiemer 2006b, 276). In our study we found that the auxiliary with a $t$-participle was rather often omitted in a past-tense context where it would be incorrect to assume omission of a present-tense auxiliary.

Lastly, we would like to comment on the overall frequency of passives based on the present and past passive participles. Previous research showed that predicates with $t$-participle and $m$-participle differ in frequency, ac-

\footnotetext{
${ }^{9}$ Cf. also Geniušienè's statement: "In the past and future tenses the omission of the auxiliary verb is possible only with the second and subsequent predicates in a chain of verbs, where the auxiliary of the first verb is understood to be shared with the other verbs" $(2016,143)$.
} 
counting for $72.6 \%$ and $27.4 \%$ of passive forms respectively (Geniušienè 2006, 30). These figures are based on data collected mainly from fiction texts. However, in our Sample 1, the ratio of $t$-and $m$-participles was $44 \%$ and $56 \%$ respectively, and in Sample 2, which served as a control sample, it was similar: $48.2 \%$ of $t$-participles and $51.8 \%$ of $m$-participles. The difference between Geniušienè's and our results indicates that the frequency of $m$-and $t$-passives may vary considerably in texts depending on the register.

\subsection{Subject impersonals in Lithuanian}

The literature on the Lithuanian passive mentions the possibility of forming impersonal passives of transitive verbs with retained accusative objects (Ambrazas et al. 2006, 661; Geniušienė 2006, 38, Geniušienè 2016, 121). Examples of $m$-participles in the non-agreement form are usually given to illustrate this construction, cf. (37).

(37) Lithuanian (cited from Spraunienè et al. 2015, 340)

$\begin{array}{llll}\text { I } & \text { Lietuva } & \text { daugiausia } & \text { vež- } \boldsymbol{a}-\boldsymbol{m} \text { - } \boldsymbol{a} \\ \text { to } & \text { Lithuania.ACC } & \text { mostly } & \text { ship-PRs-PP-NA } \\ \text { itin } & \text { mažos } & \text { tūrio } & \text { masės, } \\ \text { very little.GEN.SG.F } & \text { volume.GEN.SG } & \text { weight.GEN.SG } \\ \text { susispaudžiančiq } & \text { stiklo } & \text { vatą. } \\ \text { compressible.ACC.SG.F } & \text { glass.GEN.SG } & \text { wool.ACC.SG }\end{array}$

'Mostly compressible glass wool (ACC) of very low volumetric weight is shipped to Lithuania.'

Ambrazas (2006, 661) observes that such non-agreeing passives do not contain an agentive genitive. Geniušiene $(2006,45)$ says that she has found several attestations of such constructions in her corpus but that they are used very rarely. According to Geniušiene $(2016,121)$ the functional motivation for using such agentless subjectless passives of transitive verbs with non-promoted objects is 'to lend prominence to the action or the genericity of the agent'. Consequently, they exhibit the following formal and semantic features: the passive predicate is used in present tense, the non-promoted object occurs postverbally and a generic agent is implied (ibid., 123). Wiemer (following Plungian) treats such constructions as 'subject impersonals' characterized by 'syntactic suppression' rather than demotion of the highest-ranking argument (Wiemer, forthcoming). A similar distinction between passive and impersonal voices is presented in Blevins (2003). Although Wiemer admits that "[i]n Lithuanian, subject 
impersonal and impersonal passive are practically indistinguishable" (Wiemer, forthcoming), cases with retained accusative objects like (37) could be regarded as subject impersonals par excellence. In a small corpus investigation ${ }^{10}$ we found that accusative objects are more likely to appear with one verb class, namely, unprefixed reflexive verbs. Passive forms of unprefixed reflexive forms are peculiar in that they can only be used in the non-agreement form - the agreeing passive is blocked by the wordfinal reflexive suffix. With some of these verbs the accusative seems to freely alternate with the nominative, cf. $(38,39)$.

(38) Lithuanian (ltTenTen14)

$\begin{array}{lll}\text { Taigi } & \text { mezgasi } & \text { diskusija, } \\ \text { so } & \text { develop.PRS.3.RFL } & \text { discussion.NOM.SG }\end{array}$

aiškin-a-m-a-si santyki-ai.

clarify-PRS-PP-NA-RFL relation-NOM.PL

'So a discussion develops, relations are being clarified.'

(39) Lithuanian (DLKT)

Dabar

šūviais

nowadays

shot.INS.PL

daugiausia

aiškin-a-m-a-si

turtinius

mostly

clarify-PRS-PP-NA-RFL

proprietary.ACC.PL

santyki-us.

'Nowadays people deal with proprietary relations with the help of shots.' (a closer translation with a passive construction would be: 'Nowadays proprietary relations are mostly being dealt with by shots.')

In (40) the same passive form of the reflexive verb rinktis 'choose (for oneself)' is used twice, first with a promoted nominative subject, the second time with a non-promoted accusative object:

(40) Lithuanian (ltTenTen14)

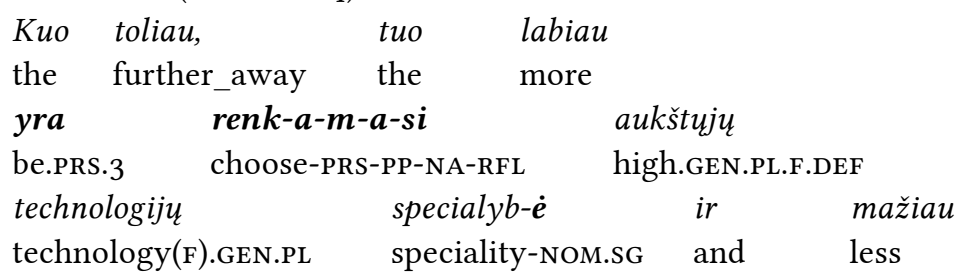

${ }^{10}$ In the corpus.vdu.lt, a search for non-agreement passive forms of reflexive verbs was performed, CQL Vgpp--npnn-y-p, total number of results 42170 , the first 8000 were looked through. Several examples with accusative objects were found, e.g. with aiškintis 'clarify', rinktis 'choose (for oneself)'. In order to get more examples, a search for passive forms of the two reflexive verbs, aiškintis and rinktis was performed in ltTenTen14. 


\begin{tabular}{lll} 
renk-a-m-a-si & \multicolumn{1}{c}{ iprast-as } & \multicolumn{1}{c}{ bendrosios } \\
choose-PRS-PP-NA-RFL & usual-ACC.PL.F & general.GEN.SG.F.DEF \\
klinikinés & praktikos & specialyb-es. \\
clinical.GEN.SG & practise.GEN.SG & speciality(F)-ACC.PL
\end{tabular}

'The further away the more one is inclined to choose a high technology speciality (NOM) rather than to choose the usual general clinical practice specialities (ACC).

In order to get a clearer picture of the frequency of subject impersonals with non-prefixed reflexives, an investigation of the passive forms of the verbs rinktis 'choose (for oneself)' and aiškintis 'clarify' in the corpus ltTenTen14 was carried out. The results are presented in Table 9.

Table 9. Frequency of subject impersonals with accusative objects

\begin{tabular}{l|l|l}
\hline verbal lexeme & rinktis 'choose' & aiškintis 'clarify' \\
\hline Passives with nominative subjects & $51.9 \%(276)$ & $94.9 \%(186)$ \\
Passives with accusative objects & $\mathbf{4 8 . 1 \% ( 2 5 6 )}$ & $\mathbf{5 . 1 \% ( 1 1 )}$ \\
Total & $100 \%(532)$ & $100 \%(197)$
\end{tabular}

As evident from Table 9, subject impersonals with accusative objects from non-prefixed reflexives are by no means rare: they are well attested in the corpus data. However, their frequency with the two verbs is remarkably different: with rinktis 'choose (for oneself)' the accusative marking is nearly as frequent as the nominative, while with aiškintis 'clarify' the nominative marking prevails. We noticed also that the accusative objects can also be preverbal (topical), as in (41).

(41) Lithuanian (ltTenTen14)

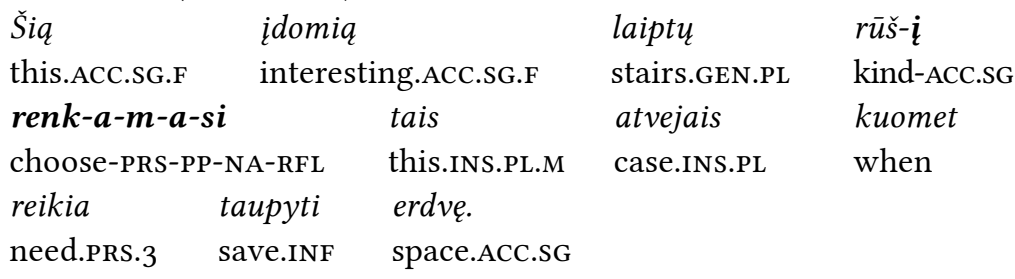

'This interesting kind of stairs is chosen when one needs to save space.'

Our small investigation suggests that subject impersonals are spreading within the domain of reflexive verbs. More research is required though in 
order to determine which factors govern the distribution of accusative vs. nominative in such constructions. Nevertheless, the data we have found is sufficient to include subject impersonal into the passive family of Lithuanian. The profile of this construction is given in Table 10.

Table 10. Profile of the Lithuanian Subject Impersonal

\begin{tabular}{ll} 
Feature & Value \\
\hline Participle & PRS.PP (occasionally PST.PP) \\
\hline Auxiliary & 'be', optional \\
Subject & $\begin{array}{l}\text { non-promoted direct object alternates with } \\
\text { nominative subject }\end{array}$ \\
\hline Agent & not expressed \\
\hline Meaning & present habitual \\
\hline Verbs & transitive; mostly reflexives ${ }^{11}$ \\
\hline Tense & present \\
\hline Actor & generic \\
\hline Frequency & varies depending on the verbal lexeme \\
\hline Word order & various \\
\hline Register & media, academic etc.
\end{tabular}

\subsection{Generic and modal constructions with the $m$-participle}

In both Latvian and Lithuanian, constructions with the $m$-participle may have a modal meaning, which may be more or less strongly associated with either possibility or necessity. In Lithuanian, this type is not clearly distinguishable from other predicative uses of the $m$-participle,

${ }^{11}$ More research is required in order to determine the lexical input of the subject impersonal. 
and modal meanings seem to arise largely as implicatures in contexts favouring an interpretation of necessity or possibility. In Latvian, on the other hand, this type of construction is the only passive construction with the $m$-participle, and it is linked more closely to non-predicative uses of this participle than to other members of the passive family.

\subsubsection{Lithuanian: from generic to modal}

The type of construction which we consider in this section is characterized by the following features in Lithuanian:

- it contains the $m$-participle;

- it is found with both transitive and intransitive verbs, including reflexive verbs;

- the rules for agreement are the same as with the basic passive;

- the participle is used either alone or with a form of the auxiliary būti 'be';

- an agent phrase is not possible;

- the deleted actor has to be human;

- the meaning ranges from general statements about what people (tend to) do through vague modal meanings to interpretations as explicitly expressing necessity or possibility.

For a quantitative analysis we used our two samples from the corpus Lithuanian $\mathrm{WaC}$ v2. Sample 1 contains 339 clauses with an $m$-participle as predicate, and $38(11.2 \%)$ observations represent the modal passive. In Sample 2 with $354 \mathrm{~m}$-passives, 29 instances of the modal construction were identified (8.2\%). These figures give only a rough idea about the frequency of the construction, because it was not always possible to determine the construction type of a particular construct.

The construction is used in statements about the observed behaviour of people in general, as in (42). It is neutral with respect to speaker inclusion.

(42) Lithuanian (DLKT)

\begin{tabular}{llrl} 
Vis & dažniau & \multicolumn{1}{c}{ at-si-skait-o-m- $\boldsymbol{a}$} \\
PTC & often.COMP & PVB-RFL-pay-PRS-PP-NA \\
kredito & kortelemis. \\
credit.GEN.SG & card.INS.PL
\end{tabular}

'More and more often people pay with credit cards.' 
The modal meaning that arises may be necessity (43) or possibility (44).

(43) Lithuanian (DLKT)

Likviduoj-a-nt banka, pirmiausia

liquidate-PRS-CVB bank.ACC.SG first

at-si-skait-o-m-a su banko indelininkais

PVB-RFL-pay-PRS-PP-NA with bank.GEN.SG depositors.INS.PL

'When liquidating a bank, the bank depositors are (to be) paid first.'

(44) Lithuanian (DLKT)

Ap-si-kreči-a-m-a

per maista,

PVB-RFL-infect-PRS-PP-NA

through food.Acc.sG

vandeni,

neplautas

rankas.

water.ACc.SG

unwashed.AcC.PL hands.ACC.PL

'One may get infected through food, water, unwashed hands.'

Note that the verb apsikrèsti 'get infected' can only be used in an $m$ passive with the possibility meaning. The necessity meaning is blocked due to the fact that the verb denotes an involuntary action.

To a large degree, it is the extralinguistic context that determines the modal interpretation of a construction with the $m$-participle. An important factor that triggers the necessity reading is register, more specifically the register-specific communicative function of the text. If (43) is part of a regulation about liquidating banks, it will be understood as a directive. We find the meaning of necessity therefore most often in registers such as laws and regulations (cf. Vladarskienè 2004, 71), and various kinds of instructions. The clearer the 'instructing' intention of the text is, and the greater the number of details given, the clearer the meaning of necessity appears to be. Examples (45) and (46) can hardly be understood as neutral descriptions of behaviour. Adverbial phrases specifying the manner or length or frequency of carrying out the action contribute to the modal (necessity) interpretation.

(45) Lithuanian (DLKT)

$\begin{array}{llll}\text { Korta } & \text { pild-o-m-a } & \text { tiksliai } & \text { ir } \\ \text { card.NOM.SG } & \text { fill_in-PRS-PP-SG.F } & \text { accurately } & \text { and } \\ \text { iskaitomai } & \text { spausdintinemis } & \text { raidemis. } & \\ \text { legibly } & \text { block.INS.PL } & \text { letters.INS.PL } & \end{array}$

'The card is (to be) filled in accurately and legibly in block letters.'

(46) Lithuanian (DLKT)

Vonioje iš-būn-a-m-a 20-25 min. kas trečia diena, 
bath.LOC.SG PVB-be-PRS-PP-NA 20-25 min. every_third_day

gyd-o-m-a-si 2-3 ménesius.

treat-PRS-PP-NA-RFL 2-3 month.ACC.PL

'You have to stay $20-25 \mathrm{~min}$. in the bath every three days, and the treatment has to last 2-3 months.'

Two more specialized registers where the use of the $m$-participle for giving instructions seems to be highly conventionalized are sport instructions (47) and cooking recipes (48).

(47) Lithuanian (DLKT)

$\begin{array}{llll}\text { At-si-gul-a-m-a} & \text { ant } & \text { nugaros. } & \text { Kojos } \\ \text { PVB-RFL-lie_down-PRS-PP-NA } & \text { on } & \text { back.GEN.SG } & \text { leg(F).NOM.PL } \\ \text { su-lenk-t-os } & \text { per } & \text { kelius } & \\ \text { PVB-bend-PST.PP-NOM.PL.F } & \text { over } & \text { knee.ACC.PL } & \\ 90 \quad \text { laipsniu. } & & & \\ 90 \quad \text { degrees.GEN.PL } & & & \end{array}$

'You have to lie down on your back. The legs are bent over the knees at a 90-degree angle.' (= 'Lie down on your back.')

(48) Lithuanian (DLKT)

\begin{tabular}{|c|c|c|c|}
\hline $\begin{array}{l}\text { Pa-sūd-o-m-a, } \\
\text { PVB-salt-PRS-PP-NA }\end{array}$ & \multicolumn{2}{|c|}{$\begin{array}{l}\boldsymbol{i} \text {-beri-a-m-a } \\
\text { PVB-pour-PRS-PP-NA }\end{array}$} & \multirow[t]{2}{*}{$\begin{array}{l}\text { pipiru } \\
\text { pepper.GEN.PL }\end{array}$} \\
\hline verd-a-m-a & $5 \mathrm{~min}$. & Su-ded-a-m- & \\
\hline cook-PRS-PP-NA & $5 \mathrm{~min}$. & \multicolumn{2}{|c|}{ PVB-put_in-PRS-PP-PL.F } \\
\hline midij-os & \multicolumn{2}{|c|}{$u \check{z}$-dary-t-omis } & kriauklelemis \\
\hline mussel(F)-NOM.PL & \multicolumn{2}{|c|}{ PVB-close-PST.PP-INS.PL.F } & shell(F).INS.PL \\
\hline lètai & \multicolumn{2}{|c|}{$u \check{z}$-verd-a-m-a. } & \\
\hline slowly & \multicolumn{2}{|c|}{ PVB-boil-PRS-PP-NA } & \\
\hline
\end{tabular}

'Add salt, pour pepper in, and cook for 5 minutes. Put in the mussels with closed shells and slowly bring to a boil.'

The necessity meaning of $m$-passives in directives ('what you have to do') arises from the habitual-generic meaning ('what people usually do') which these forms often have in the present tense. A conceptual link between habitual and potential may give rise to a meaning of possibility: what is usually done can be done (49).
(49) Bruknès
lapu
arbata
vartoj-a-m-a
cow_berry.gEN.sG
leaf.GEN.PL
tea(F).NOM.SG
use-PRS-PP-SG.F
serg- $a-n t$
cukralige.
be_ill-pRs-cvi
diabetes.INs
'Cow-berry leaf tea is used to treat diabetes.' Implies: 'can be used' 
In addition, there may be lexical cues that trigger a possibility reading. Here to mention are adverbs which indicate the feasibility of an action such as greitai 'quickly', lengvai 'easily', sunkiai 'with difficulty'.

(50) Lithuanian (DLKT)

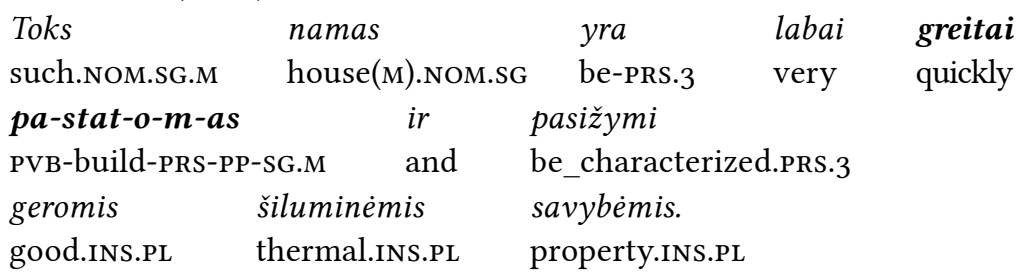

'Such a house is (= can be) built very quickly and has good thermal properties.'

(51) Lithuanian (DLKT)

\begin{tabular}{llll} 
Tiesa, & \multicolumn{1}{c}{ šis } & lobis & buv-o \\
true & DEM.NOM.SG.M & treasure(M).NOM.SG & be-PST.3 \\
lengvai & $\begin{aligned} \text { rand-a-m-as. } \\
\text { easily }\end{aligned}$ & find-PRS-PP-SG.M & \\
end &
\end{tabular}

'True, this treasure was easy to find.' = 'could be easily found'

Finally, particular lexical groups of verbs may be specialized for a particular modal meaning. The $m$-participles of verbs of perception are always understood in the meaning of possibility; their translation equivalents in English are adjectives such as visible, audible. Examples of such verbs are (pa)matyti 'see', regèti 'see', pastebèti 'notice', išvysti 'see', girdetti 'hear', jausti 'feel', nujausti 'anticipate', jžvelgti 'perceive', suprasti 'understand', suvokti 'realize', užuosti 'smell'. See examples (52) and (53).

(52) Lithuanian (DLKT)

Žodis buv-o vos gird-i-m-as.

word(M).NOM.SG be-PST.3 barely hear-PRS-PP-SG.M

'The word was barely audible.'

(53) Lithuanian (DLKT)

Fupiteris beveik visa nakti bus

PN.NOM almost all.ACC.SG night.ACC.SG be.FUT.3

$\begin{array}{lll}\text { mat-o-m-as } & \text { Dvynių } & \check{z} \text { vaigždyne. } \\ \text { see-PRS-PP-SG.M } & \text { PN.GEN } & \text { constellation.LOC.SG }\end{array}$

'Jupiter will be visible in the constellation of Gemini almost all night.'

It has to be noted that $m$-passives with adverbs describing feasibility of an action and $m$-passives derived from verbs of perception clearly fall 
apart from the rest of the modal uses of $m$-participles in that they are used with an auxiliary, while in the rest of the modal passives the auxiliary is normally omitted (and only a present tense auxiliary may be used). If a past tense auxiliary were used in such examples as (43), the modal meaning would be lost, and the sentence would only have a modality-neutral meaning (i.e. refer to a past event). However, the use of a past tense auxiliary in (51) or (52) by no means cancels the modal meaning.

\subsubsection{Latvian: two modal constructions}

As stated above, Latvian constructions with an $m$-participle as the predicate are always modal, though the modal meaning may be vague. This specialization may be connected to the grammaticalization of another construction as a pure passive: the auxiliary tikt in combination with the past passive participle (see Section 3). The construction with tikt is also used in generic-habitual clauses where Lithuanian uses the $m$-participle (54).

(54) Latvian (lvTenTen14)

\begin{tabular}{|c|c|c|c|c|}
\hline \multirow{2}{*}{$\check{S} \bar{l}$} & & & tiek & \multirow{2}{*}{$\begin{array}{l}\text { lietota } \\
\text { use.PST.PP.SG.F }\end{array}$} \\
\hline & M.SG.F & $\begin{array}{l}\text { teja } \\
\text { tee.NOM.sG }\end{array}$ & AUX.PRS.3 & \\
\hline lai & nomāktu & ape & & \\
\hline & suppress.IRR & app & ACC.SG & \\
\hline
\end{tabular}

More typical in this function is the use of a third person active form (55).

(55) Latvian (lvTenTen14)

\begin{tabular}{llll} 
visplašāk & \multicolumn{1}{c}{ pelašķu } & tēju & lieto \\
most_widely & yarrow.GEN.PL & tea.ACC.SG & use.PRs.3 \\
pret & saaukstēšanos & \\
against & cold.ACC.SG & \\
'Yarrow tea is most widely used to treat a cold.'
\end{tabular}

Examples (54) and (55) are neutral descriptions of habitual behaviour. A construction with the $m$-participle, though seemingly similar, always contains deontic modality, either possibility (56) or necessity (57).

(56) Latvian (LVK2018)

$\begin{array}{lccc}\text { Patlaban } & \text { «Android» } & \text { ir } & \text { lietoj-am-a } \\ \text { currently } & \text { Android } & \text { be.PRS.3 use-PRS.PP-SG.F } \\ \text { tikai } & \text { mobilajos } & \text { tālrunos. } \\ \text { only } & \text { mobile.LOC.PL.M } & \text { telephone.LOC.PL } \\ \text { 'At present } & \text { Android can be used only in mobile phones.' }\end{array}$


(57) Latvian (lvTenTen14)

$\begin{array}{lcll}\begin{array}{l}\text { Kardamons } \\ \text { cardamom.NOM.SG }\end{array} & \begin{array}{l}\text { lietoj-am-s } \\ \text { use-PRS.PP-SG.M }\end{array} & \begin{array}{l}\text { loti } \\ \text { very }\end{array} & \begin{array}{l}\text { mazos } \\ \text { small.LOC.PL }\end{array} \\ \begin{array}{l}\text { daudzumos. } \\ \text { quantity.LOC.PL }\end{array} & & \\ \text { 'Cardamom has to be used in very small doses.' } & \end{array}$

At least from a synchronic point of view, in Latvian the modal meanings of the participle cannot be linked to a generic base meaning, but are conventionalized (grammaticalized). This conventionalization is also described in reference grammars of Latvian (MLLVG I, 645).

While in both languages we note the meanings of necessity and possibility, the contexts in which these meanings most typically arise only partially overlap. In Latvian, the impact of functional characteristics of registers may be smaller than in Lithuanian. The $m$-participle is not used in procedural texts, where the preferred forms are third person active (for example, in recipes) and second person imperative (for example, in sports instructions). The participle is however typical for legal texts (58). This is a parallel to Lithuanian, but also shows its stronger connection to obligation.

(58) Latvian (LVK2018)

\begin{tabular}{|c|c|c|}
\hline $\begin{array}{l}\text { Sastād-ot } \\
\text { compile-cvB }\end{array}$ & $\begin{array}{l}\text { mantojum- } a \\
\text { inheritance-GEN.SG }\end{array}$ & $\begin{array}{l}\text { sarakst-u, } \\
\text { list-ACC.sG }\end{array}$ \\
\hline Civilproces- $a$ & likum-am & rakst-ām-s \\
\hline $\begin{array}{l}\text { Civil_process-GEN.S } \\
a k t-s . \\
\text { deed-NOM.SG }\end{array}$ & law-DAT.SG & write-PRS.PP-NOM.SG.M \\
\hline
\end{tabular}

As in Lithuanian, the meaning of possibility often, though not always, arises with adverbs that evaluate the feasibility of the activity (viegli 'simply', grūti 'hard').

Individual lexemes as well as lexical-semantic groups of verbs may show a preference for either necessity or possibility. As in Lithuanian, with verbs of perception the participle expresses possibility-this is the rule with involuntary perception (redzams 'visible', dzirdams 'audible') and a strong tendency with voluntary perception (skatāms 'to be looked at'). The $m$-participle of the verb darit, on the other hand, is almost always 
used in the meaning 'is to do, has to be done', and not in the meaning 'doable' (59). In general, there is a correlation between agentivity and necessity: the more agentive verbs express necessity rather than possibility, and with less agentive verbs (with involuntary actors), possibility is the preferred reading.

(59) Latvian (lvTenTen14)

$\begin{array}{llll}\text { Arī } & \text { režisori } & \text { zina, } & \text { kas } \\ \text { also } & \text { director.NOM.PL } & \text { know.PRS.3 } & \text { what.NOM } \\ \text { viņiem } & \text { darāms. } & & \\ \text { 3.DAT.PL } & \text { do.PRS.PP.SG.M } & & \end{array}$

'The directors also know what they have to do.' (Not: 'what they can do')

Example (59) shows a typical pattern of the participle darāms 'to be done', where it is combined with the pronoun kas 'what', 'something' and an argument in the dative expressing the actor, or rather: the person for whom the activity is necessary. This dative is reminiscent of the 'dative of agent' in constructions with the gerundive in Latin (6o).

(60) Latin (cited from Taylor 2017, 72; glosses added)

$\begin{array}{llll}\text { urbs } & \text { nobis } & \text { delenda } & \text { est } \\ \text { city.NOM.SG } & \text { 1PL.DAT } & \text { destroy.GDV.SG.F } & \text { be.PRS.3SG }\end{array}$

'The city must be destroyed by us'; literal translation given by Taylor: 'The city is, for us, a needing-to-be-destroyed one.'

In Latvian, the use of such a dative is however quite restricted. It is attested only with a few verbs and most often in combination with the pronoun kas 'what, something' as a subject, as in (59). Besides darīt 'do', it is mostly verbs of speaking that appear with a dative, most often sacit 'say' (man ir kas sakāms 'I have something to say', 'I need to say something'), but also vaicāt 'ask', piebilst 'add'. Even more idiomatic are constructions with the $m$-participle of meklet 'search' in either interrogative or negated clauses, as in (61). These constructions have an exact parallel in German and may have arisen as calques (German Du hast hier nichts $z u$ suchen, literally 'you don't have anything to search here' = 'you have no reason for being here'; Was hast du hier zu suchen? literally 'What do you have to search here?' = 'What are you doing here?').

(61) Latvian (LVK2018)

$\begin{array}{lllll}\text { Šeit } & n u & \text { tev } & \text { nekas } & \text { nav } \\ \text { here } & \text { PTC } & \text { 2SG.DAT } & \text { nothing.NOM } & \text { NEG.be.PRS.3 }\end{array}$




\section{meklējams!}

search.PRS.PP.SG.M

'You have no business to be here!'

The modal construction with the $m$-participle is also found with intransitive verbs. According to Holvoet $(2007,51)$, this shows a further step in the grammaticalization of an impersonal modal construction, more precisely, of a construction expressing necessity, as he observes a narrowing of the potentially twofold meaning to necessity with intransitive verbs. Furthermore, he states that "at this stage, the construction is not copular anymore" $(2007,51)$. Some additions may be made to these important observations. Different kinds of intransitive verbs seem to differ with respect to the points raised by Holvoet (specialization to necessity and status as copular constructions). The intransitive verbs most frequently found in this construction are verbs of voluntary movement, especially iet 'go on foot', braukt 'go by transport', skriet 'run'. In the construction, these verbs however usually appear with an object raised to subject (as in 62), or with an element oscillating between object and adverbial, which may or may not be raised to subject, such as a phrase referring to the way (ejams garš celšs 'one has to go (for) a long way'), the distance (ejams $8 \mathrm{~km}$ 'one has to go for $8 \mathrm{~km}$ '), the duration (ejams trîs stundas 'one has to go for three hours'), the direction, goal, or other types. A dative argument is often found in this type of construction.

(62) Latvian (lvTenTen14)

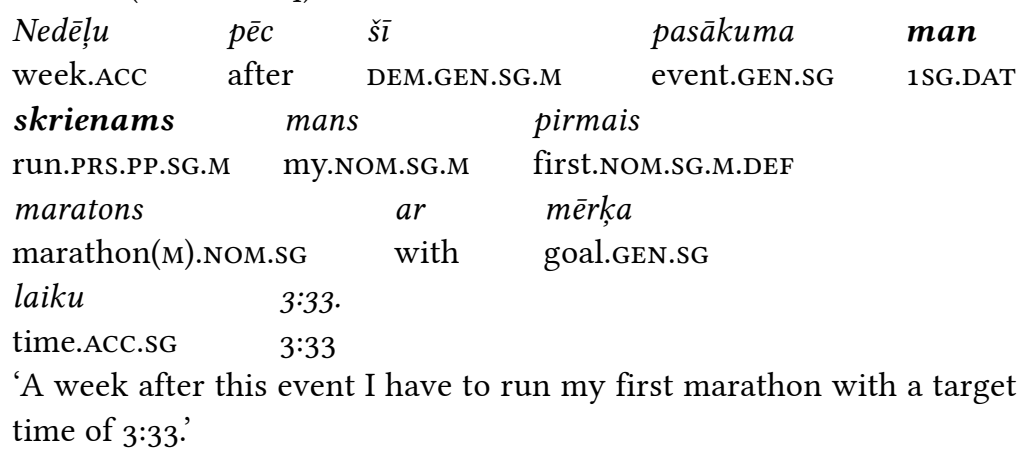

There are no examples in the corpora where the construction would express purely the necessity of carrying out the activity expressed by an intransitive verb, such as 'I have to go now', or 'I had to run to catch the bus'. Furthermore, the $m$-participles of the mentioned verbs of motion as 
well as of other intransitive verbs are often found in a predicative use which is not a passive construction, as the noun they relate to does not correspond to the object in an active construction; its semantic role is not patient, but path (63) or instrument. ${ }^{12}$ In this case we rather have a copular construction, and the modal meaning usually is possibility.

(63) Latvian (lvTenTen14)

$\begin{array}{llll}\text { Brīvības } & \text { ielas } & \text { veloceliņš } & \text { ir } \\ \text { PLN } & \text { street.GEN.SG } & \text { cycle_lane.NOM.SG } & \text { be.PRS.3 } \\ \text { forši } & \text { skrienams. } & & \\ \text { fine } & \text { run.PRS.PP.SG.M } & & \\ \end{array}$

'The cycle-lane of Brīvības street is fine to run along / fine for running.'

Here, the participles behave like predicative adjectives; they may be combined with other adjectives and appear in the comparative. They are also used attributively (viegli skrienama taka 'a path easy to run along'), but the predicative use is much more frequent. We may distinguish the copular construction as in (63) from the more verbal passive construction expressing necessity in (62), (61) and (57-59). The copular construction is found with further intransitive verbs that do not appear in the passive construction $(64,65)$.

(64) Latvian (lvTenTen14)

$\begin{array}{llll}\text { tas } & \text { ir } & \text { loti } & \bar{e} r t i \\ \text { DEM.NOM.SG.M } & \text { be.PRS.3 } & \text { very } & \text { comfortably } \\ \text { guḷams. } & & & \\ \text { sleep.PRS.PP.SG.M } & & & \end{array}$

(Talking about a children's pushchair:) 'It is very comfortable for sleeping / to sleep in.'

(65) Latvian (lvTenTen14)

Nemiers $[\ldots] \quad$ nav smejams.

anxiety.NOM.SG NEG.be.PRS.3 laugh.PRS.PP.SG.M

'Anxiety is not to be laughed about.'

To sum up, in Latvian two or more constructions may be distinguished where the $m$-participle is used as the predicate of a clause:

${ }^{12}$ The vehicle expressing the instrument of the verb braukt 'go by transport' may be the object of an active clause (braukt mašinn 'drive a car'), but more often it is an oblique phrase (braukt ar mašīnu 'go by car'). 
A more passive-like construction where the subject corresponds to the patient of the verb; this construction has a modal meaning which may be either possibility or necessity, and is typical only for transitive verbs.

A subtype of the above or another type: a passive-like construction expressing necessity, where the person obliged or expected to carry out the action may be added in the dative. This type is found with agentive transitive and intransitive verbs, but seems to be lexically restricted and not fully conventionalized: It most often appears with the verb darit 'do', verbs of saying, and verbs of voluntary motion. Some uses are idiomatic. The construction is not always clearly distinguishable from the one described before and the following.

A copula construction where the subject can have various semantic roles, including patient, instrument, theme, path, and others. The participle behaves like an adjective: it may have the comparative suffix, or the negative prefix, and be combined with other adjectives. Both transitive and intransitive verbs are used in this construction, usually verbs characterized by low agentivity and volitionality of the actor, for example, verbs of involuntary perception. The modal meaning is often vague, or it is possibility rather than necessity. The participles that are primarily used in this and not the other construction tend to lexicalize.

\subsubsection{Summary}

We agree with Holvoet $(2007,51)$ that the modal meaning of $m$-participles is conventionalized only in Latvian, and that in Lithuanian one cannot speak of a modal construction. However, we do not agree that the combination of be and the $m$-participle is "without any modal meaning" in Lithuanian (Holvoet 2007, 51). In corpora of Modern Standard Lithuanian we found that modal meanings regularly arise in certain contexts. The meaning of necessity is mainly triggered by the communicative function of the register: it is conventionalized in cooking recipes, sports instructions and legal acts. It appears only in present tense (with deleted auxiliary). Possibility is most clearly observed with verbs of perception, or when the predicate is modified by an adverb meaning 'easily', 'quickly', 'with difficulties', or the like. Such constructions may be used in present and past tense. Otherwise, modal meanings mostly arise as implicatures from the generic-habitual meaning that $m$-passives often have. 
In Latvian, the $m$-participle is not used in generic-habitual meaning, but a meaning of possibility is found in cases similar to Lithuanian. A further parallel is the more conventionalized use of the $m$-participle expressing necessity in legal texts (but not in recipes and rarely in other instructions). In general, in Latvian the $m$-participle as a predicate (with or without auxiliary) is used with a vague modal meaning, which is sharpened to either necessity or possibility by contextual, lexical and grammatical features. A special subtype may be singled out which is specialized for necessity and may include the person obligated in the form of a dative. This construction resembles necessitive constructions in Latin and Finnish. In Latvian it is more idiomatic: it is attested only with a limited number of verbs and often has a stylistic flavour (more colloquial, a bit old fashioned). We did not find that it has advanced much on the way that Holvoet $(2007,51)$ suggested, namely, spreading to intransitive verbs in general. With intransitive verbs, another construction is more often found, which is not specialized for necessity and where the participle behaves like an adjective in a copula construction.

Tables 11 and 12 present the profiles of the constructions (without the last mentioned copula construction).

Table 11. Lithuanian $\mathrm{m}$-passive with modal meanings

\begin{tabular}{ll} 
Feature & Value \\
\hline Participle & PRS.PP ( $m$-participle) \\
\hline Auxiliary, tense & $\begin{array}{l}\text { usully no auxiliary and present tense meaning; } \\
\text { passives of perception verbs permit auxiliary } \\
\text { of all tenses }\end{array}$ \\
\hline Actor & human \\
\hline Agent phrase & not possible \\
\hline Meaning & generic, habitual; possibility, necessity \\
\hline Verbs & transitive and intransitive; agentive and non-agentive \\
\hline Word order & follows general word order rules \\
\hline Registers & all; necessity meaning typical for certain registers \\
\hline
\end{tabular}


Table 12. Latvian modal constructions with the m-participle

\begin{tabular}{|c|c|c|}
\hline Feature & Type (i) & Subtype \\
\hline Participle & PRS.PP ( $m$-participle) & PRS.PP ( $m$-participle) \\
\hline Auxiliary & 'be', or no auxiliary & 'be', or no auxiliary \\
\hline Actor & human & human \\
\hline Agent phrase & no & $\begin{array}{l}\text { actor / affected person can be } \\
\text { expressed as a dative phrase }\end{array}$ \\
\hline Meaning & $\begin{array}{l}\text { possibility, necessity; } \\
\text { vague modal meaning }\end{array}$ & necessity \\
\hline Verbs (transitivity) & transitive & $\begin{array}{l}\text { transitive; some intransitive } \\
\text { verbs (voluntary motion) }\end{array}$ \\
\hline Verbs (semantic) & broad range & agentive, voluntary action \\
\hline Word order & various & $\begin{array}{l}\text { participle usually clause- } \\
\text { finally }\end{array}$ \\
\hline Tense, mood & various & $\begin{array}{l}\text { mainly present tense or } \\
\text { conditional, rarely past } \\
\text { tense }\end{array}$ \\
\hline Registers & $\begin{array}{l}\text { all; in the meaning of } \\
\text { necessity typical for } \\
\text { legal texts }\end{array}$ & $\begin{array}{l}\text { typically found in fiction } \\
\text { and in colloquial registers }\end{array}$ \\
\hline
\end{tabular}

\section{Stative passives}

\subsection{Stative passive or resultative proper}

According to Nedjalkov \& Jaxontov (1988, 17), the DYNAmic (ACTIONAL) PASSIVE involves a change in diathesis (agent demotion, patient promotion), but not in the denotational meaning, i.e. a passive construction has the same denotational meaning as the corresponding active construction. The STATIVE PASSIVE or, in their terminology, oBjective RESUlTATIVE is different in this respect in that it implies both a state and an event which the state has resulted from (ibid., 6). A stative passive thus conveys an additional meaning compared to the corresponding active construction, 
cf. Mother cooked the soup - The soup is cooked. The subject of a stative passive is both the patient of the previous event and the holder of the resulting state.

In Baltic languages a stative passive is formed by a $t$-participle combined with an auxiliary 'be'. In both languages the auxiliary 'be' is not obligatory; its absence is mostly equivalent to its use in present tense. In Latvian it appears more often than in Lithuanian. While in Latvian the stative passive is formally differentiated from the actional passive, which is formed with the auxiliary tikt (cf. Section 3), in Lithuanian a $t$-passive may both have a dynamic and a resultative reading. As in many other languages, the stative passive in Baltic interacts with the perfect (of the passive). Constructs with an auxiliary 'be' and a past passive participle may thus have various meanings - they may represent a stative or a dynamic passive, express resultative or perfect, and various tenses and temporal nuances. The following examples give a first illustration.

Examples from the parallel corpus (LiLa)

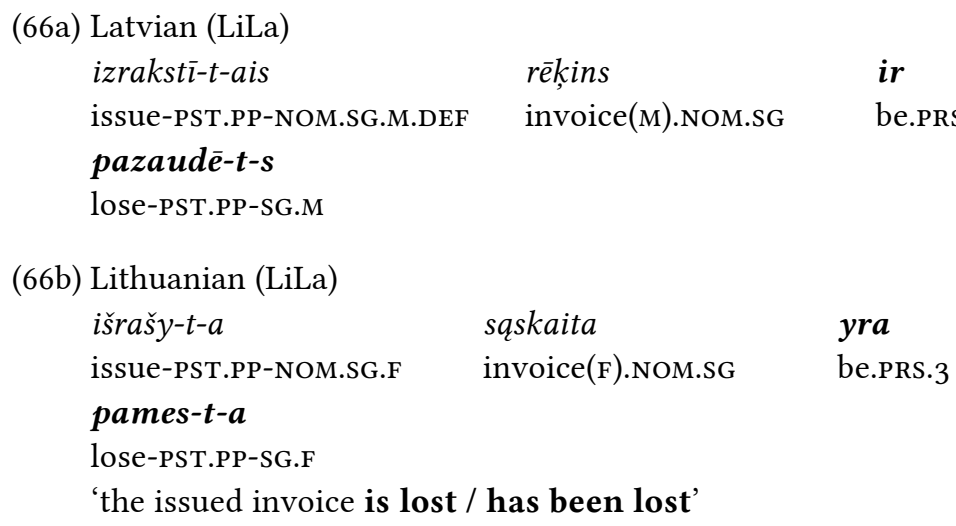

The Lithuanian example (66b) can have two meanings: a resultative meaning (present tense of the objective resultative/stative passive) or a present perfect meaning (present perfect tense of the actional passive) (cf. Geniušiene \& Nedjalkov 1988, 372). The form is ambiguous also in Latvian. However, in Latvian there is also an explicit perfect construction with the past active participle of the auxiliary tikt, as in (67). This may contrast with a resultative construction as in (68). 
(67) Latvian (LVK2018)

\begin{tabular}{|c|c|c|c|}
\hline Labklājība & vienmēer & ir & $i k-u s-i$ \\
\hline prosperity(F).NOM.SG & always & be.PRs.3 & UX-PST.PA-SG.F \\
\hline atz & par & pozitīvu & vērtību. \\
\hline dge-PST.PP-SG.F & for & positive.ACC.SG & value.Acc.sG \\
\hline
\end{tabular}

(68) Latvian (LVK2018)

Mine $\bar{e}-t-\bar{a}$

mention-PST.PP-NOM.SG.F.DEF

$a t z \bar{\imath}-t-a$

$\bar{e} k a$

ir

acknowledge-PST.PP-SG.F for

building(F).NOM.SG

be.PRS.3

nozimìgu

kultūrvēsturiski

significant.ACC.SG

'The mentioned building is acknowledged as having a heritage value', i.e. has the acknowledged status of cultural heritage.

However, the participle of tikt is often dropped and a construction 'be' + PST.PP is therefore ambiguous or vague between resultative and perfect (cf. Holvoet 2001b, 163-165). A participle that is often used in a purely resultative construction is prone to lexicalization and may become an adjective. The passive participle of atzit 'acknowledged' shown in (67) and (68) is already included in dictionaries of Latvian as a lemma of its own. ${ }^{13}$

With the 'be' auxiliary in past tense, the participle of the auxiliary tikt is very rare (only five examples of bija tikt.PST.PA + PST.PP in the corpus LVK2018), which means that in the past the difference between resultative and passive is even more blurred (69a). According to Geniušiene \& Nedjalkov $(1988,372)$, in Lithuanian the combination of a past tense auxiliary with a $t$-participle as in $(69 \mathrm{~b})$ can have three meanings: a resultative meaning (past tense of the objective resultative/stative passive), a simple past meaning of the actional passive, and a past perfect meaning of the actional passive.

${ }^{13}$ Of course, whether a participle is included in a dictionary as a separate lemma also depends on general lexicographic decisions and traditions. In Lithuanian dictionaries, participles rarely have a separate entry, even if they are used more frequently than finite forms of the verb, for example, nusagstytas 'studded'. 
(69a) Latvian (LiLa)

[Un vēlāk man sametās kauns, ka publiski biju tā izlielījusies un sasolījusi zilus brīnumus, tikai šì nožēela mani k̦ēra par vēlu-]

pirmā grāmata bija jau

first.NOM.SG.F.DEF book(F).NOM.SG be.PST.3 already

uzrakstī-t-a.

PVB.write-PST.PP-SG.F

(69b) Lithuanian (LiLa)

[Dar vèliau man pasidarè gèda, kam taip viešai išsiliejau ir neregèta

stebukla žadejau, tik kad tas apgailestavimas vélai aplanké -]

pirmoji knyga buvo jau

first.NOM.SG.F.DEF book(F).NOM.SG be.PST.3 already

parašy-t-a.

PVB.write-PST.PP-SG.F

'[Later I became ashamed that I had boasted publicly and promised miraculous things, only this feeling of regret came too late-] the first book was already written / had already been written.'

Also in the future, the distinction between a future event and a future state resulting from this event is fuzzy. In (70a, b) it is clear from the preceding context that the speaker is referring to a future state (imagined by him/her).

(70a) Latvian (LiLa)

uz kapsētas būs uzcel-t-a

on graveyard.GEN.SG be.FUT.3 PVB.build-PST.PP-SG.F

mašinu un traktoru stacija.

car.GEN.PL and tractor.GEN.PL station(F).NOM.SG

(7ob) Lithuanian (LiLa)

kapiniu vietoje bus pastat-a

graveyard.GEN.PL place.LOC.SG be.FUT.3 build-PST.PP-SG.F mašinu ir traktoriu stotis

car.GEN.PL and tractor.GEN.PL station(F).NOM.SG

'a machine and tractor station will be built on the place of the graveyard'

In Lithuanian the use of $t$-passives (including resultatives) differs significantly in different tenses: present tense $60 \%$, past tense $31 \%$, future tense 6\% (Geniušienè \& Nedjalkov 1988, 374). Interestingly, the ratio of stative and actional passives also differs with respect to different tense forms. 
Table 13. Frequency of resultative and actional meaning in Lithuanian passive forms relative to different tenses (adapted from Geniušienė \& Nedjalkov 1988, 374)

\begin{tabular}{l|l|l|l}
\hline \multirow{2}{*}{$\boldsymbol{t}$-passives } & \multicolumn{3}{|c}{ Tense } \\
\cline { 2 - 4 } & present & past & future \\
\hline resultative meaning & $75 \%$ & $64 \%$ & $15 \%$ \\
actional meaning & $25 \%$ & $36 \%$ & $85 \%$
\end{tabular}

Table 13 shows that resultative meaning dominates in present and past tense, while future $t$-passives mostly have a dynamic meaning. Therefore, examples like (7ob) are rare.

According to Geniušiene (2016, 80; 227), the stative passive is the most frequently used variety of the passive in Lithuanian. It amounts to $40-50 \%$ of all passive forms in her corpus of 5,730 passive constructions. Though in many cases the context helps us to distinguish stative passives from actional passives, there are cases of semantic and syntactic ambiguity where it is impossible or even meaningless to delimit the two constructions (Geniušiene 2016, 81). In Latvian, where we have a dedicated construction for the actional passive (with the auxiliary tikt, cf. Section 3), this construction is more frequent than the one with the auxiliary büt 'be'.

Geniušiene $(2016,91)$ mentions a property that pertains only to the stative-the passive participle can be conjoined with simple adjectives used predicatively; cf. (71).

(71) Lithuanian (cited from Geniušienè 2016, 91)

\begin{tabular}{llll} 
Sodybos & vartai & nauji, & zaliai \\
homestead.GEN.SG & gate(PL.M).NOM new.NOM.PL.M & green \\
nudažy-t-i, & tokie & iškilmingi. & \\
paint-PST.PP-PL.M & so & festive.NOM.PL.M \\
\multicolumn{2}{l}{ 'The gate of the homestead is new, painted green, so festive.' }
\end{tabular}

To sum up, the stative passive in Baltic exhibits the following features:

- Agent defocusing - the actor is unknown or (for different reasons) unimportant; in general, it is not the topic of the text passage (but in (69ab) this is not so clear, the passage is about the author's feelings). 
- Object to Subject promotion-the verbs are transitive and the Direct Object appears as the Subject of the Passive construction (nominative, agreement).

- An agent phrase is impossible (but see 5.2 and 5.3 below).

- The verbs are telic; achievements and accomplishments.

- The actors are human, the undergoers usually inanimate. The actions are intentional and the undergoers are affected-thus, the main arguments are typical agents and patients.

- In terms of information structure, the referent of the subject usually is the topic, $(66 \mathrm{a}, \mathrm{b})$, but it may also be part of the rheme, that is, new (7o a, b). In the latter case it appears after the verb and the clause typically starts with a locative expression. In (69 a, b) we have a clause where all is new.

\subsection{Quasi-resultative or stative proper}

Stative passives which are derived from stative verbs are termed quasiresultatives by Nedjalkov \& Jaxontov $(1988,14)$. They are 'statives proper' as they express a state without presupposing a previous event; cf. (72).

(72) Lithuanian (DLKT)

$\begin{array}{lllll}\text { Baluošo } & \text { ežeras } & \text { iš } & \text { visu } & \text { pusiu } \\ \text { PLN.GEN } & \text { lake.NOM.SG } & \text { from } & \text { all.GEN.PL } & \text { side.GEN.PL } \\ \text { apsup-t-as } & \text { mišku } & & \\ \text { surround-PST.PP-SG.M } & \text { wood.GEN.PL }\end{array}$

'Baluošas Lake is surrounded by woods from all sides'

While stative passives (or resultatives proper) are incompatible with an agent phrase (Geniušienè 2006, 31), example (72) contains a genitive which resembles an agentive object of the passive (mišku 'by woods'). Nedjalkov and Jaxontov $(1988,50)$ call such arguments AGENTIVE OBJECTS and distinguish between a DYNAMIC AGENTIVE OBJECT, whose referent does not participate in the resultant state, and a STATIC AGENTIVE OBJECT, whose referent does participate in the (resultant) state. The latter type is illustrated by (72). A static agentive object often cannot be omitted, as it is 'semantically obligatory', it is also typically non-human (cf. Geniušiene 2016, 76-77). According to Nedjalkov and Jaxontov (1988, 51), "[s]tatic 
agentive objects occur in about 70 per cent of textual examples of resultative and quasi-resultative constructions with the agentive object." ${ }^{\prime 4}$ As observed by the authors (ibid., 14), quasi-resultatives in languages tend to be formed from verbs of two lexical groups: i) verbs of physical contact and ii) emotive verbs. (72) is an example of the contact quasi-resultative, while (73) represents the emotive group:

(73) Lithuanian (DLKT)

[Liūtas baugiai urgztelejo, bet, manau,]

pats buvo per daug prislèg-t-as

self.NOM.SG.M be.PST.3 too much oppress-PST.PP-SG.M

nelaimès ir manęs nepuolè.

disaster.GEN.SG and 1SG.GEN NEG.attack.PST.3

'[The lion growled fearfully, but I think] it was too disheartened by the disaster so it did not attack me.'

Holvoet et al. (2019, 227-231) make the interesting observation that verbs occurring in stative passives with obligatory agents have something in common-they are holistic surface impact verbs (e.g. užversti 'cover, bury under', uždengti 'cover', apsupti 'surround', nutvieksti 'suffuse (with light)', $u z ̌ l i e t i$ 'bathe, suffuse (with light)'). In clauses with these verbs, the theme argument may be the subject. Consequently, in a passive construction with $u \check{z} v e r s t i$ 'cover', the theme-argument may occur in the agent position and acquire genitival marking (though instrumental case is also possible and indeed more frequent); cf. (74a, b).

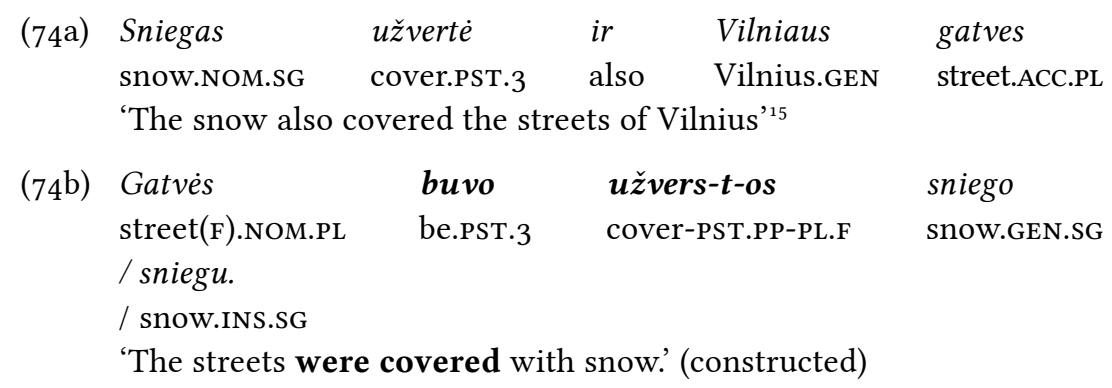

\footnotetext{
${ }^{14}$ It is not clear which language or languages Nedjalkov \& Jaxontov $(1988,51)$ are referring to.

${ }^{15}$ https://www.tv3.lt/naujiena/lietuva/372835/sniegas-uzverte-lietuva-vilniaus-meras-siuloji-nusikasti-patiems
} 
Verbs denoting emotional (and mental) states, cf. apnikti 'beset', iškankinti 'torture, torment', prislegti 'depress, oppress', apimti 'envelop', persmelkti 'pervade', iškreipti (veida) 'distort (face)', behave similarly to holistic surface impact verbs. Here the surface impact is metaphorical: the emotional state covers or fills the whole individual:

(75) Lithuanian (DLKT)

$\begin{array}{llll}\text { Džekas } \quad \text { buvo } & \text { apim-t-as } & \text { ekstazés. } \\ \text { PN.NOM } & \text { be.PST3 } & \text { envelop-PST.PP-NOM.SG.M } & \text { ecstasy.GEN } \\ \text { 'Jack was } & \text { enveloped with ecstasy.' } & \end{array}$

The same subtypes of quasi-resultatives are found in Latvian, cf. (76-78). The genitive always precedes the participle. In (76) we see a human referent in the role of agentive object. Nevertheless, the clause expresses the state of the square being encircled, not a prior action of the policemen.

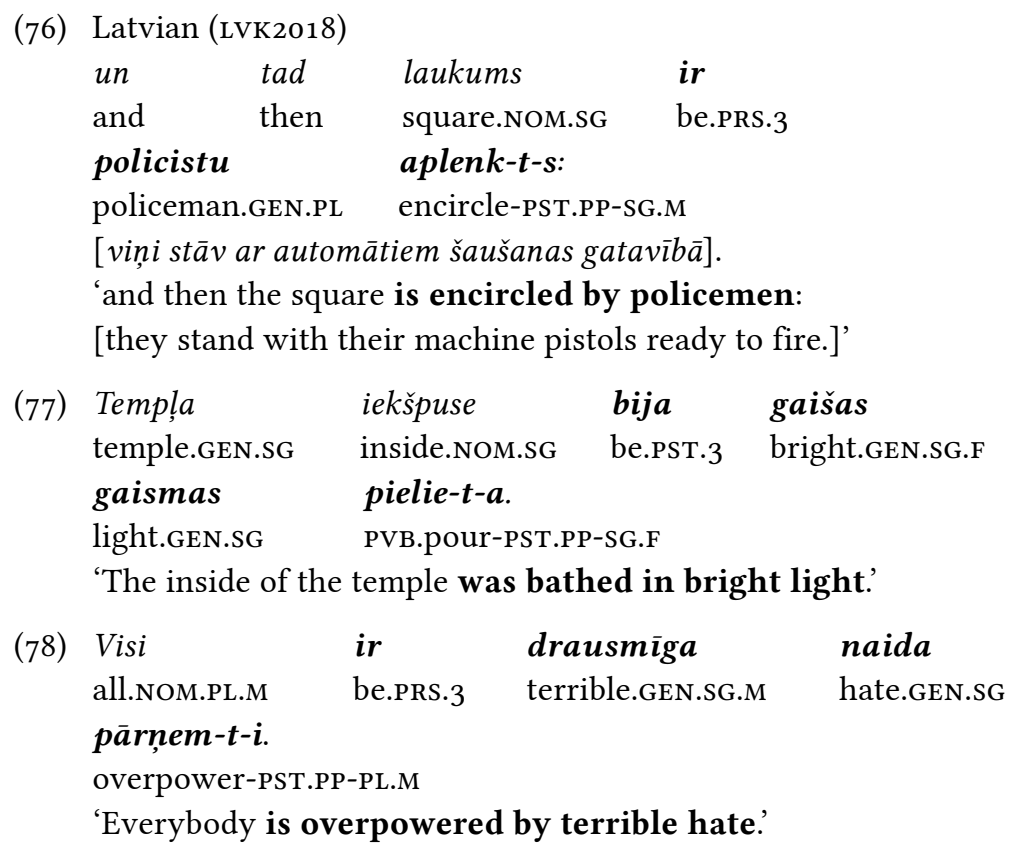

\subsection{Qualitative resultatives}

As described in Section 5.1, a resultative proper, formed from telic verbs, expresses a state as a result. The fact that this state exists may be newsworthy in itself, cf. (79). 
(79) Latvian (lvTenTen14)

[Šodien, pēc piecpadsmit Biedrības pastāvēšanas gadiem beidzot šie

vārdi var izskanēt-]

bibliotēkas èka ir uz-cel-t-a.

library.GEN.SG building.NOM.SG be.PRS.3 PVB-build-PST.PP-SG.F '[Today, after fifteen years of existence of the Society, finally these words can ring out:] the building of the library is erected.' (i.e., it now stands, is ready for use)

With an atelic verb, such a simple clause is pragmatically odd:

(79') Latvian

? Bibliotēkas ì $\quad \bar{k} a \quad$ cel-t-a.

library.GEN.SG building.NOM.SG be.PRS.3 build-PST.PP-SG.F

'The building of the library is built.'

To be informative, some qualifying element has to be added, as in (80).

(8o) Latvian (lvTenTen14)

$\bar{E} k a \quad$ cel-t-a no sarkaniem

building.NOM.SG build-PST.PP-SG.F of red.DAT.PL.M

ķieǵeḷiem.

brick.DAT.PL

'The building is built of red bricks.'

We call this type of construction QUALITATIVE RESUltative. It is used in Latvian and Lithuanian alike. As pointed out, a difference to the resultative proper is the use with atelic verbs. Telic verbs are also possible, cf. (81) and (85) below.

(81) Latvian (LVK2018; part of a review where the thesis is characterized) Promocijas darbs ir promotion.GEN.SG work.NOM.SG be.PRS.3

uz-rakstī-t-s latviešu valodā.

PVB-write-PST.PP-SG.M Latvian.GEN.PL language.LOC

'The $\mathrm{PhD}$ thesis is written in Latvian.'

The construction is often found with verbs of creation, such as 'build', 'found', 'write', 'compose', etc. The qualifying element may express the material or manner used in the creation, as in $(80,81)$ from Latvian and (82) from Lithuanian.

(82) Lithuanian (ltTenTen14)

$\begin{array}{lllll}\text { Muziejuje } & \text { yra } & d u & \text { Korano } & \text { egzemplioriai- } \\ \text { museum.LOC.SG } & \text { be.PRS.3 } & \text { two } & \text { Koran.GEN } & \text { copy(M).NOM.PL }\end{array}$




$\begin{array}{ll}\begin{array}{l}\text { vienas } \\ \text { one.NOM.SG.M }\end{array} & \text { printed.NOM.SG.M } \\ \text { rašy-t-as } & \text { ranka. } \\ \text { write-PST.PP-SG.M } & \text { hand.INS.SG } \\ \text { 'In the museum there are two copies of the Koran-one is printed, }\end{array}$
$\begin{aligned} & \text { ane other one is handwritten.' (literally: 'written by hand') } \\ & \text { the has.M }\end{aligned}$

Another kind of qualifying element is the creator. Nedjalkov \& Jaxontov $(1988,53)$ point out that resultatives of creation verbs in some languages may contain a dynamic (human) agentive object, which is rhematic and acquires a kind of 'qualitative force'. Their example of a dynamic agentive object from German is given in (83).

(83) German (Nedjalkov \& Jaxontov 1988, 50; our glossing) [Ich kann Ihnen ein Buch darüber geben,]

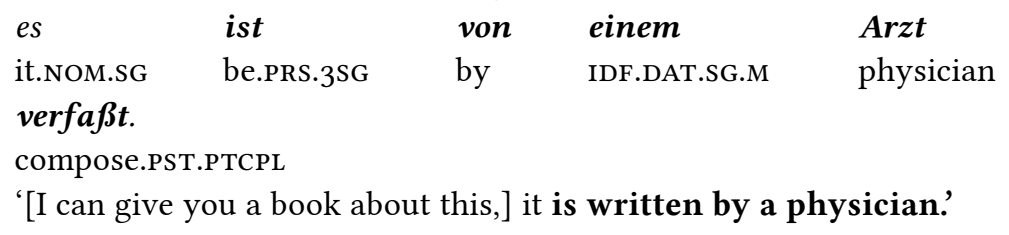

Example (83) is an objective resultative (stative passive): it is predicated that the book is in the state of having been written by a physician. By this fact it is implied that the book is of high quality and that one can trust its content. Note that without this qualifying element, the clause would be odd (?das Buch ist verfasst 'the book is composed'), or has to get a resultative reading with some stylistic value ('It is done! The book is composed!').

The use of dynamic agentive objects is also attested in Latvian. (84) is part of the reminiscence of a retired teacher. The fact that she has actively participated in building the school is important and explains her special attachment to the building. For more on the Latvian agentive construction see Holvoet et al. (2019).

(84) Latvian (LVK2018)

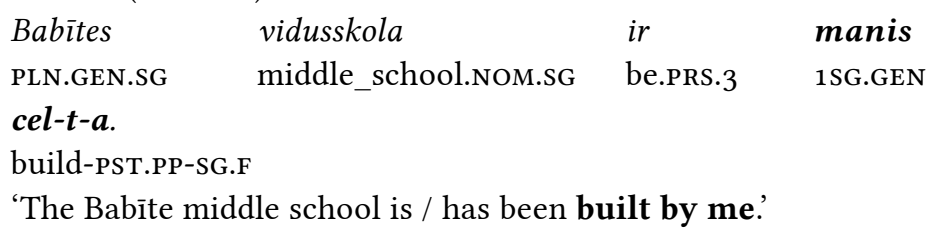

As has been mentioned above, in Lithuanian, the agentive construction evolved into an agentive passive. Nevertheless, some passives from 
creation verbs with stressed agentive objects in preverbal position can be interpreted as qualitative resultatives, as they predicate an authorship of a certain creation and a state which pertains to this creation by virtue of this authorship; cf. (85).

(85) Lithuanian

[Tarkime, spektakliui „No return“, kuris atvežamas $i$ Vilniu, panaudoti Kafkos tekstai,]

\begin{tabular}{|c|c|c|c|c|}
\hline bet & puse & antro & veiksmo & yra \\
\hline but & half.NOM.sG & second.GEN.SG.M & act.GEN.SG & be.PRS.3 \\
\hline
\end{tabular}

1SG.POSS PVB-write-PST.PP-SG.F

'[For instance, in the play No return, which is brought to Vilnius, Kafka's texts are used] but half of the second act is written by me.'

Another type of qualitative resultatives is characterized by the use of adverbials of exact time. Nedjalkov \& Jaxontov $(1988,54)$ argue that here "an adverbial of the time of action is re-interpreted as a kind of qualitative characteristic of the underlying subject of state". We may illustrate their reasoning with a Lithuanian example similar to the German example they give: In (86) the property which is predicated of the subject referent (the church) is that it is in a state of having been founded in the 12th century, which means it is old.

(86) Lithuanuan (ltTenTen14)

fi yra staty-t-a XII $a$.

3.NOM.SG.F be.PRS.3 build-PST.PP-SG.F $12 \mathrm{c}$.

[ir yra vienintelè bažnyčia Baltarusijoje, kuri niekad nebuvo perstatyta.] 'It was (literally: is) built in the 12th century [and is the only church in Belarus which was never reconstructed.]'

Qualitative resultatives with temporal adverbials are common in Lithuanian in colloquial language and show a great variety of possible lexical input. In (87) it is implied that the boiler is new, and (88) implies that the floor is relatively clean. Thus $(87-88)$ are statements about the present state of the subject, not about a past event.

(87) Lithuanian (forum post on supermama.lt)

Mūsuz katilas pirk-t-as pernai.

1PL.GEN boiler.NOM.SG buy-PST.PP-SG.M last_year

'Our boiler was bought last year.' 
(88) Lithuanian (from facebook.com)

$\begin{array}{lcl}\text { Grindys } & \text { plau-t-os } & \text { vakar. } \\ \text { floor.NOM.PL } & \text { wash-PST.PP-PL.F } & \text { yesterday } \\ \text { 'The floor was washed yesterday.' } & \end{array}$

\subsection{Summing up}

The stative passive or resultative is the branch of the Passive Family where Latvian and Lithuanian are most similar. In both languages, the distinction between resultative and perfect tenses of a dynamic passive is usually not marked formally, and it is often unimportant. At the other end, some stative passives, especially qualitative resultatives, seem to be copular constructions rather than passive constructions (if such a distinction is valid at all).

There are more variants of the stative passive which may be worth further investigation. Two of these shall be briefly mentioned. Holvoet (2001b, 171-175) describes a possessive passive in Latvian which may represent an incipient stage of a possessive perfect (well developed in Estonian, see Lindström \& Tragel 2010). Another only marginally developed construction in both Latvian and Lithuanian is the combination of an auxiliary 'stay' and a negated past passive participle (Latvian jautājums palika neatbildèts 'the question remained unanswered'). Wiemer (2004) describes the development of a regular passive from corresponding constructions in Polish, a process which however does not seem to have started in Baltic.

In Tables 14 and 15 we sum up the profiles of the three types distinguished in this section.

Table 14. Stative passive or resultative proper ('the invoice is / has been lost')

\begin{tabular}{|c|c|}
\hline Feature & Value \\
\hline Participle & PST.PP ( $t$-participle) \\
\hline Auxiliary, tense & $\begin{array}{l}\text { 'be' auxiliary in various tenses; in present tense } \\
\text { often omitted }\end{array}$ \\
\hline Actor & usually human; unknown or unimportant \\
\hline Agent phrase & not possible \\
\hline Subject & nominative subject is usually the topic \\
\hline
\end{tabular}




$\begin{array}{ll}\text { Feature } & \text { Value } \\ \text { Meaning } & \text { state resulting from prior event } \\ \text { Verbs } & \text { transitive; agentive; telic; prefixed } \\ \text { Word order } & \text { either } \mathrm{s}-\mathrm{v} \text { or Adverbial }-\mathrm{v}-\mathrm{s} \\ \text { Registers } & \text { all }\end{array}$

Table 15. Quasi-resultatives ('the streets are covered by snow') and qualitative resultatives ('the text is written by hand / by me / in the 16th century')

\begin{tabular}{|c|c|c|}
\hline Feature & Quasi-resultative & Qualitative resultative \\
\hline Participle & PST.PP ( $t$-participle) & PST.PP ( $t$-participle) \\
\hline Auxiliary & 'be', or no auxiliary & 'be', or no auxiliary \\
\hline Actor & $\begin{array}{l}\text { mainly non-human; par- } \\
\text { ticipates in the state }\end{array}$ & $\begin{array}{l}\text { human; does not partici- } \\
\text { pate in the state }\end{array}$ \\
\hline Agent phrase & $\begin{array}{l}\text { stative agentive object } \\
\text { expressed as genitive; } \\
\text { semantically obligatory }\end{array}$ & $\begin{array}{l}\text { dynamic agentive object } \\
\text { expressed as genitive; in } \\
\text { some cases semantically } \\
\text { obligatory }\end{array}$ \\
\hline Meaning & $\begin{array}{l}\text { state of a patient without } \\
\text { implication of a previous } \\
\text { action }\end{array}$ & $\begin{array}{l}\text { state of a patient imply- } \\
\text { ing a previous action; the } \\
\text { state is further qualified } \\
\text { by specifying the actor, } \\
\text { the manner or time of the } \\
\text { action }\end{array}$ \\
\hline Verbs (transitivity) & transitive & transitive \\
\hline Verbs (semantic) & $\begin{array}{l}\text { stative; holistic surface } \\
\text { impact; physical contact } \\
\text { ('covered'); emotions } \\
\text { ('overwhelmed') }\end{array}$ & $\begin{array}{l}\text { agentive; +/- telic; typi- } \\
\text { cal for verbs of creation } \\
\text { ('build', 'compose' etc.) }\end{array}$ \\
\hline Word order & $\begin{array}{l}\mathrm{s}-\text { agentive object }-\mathrm{v} \text {, } \\
\text { Lithuanian also } \mathrm{s}-\mathrm{v}- \\
\text { agentive object }\end{array}$ & $\begin{array}{l}\mathrm{s}-\mathrm{v}-\text { qualifier; } \\
\mathrm{s}-\text { agentive object }-\mathrm{v}\end{array}$ \\
\hline Registers & all & all \\
\hline
\end{tabular}




\section{Subjectless and subject-weak passives}

In this section we will examine constructions which are typical for passives from intransitive verbs and thus necessarily subjectless. However, the same constructions are found also with transitive verbs when the subject is 'weak'. By this we refer to situations where the subject of a passive is indefinite, often non-individuated, and follows the verb. In the linguistic literature, a fundamental difference is often made between passives from transitive and intransitive verbs (for example, Frajzyngier 1982), or between personal (subjectful) and impersonal (subjectless) passives. However, we found that the distinction between passives with definite and/or topical subjects on the one hand, and those with either an indefinite subject or without subject on the other is probably more important for characterizing passive constructions in Baltic.

Subjectless and subject-weak passives do not focus on a patient or theme participant. They present the pure action or state expressed by the verb. In this they are sometimes close to infinitives and nominalizations, and an English translation equivalent may contain a gerund or a noun (see examples in various parts of this section).

\subsection{From generic to definite human actor}

The demoted actor of subjectless and subject-weak passives is almost exclusively human. Certain constructions allow other animate actors such as pet animals.

Frajzyngier (1982) postulates that a passive form of intransitive verbs implies an indefinite (generic) human agent. This is not the case in the Baltic languages, where the actor often is a definite, known person. We distinguish between three types of actors with respect to referentiality (more fine-grained distinctions are of course possible):

i. generic, referring to humans in general or at a given time or place, such as Latvians in the 19th century, inhabitants of a town, potential participants of an event;

ii. indefinite, referring to certain individuals or a certain group of individuals, like the government, or just 'somebody'; the actor may or may not be known to the speaker;

iii. definite, referring to an individual or a group whose identity is known to both speaker and addressee and that is mentioned in the context. 
To get an impression of the relative frequency of these types, we used the data of the study by Lindström, Nau, Sprauniene \& Laugalienè (2020, this volume), where samples of selected intransitive verbs were drawn from the corpora lvTenTen 14 and ltTenTen 14 .

Table 16. Reference types of the covert actor in passives from selected intransitive verbs

\begin{tabular}{l|l|l|l}
\hline & $\begin{array}{l}\text { Latvian } \\
(700 \text { tokens })\end{array}$ & $\begin{array}{l}\text { Lithuanian, } \\
\boldsymbol{t} \text {-participle } \\
(500 \text { tokens) }\end{array}$ & $\begin{array}{l}\text { Lithuanian, } \\
\boldsymbol{m} \text {-participle } \\
(200 \text { tokens })\end{array}$ \\
\hline generic & $28 \%$ & $39 \%$ & $85.5 \%$ \\
indefinite & $21 \%$ & $19 \%$ & $7 \%$ \\
definite & $51 \%$ & $42 \%$ & $7 \cdot 5 \%$
\end{tabular}

The verbs chosen for these samples were the following:

- Latvian: būt 'be', braukt 'ride, drive, go by transport', dziedāt 'sing', dzìvot 'live', iet 'go', sēdēt 'sit', strādāt 'work'

- Lithuanian: dainuoti 'sing', eiti 'go', gyventi 'live', miegoti 'sleep', stoveti 'stand', važiuoti 'ride, drive, go by transport' for the $t$ participle; gyventi 'live' and važiuoti 'ride' also for the $m$-participle

The different reference types are not evenly distributed, and there are certain preferences with respect to other parameters such as the verb lexeme, the auxiliary (in Latvian), the clause type (independent or subordinate).

\subsubsection{Generic human actors}

Generic human actors are most typical for actional passives. Lithuanian subjectless $m$-passives specialize for reference to generic human actors (cf. Geniušienè 2006, 40). They are used in gnomic statements, as well as in generic-habitual sentences where reference is made to hypothetical actors; cf. (89):

(89) Lithuanian (ltTenTen2014)

$\begin{array}{lll}\begin{array}{l}\text { Klasikinio } \\ \text { classic.GEN.SG }\end{array} & \text { duatlono } & \text { varžybose } \\ & \text { duathlon.GEN.SG } & \text { competition[PL].LOC }\end{array}$




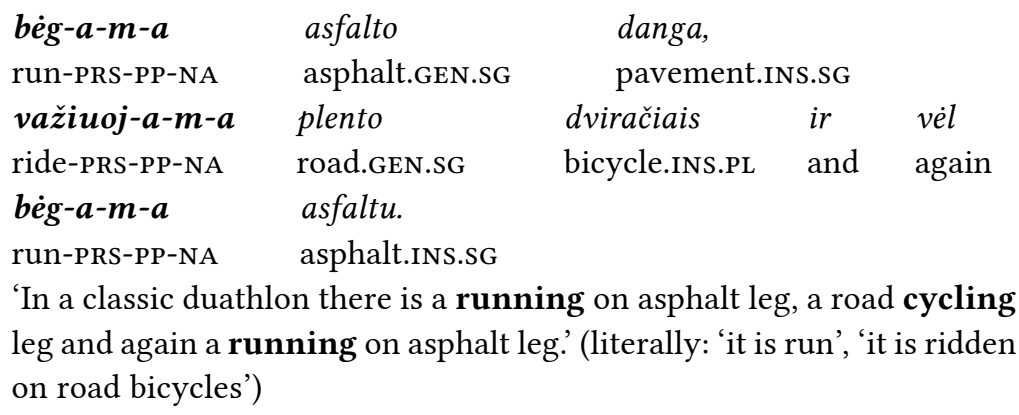

When the covert actor of a subjectless $m$-passive is generic, it is not possible to add an agent phrase such as 'by people'. Though constructed examples of agented $m$-passives are sometimes given in the literature, authentic examples of this kind are not attested. With $t$-passives this restriction is not so strict: though most examples with generic actors do not contain agent phrases (those that are found belong to the category of evidentials, see Section 7), we found a non-evidential $t$-passive with an overt generic actor 'people', see (90).

(90) Lithuanian (ltTenTen14)

[Tai po truputi issisavinom taiga,]

$\begin{array}{llll}\text { kurioje } & \text { prieš } & \text { mus } & \text { nebuvo } \\ \text { which.LOC.SG } & \text { before } \quad \text { 1PL.ACC } & \text { NEG.be.PST.3 } \\ \text { žmoniu } & \text { vaikščio-t- } \boldsymbol{a} \text {. } & \\ \text { people.GEN.PL } & \text { walk-PST.PP-NA } & \end{array}$

people.GEN.PL walk-PST.PP-NA

'So little by little we mastered the taiga where no people had walked before us.'

In Latvian, a subjectless or subject-weak passive with the auxiliary tikt 'get, become' often has a generic human actor. These constructions are most similar to impersonal passives in German or Dutch, which are well known from the literature. A typical context for impersonal passives with generic reference is reports about traditions, as in (91). An alternative to the passive is a subjectless third person active form (a Zero Subject construction). In (91), the choice of the active form for 'decorate', surrounded by passive predicates, may be motivated by the fact that the undergoer in this clause is definite and thus would become a preverbal ('strong') subject in the passive. 
(91) Latvian (lvTenTen14)

[Maija koks, parasti bērzs, ir auglības nesējs.]

meža

tika

atnes- $t-i$

from

wood.GEN.SG

AUX.PST.3

Maija

koki

un

PVB.carry-PST.PP-PL.M

May.GEN

tree.NOM.PL and

novieto-t $\boldsymbol{t} \boldsymbol{i}$

sētā,

mājas

PVB.place-PST.PP-PL.M

courtyard.LOC.SG

house.GEN.SG

priekšā.

Kokus

rotā

ar krāšñām

front.LOC.sG

tree.ACC.PL

decorate.PRs.3 with

ornate.DAT.PL

lentēm.

Ap

Maiju koku

tika

ribbon.DAT.PL

around

May.gen tree.GEN.PL AUX.PST.3 dance-PST.PP-NA

\section{dziedā-t-s un smie-t-s.}

sing-PST.PP-NA and laugh-PST.PP-NA

'The maypole, usually a birch, brings fertility. Trees for maypoles were brought from the wood and placed in the courtyard, in front of the house. The trees are decorated (literally: (they) decorate the trees) with ornate ribbons. There was dancing, singing, and laughing around the maypole.'

Generic actors are less common with verbs expressing a state. They are mostly found in subordinate clauses in sentences that express some kind of rule.

(92) Latvian (lvTenTen14)

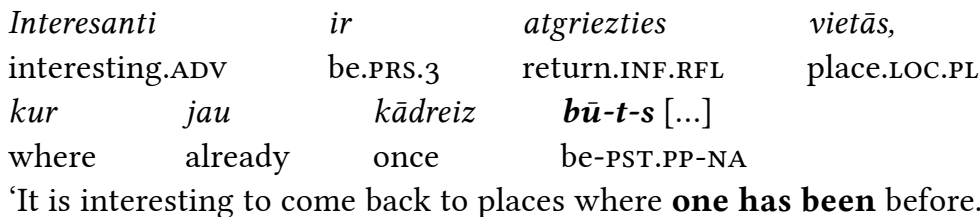

\subsubsection{Indefinite actors}

Indefinite specific agents form the smallest group with most verbs that we examined. In our Latvian sample, they were only frequent with the verb strādāt 'work', where 57 out of 100 investigated examples of a subjectless passive had an indefinite actor. With other verbs, the percentage is much lower: 5 (būt 'be', braukt 'go by transport'), 6 (sēèet 'sit'), 11 (dzìvot 'live'), 12 (iet 'go on foot') and 35 (dziedāt 'sing'). Indefinite actors are found with all three auxiliary options: tikt (example 94), būt, or zero (ex. 93). The construction can usually be translated into German by the 
impersonal passive with werden. Clauses with a passive of strādāt 'work' often refer to work done by the government or members of an organization, as in example (94).

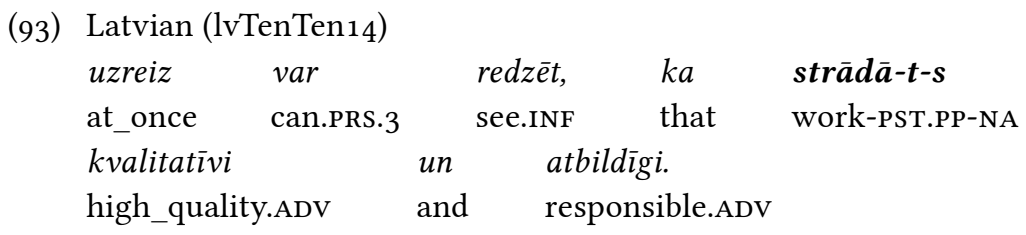

'You can see at once that work was/has been carried out in high quality and with responsibility.' (German: 'Man sieht sofort, dass hochwertig und verantwortungsvoll gearbeitet wurde/worden ist.')

(94) Latvian (lvTenTen14)

[Kā norādījis Finanšu ministrijas valsts sekretārs Mārtiņš Bičevskis,]

tiek strāa $\overline{\boldsymbol{a}}$-t $\mathbf{t}$ s pie garantijas

AUX.PRS.3 work-PST.PP-NA at guarantee.GEN.SG

fonda izveides.

fund.GEN.SG creation.GEN.SG

'According to the State Secretary of the Ministry of Finance Mārtiņš Bičevskis, work is underway to establish a guarantee fund.' (Translation by Google Translate, which gives the following German version with an impersonal passive: Nach Angaben des Staatssekretärs des Finanzministeriums, Mārtiņš Bičevskis, wird derzeit an der Einrichtung eines Garantiefonds gearbeitet. ${ }^{16}$ )

Constructions where the underlying actor is indefinite are functionally most similar to subjectful passives. They probably do not constitute a special type, as the only difference to the typical passive (see Section 3 above for the Latvian passive with tikt) is the lack of a subject or the fact that the subject is weak. Also with verbs that have other arguments than a direct object (for example, dative complements, such as Latvian palidzzēt 'help', kaitet 'harm'), the hidden actor is most often indefinite.

In the Lithuanian material, subjectless passives with indefinite actors are also the least numerous. As mentioned above, they constitute $19 \%$ of

${ }^{16}$ It is interesting that Google Translate uses impersonal passives in both Latvian and German, though presumably the translation is done via English. This attests to the high frequency of such constructions. 
the $t$-passives and $7 \%$ of the $m$-passives. Passives with indefinite actors usually refer to actions carried out by participants of a certain event as in (95) or workers of a company or institution as in (96):

(95) Lithuanian (ltTenTen14)

Antroji

renginio

dalis

buvo

second.NOM.SG.F.DEF

event.GEN.SG

part(F).NOM.SG be.PST.3

praktine -

šiaurietiškai

ei-t-a

practical.NOM.SG.F

Nordic.ADV

go-PST.PP-NA

pažintiniu

„Žaliuoju taku”

Spindžiaus

educational.INs.SG

green_trail(M).INS.SG

PN.GEN

miške.

forest.LOC.SG

'The second part of the event was practical-it consisted of Nordic walking along the educational "Green Trail" in the Spindžius forest.'

(96) Lithuanian (ltTenTen14)

\begin{tabular}{lllll} 
Viena & mašina & \multicolumn{2}{c}{ naudojasi } & \multicolumn{2}{c}{ šš } \\
one.INS.SG.F & car(F).INS.SG & use.RFL.PRS.3 six.NOM \\
ar & net & daugiau & pareigūnu. & Todèl \\
or & even & more & officer.GEN.PL & therefore
\end{tabular}

automobiliais važiuoja-m-a nuolat.

car.INS.PL drive-PRS-PP-NA all_the_time

'One car is being used by six or even more officers. That's why the cars are being driven all the time.'

Passives with evidential (inferential) meaning also have deleted indefinite actors:

(97) Lithuanian (ltTenTen14)

[Tik virš veja apžèlusios kalvelès išlindę keli kaminai išduoda,]

jog čia gyven-a-m-a.

that here live-PRS-PP-NA

'[Only a few chimneys protruding above the grassy hill betray] that someone lives here.'

Lithuanian agentless passives are in some cases interchangeable with indefinite personal constructions (for details see Geniušienė 2016, 247-268).

\subsubsection{Covert definite actors}

Definite actors are especially interesting in that they defy the general assumption often found in the literature that passives are used when the 
actor is unknown, generic or indefinite. The examples that fall into this category cannot be translated by a German impersonal passive; their most natural equivalent in German as well as in English is an active construction with the actor as subject.

In both Latvian and Lithuanian, in passives of intransitive verbs with a $t$-participle and the auxiliary 'be', a definite actor is relatively frequent (see Table 16 above).

In Lithuanian, definite actors are common in subjectless passives with the $t$-participle, but rare with the $m$-participle. In a sample of 100 agentless $t$-passives, the amount of instances of definite actors ranges from 30 (with the verb gyventi 'live') to 65 (with the verb važiuoti 'ride, drive, go by transport'). In the case of $m$-passives, the amount of definite actors is also bigger with važiuoti 'ride, drive, go by transport' than with gyventi 'live' (10 vs. 5 out of 100 respectively).

In Latvian, definite actors appear with both auxiliaries, but are more frequent in constructions with the auxiliary $b \bar{u} t$ 'be' or without an auxiliary. They are relatively less frequent with pure activity verbs ('sing', 'work') and more frequent with verbs of displacement and localization ('go (to)', 'ride (to)', 'sit', 'be (at)', live (at)').

The identity of the actor is mainly to be inferred from the context. In general, it is the person that is currently being talked about. The passive construction alternates with a personal active form or a past active participle that agrees with the actor in number and gender. Reference assignment seems to be similar as in the case of modal verbs that are morphologically third person (for example, Lithuanian reikèti 'need', norètis 'want (for oneself)', Latvian vajadzēt 'need', gribēties 'want') or the Latvian debitive formed with the prefix $j \bar{a}-$. With these verbs and forms, the actor may be added as a dative argument, but is often omitted when the referent is given in the context. As a kind of default, reference is related to the speaker, as in example (98), where both a debitive and a passive participle refer to the speaker as actor.

(98) Latvian (lvTenTen14)

$\begin{array}{lllcc}\text { "Rokas } & \text { gan } & \text { bij } & \text { jā-mazgā, visu } \\ \text { hand.NOM.PL } & \text { PTC } & \text { be.PST.3 } & \text { DEB-wash } & \text { all.ACC.SG } \\ \text { dienu } & \text { ar } & \text { lopiem } & \text { strādā-t-s," } \\ \text { day.ACC.SG } & \text { with } & \text { cattle.DAT.PL } & \text { work-PST.PP-NA } \\ \text { [Bisars sacijja, rokās skatīdamies. "Raug, cik melnas!"] }\end{array}$


'"I should have washed my hands, (for) I have been working all day with the cattle," [Bisars said, looking at his hands. "Look, how black (they are)!"]'17

In Latvian, a subjectless passive with a definite actor most often refers to the speaker, while in Lithuanian, reference to a third person is slightly more frequent then to the first person (see Lindström et al. 2020, this volume, for details). In both languages, a passive participle only rarely refers to the addressee.

In Lithuanian, the demoted actor may be added to the passive predicate as an agent phrase, as in (99); see also example (102) in Section 6.2.

(99) Lithuanian (ltTenTen14)

$\begin{array}{lrll}\text { Seniai } & \text { jau } & \text { mano } & \text { gyven-t-a } \\ \text { long_time } & \text { PTC } & \text { 1SG.poss } & \text { live-PST.PP-NA } \\ \text { kaip } & \check{z} \text { mogaus. } & & \\ \text { as } & \text { man.GEN.SG } & & \end{array}$

'It's been long time since I lived as a human.' (=decently)

This shows that the motivation for the passive is not to avoid mention of the first person, for example for reasons of politeness.

Latvian does not use agent phrases, but the actor may be explicitly mentioned in the context, as in (100). From a discourse point of view, the overt expression of the actor by a pronoun or a personal ending in the following clauses is simply not necessary, as the actor is the topic: in a given text passage, all predicates relate to the person or persons talked about.

(100) Latvian (lvTenTen14)

[Šajā dienā daži pārskata gada notikumus, daži raksta apṇemšanās sarakstus nākamajam gadam.]

\begin{tabular}{|c|c|c|c|c|c|c|c|}
\hline$J a$ & $\begin{array}{l}\text { runāj } \\
\text { talk.PI }\end{array}$ & $\begin{array}{l}\boldsymbol{u} \\
\text { S.1SG }\end{array}$ & $\begin{array}{l}\text { par } \\
\text { about }\end{array}$ & $\begin{array}{l}\text { sevi } \\
\text { self.ACC }\end{array}$ & $\begin{array}{l}\text { tad } \\
\text { then }\end{array}$ & \multicolumn{2}{|c|}{ šajā } \\
\hline & & ir & \multicolumn{3}{|c|}{ piedzīvo-t-i } & loti & $d a u d z$ \\
\hline & C.SG & be.PRS.3 & \multicolumn{3}{|c|}{ experience-PST.PP-PL.M } & very & much \\
\hline & & ir & & $z$ & & {$[\ldots]$} & \\
\hline
\end{tabular}

'[On this day some people review the events of the year, some write lists of resolutions for the coming year.] When it comes to myself

${ }^{17}$ This example comes from one of the few older texts contained in the corpus lvTenTen 14 , the novel Mèrnieku laiki by Reinis and Matīss Kaudzìte (1879). 
[literally: 'when I talk about myself'], this year there were very many events (that I) experienced, there was a lot of work(ing) [...]' ('I experienced very many events, I worked/have been working a lot')

With reference to the first person these passives are typically found in blogs or other forms of personal reports, also in interviews. With reference to a third person, they are typical for press texts that report about a person or group of persons.

Subjectless and subject-weak passives with a definite actor form a branch of the passive family. They can be further differentiated according to temporal and aspectual meanings, with which we will deal in the two following sections. Most examples in these sections will have a definite actor. However, the constructions are also found with generic or indefinite actors, which means that their correlation with definite actors is only an (often strong) tendency but not a rule.

\subsection{The cumulative construction}

In both Baltic languages we have identified a type of usage of past passive participles ( $t$-participles) that we have termed CUMULATIVE CONSTRUCTION. We start the description with Lithuanian and then point out what is common and what is different in Latvian.

\subsubsection{Lithuanian}

In Lithuanian, the construction is typically formed by a neuter $t$-participle without an auxiliary. A typical example of this construction is given in (101).

(101) Lithuanian (ltTenTen14)

[Kur norètumète groti, kad klausytoju būtu daugiau?

м: Labiausiai aišku užsienyje. Nes čia viskas yra tas pats.]

Visa gyvenima čia gyven-t-a,

whole.Acc.sg life.Acc.sG here live-PST.PP-NA

gro-ta, ei-t-a $\quad i \quad$ koncertus.

play-PST.PP-NA attend-PST.PP-NA to concert.ACC.PL

'[Where would you like to play in order to have more listeners? M: Most of all of course we would like to play abroad. Because here everything is the same.] Here we have lived, played and gone to concerts all our lives.' 
The construction usually refers to actions in the past of the life of a person or a group of persons which are either recurrent or which took a long time. For this reason we have called this construction cumulative: it denotes that some actions, so to speak, 'accumulated' in the past because they occurred many times or lasted for a long time. Iterativity of the past event(s) is often additionally expressed lexically using quantifying expressions such as tiek 'so much/so many times', kiek 'how much/how many times', kiek daug 'so many times', tiek kartu 'so many times', ne karta 'several times', kelios dešimtys 'several dozens', daug 'much/many'. The predicate does not refer to a specific event, but rather to a type of event, instances of which occurred within a certain period. The construction is thus type-focusing in the sense of Dahl \& Hedin (200o). While an event type itself is not located in time and space, its instantiations are usually related to regions in time and space. In the Lithuanian construction, reference to the place where the past event(s) happened is often made by using place adverbs such as čia 'here' (as in 101) and others. Compared with its active counterpart, (101) has a distancing effect: the speaker, so to speak, looks upon himself from the side.

Listing of verbs as in (101) is common for this construction. The listed verbs do not refer to a sequence of successive events; they are enumerated in a more or less accidental order, describing what used to happen in the past. Because of its orientation towards the past, the Lithuanian construction may more precisely be named 'cumulative-retrospective'.

As is evident from the English translation of (101), it is the speaker who is referring to himself and the members of his music band by using a passive form. The underlying actor is thus first person plural. This is an important feature of the cumulative construction: The demoted actor is in many cases definite (identifiable for the addressee). Normally, the identity of the underlying actor is recoverable from the context, as in (101), but in some cases the actor is overtly expressed in the construction as a genitival NP or a possessive pronoun, cf. (102):

(102) Lithuanian (DLKT)

$\begin{array}{lllc}\text { Kiek } & \text { anuomet } & \text { mano } & \text { vaikščio-t-a } \\ \text { how_much } & \text { at_that_time } & \text { 1SG.POSS } & \text { walk-PST.PP-NA } \\ \text { gatvemis, } & \text { kiek } & \text { pamaty-t-a, } & \text { kiek } \\ \text { street.INS.PL } & \text { how_much } & \text { see-PST.PP-NA } & \text { how_much } \\ \text { nekantriai } & \text { ieško-t-a! } & & \end{array}$


impatiently search_for-PST.PP-NA

'How much I walked along the streets at that time, how much I saw, how much I impatiently searched for things!'

The demoted actor of a cumulative construction may as well be third person singular or plural-either overt (103) or covert (104):

(103) Lithuanian (LithuanianWaC v2)

[Mažasis Liudukas augo trečias vaikas šeimoje, triju seseru būryje.]

Čia jo verk-t-a, juok-t-a-si,

here 3.GEN.SG.M cry-PST.PP-NA laugh-PST.PP-NA-RFL

dainuo-t-a

sing-PST.PP-NA

'[Little Liudukas grew up as a third child in the family, surrounded by three sisters.] Here he cried, laughed, sang'

(104) Lithuanian (DLKT)

[Dieve, čia ta pati Utena, apie kuria net nakti prabudęs apkasuose galvojo.] Kaip brangios tos smeletos,

how dear.NOM.PL.F DEM.NOM.PL.F sandy.NOM.PL.F

tos purvinos gatveles, kuriomis

DEM.NOM.PL.F dirty.NOM.PL.F street(F).NOM.PL which.INS.PL.F

čia vaikščio-t-a ir važiné-t-a.

here walk-PST.PP-NA and drive-PST.PP-NA

'[Oh God, this is the same Utena which he was thinking of even when he would wake up at night in the trenches.] How dear to him are those sandy dirty streets here along which (he) used to walk and drive.'

With an overt actor, the cumulative construction resembles the evidential construction described in Section 7 , but there are also differences: The cumulative construction does not express evidential meaning and the Genitive of Agent is not obligatory. The most important difference is that the cumulative construction is restricted to verbs with human subjects, while the Evidential allows for all kinds of verbs, including those with nonhuman subjects. This corroborates the cross-linguistic rule that impersonal passives and impersonals must have human actors (cf. Frajzyngier 1982).

The lexical input of the cumulative construction is mainly intransitive verbs. As far as lexical aspect is concerned, atelic verbs denoting activities (vaikščioti 'walk', dalyvauti 'participate', dirbti 'work', dainuoti 'sing', koncertuoti 'give a concert', lipti 'climb', studijuoti 'study', verkti 'cry', etc.) and states (žiūrèti 'look, watch', kentèti 'suffer', ilgètis 'long for', gyventi 'live', svajoti 'dream', liūdèti 'grieve' etc.) are dominant. Transitive verbs 
denoting activities may also occasionally occur; some are atelic (e.g. rašyti raštus, prašymus 'write papers, requests'), others are telic (e.g. isimyleti 'fall in love', pastebeti 'notice', sukurti vaidmeni 'build a character', režisuoti spektakli 'direct a play'). However, canonical subjects (corresponding to the direct object of the active) are rarely found in the cumulative construction. In (105) the participles of the transitive verbs sukurti (vaidmeni) 'build (a character)' and režisuoti (spektakli) 'direct (a play)' are used with the non-agreeing ending, as their subjects don't trigger agreement (see Section 2.3). Agreement is found between the last predicate dirbti 'work (verb)', and the cognate object darbas 'work (noun)'. All three subjects are indefinite and occur in postverbal (rhematic) position.

(105) Lithunaian (DLKT)

[Už jos pečiu—trisdešimt septyneri darbo metai tik Muzikiniame teatre.]

Čia sukur-t-a kelios dešimtys

here build-PST.PP-NA several.NOM.PL.F tenth(F).NOM.PL

vaidmenų, režisuo-t-a 23

character.GEN.PL direct-PST.PP-NA 23 various.GEN.SG

žanro spektakliai, daug koncertuo- $t$ - $a$,

genre.GEN.SG play(M).NOM.PL much give_concerts-PST.PP-NA

dainuo-t-a per radija, dirb-t-as

sing-PST.PP-NA on radio-ACC.SG work-PST.PP-NOM.SG.M

ir pedagoginis darbas.

also pedagogical.NOM.SG.M work(M).NOM.sG

'[Behind her shoulders there are 37 years of work in the Musical Theatre.] Here she built several dozens of characters (literally: here several tens of characters were built), directed 23 plays of various genres, gave a lot of concerts, sang on the radio and also worked as a teacher.' literally: '23 plays of various genres were directed'

Often, however, the direct object of a transitive verb used in the cumulative construction is not only indefinite, but also quantified and therefore appears in the genitive, hence does not trigger agreement, as in (106) raštų 'letters', prašymų 'requests'.

(106) Lithuanian (DLKT)

[Galu gale $1994 \mathrm{~m}$. lapkričio $11 \mathrm{~d}$. Vilniaus miesto valdyba patvir-

tino tu pačiu metu sausio $3 d$. tarybos sprendima perduoti gimnazija

jezzuitams. Dabar, kai žiūri iš šalies, viskas atrodo labai paprasta.]

$\begin{array}{llll}\text { O } & \text { kiek } & \boldsymbol{r a s ̌ y - t}-\boldsymbol{a} & \boldsymbol{r a s ̌ t}-\boldsymbol{u}, \\ \text { but } & \text { how_many } & \text { write-PST.PP-NA } & \text { paper-GEN.PL }\end{array}$




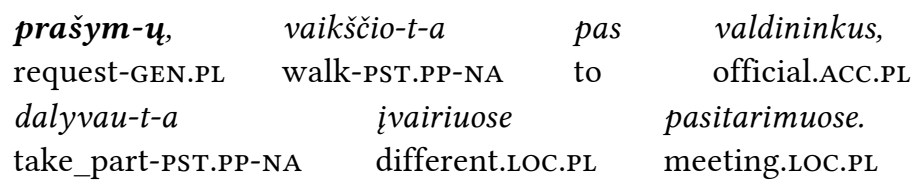

'[At last on the 11th of November 1994 the Council of Vilnius approved of the Council's decision of January 3 to give the gymnasium to the Jesuits. Now when you are looking at it from the side everything seems simple.] But how many papers and requests were written, how many officials were contacted, how many different meetings were attended.'

It is also possible (though very rare) that an object is not promoted to subject and retains accusative marking. This is shown in (107) with the last predicate, mylèta tévu žemę 'loved (one's) homeland'. The actor of all three predicates in this example is generic.

(107) Lithuanian (ltTenTen2014)

[Mirtis yra kažkas savaime suprantamo, bet trèmimai i Sibira be jokios kaltès, vien už tai,]

\begin{tabular}{|c|c|c|}
\hline $\begin{array}{l}\boldsymbol{b u v} \text {-o } \\
\text { be-PST.3 }\end{array}$ & $\begin{array}{l}\text { sąžiningai } \\
\text { honestly }\end{array}$ & $\begin{array}{l}\text { dirb-t-a } \\
\text { work-PST.PP-NA }\end{array}$ \\
\hline$y v e n-t-a$, & $t i k \dot{e}-t-a$ & Dieva \\
\hline ST.PP- & believe-PST.PP-NA & God.ACC.SG \\
\hline$l \dot{e}-t-a$ & $t \dot{e} v-u_{t}$ & žem-ę, \\
\hline
\end{tabular}

love-PST.PP-NA father-GEN.PL land-ACC.SG

[netilpo žmoniu galvose.]

'[Death is natural, but deportation to Siberia without any guilt, only because] one (had) worked and lived honestly, believed in God and loved one's homeland, [was beyond people's understanding.]'

As was mentioned above, in the cumulative construction the non-agreeing form of the $t$-participle is normally used without an auxiliary. In those rare cases where an auxiliary is used, it occurs in the past tense, cf. (107).

Example (107) differs slightly from the examples presented before as it does not contain explicit quantifiers (as in 102, 105, 106) and also does not imply repeated activities of a type (as 101, 103, 104). However, the situations described in (107) are understood as long-lasting. Furthermore, it contains a temporally not ordered list of activities or states, which is a typical feature of the cumulative construction.

The borders of the construction may be fuzzy. Example (108) deviates from the typical instances in that the evoked situations occurred only 
once and are not described as long-lasting. On the other hand, it contains two events which are listed as significant situations in the memory of the speaker, thus it still may be called 'cumulative-retrospective'.

(108) Lithuanian (ltTenTen2014)

\begin{tabular}{llll} 
Kartu & budie-t-a & \multicolumn{1}{c}{ prie } & Seimo \\
together & stand_in_guard-PST.PP-NA near & Parliament.GEN.SG \\
tragiškaja & \multicolumn{1}{c}{$1991-$-uju } & sausio & 13-osios \\
tragic.ACC.SG.F.DEF & 1991 & January.GEN & 13th
\end{tabular}

nakti, stovie-t-a Baltijos kelyje.

night(F).ACC.SG stand-Pst.PP-NA Baltic.GEN.SG way.LOC.SG 'Together we stood in guard near the Parliament on the tragic night of the 13th of January 1991, we also stood in the Baltic Way.'

\subsubsection{Latvian}

In Latvian, there seems to be more variation within the cumulative construction. It is possible to distinguish several subtypes, or alternatively see cumulative constructions as subtypes of types otherwise defined.

Some examples, such as (109), show the same characteristic features as identified in Lithuanian: the participle is used without auxiliary, the verbs are mainly intransitive, or transitive verbs used without a nominative subject, therefore there is no agreement, the sentence contains a temporal quantifier and reference to a place.

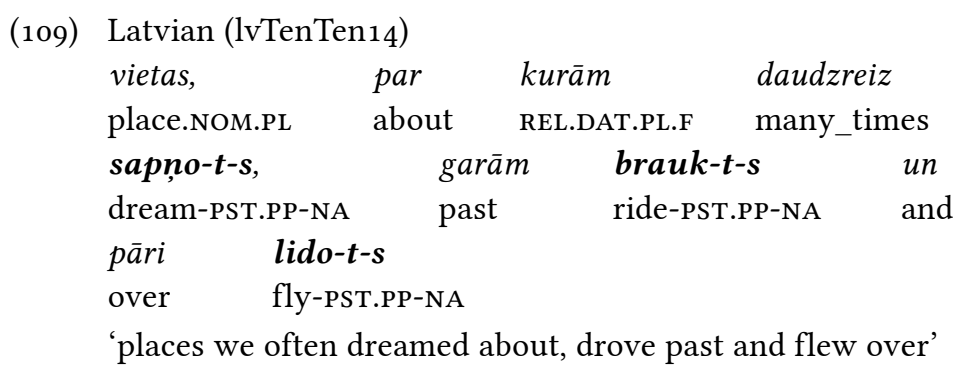

However, it seems that in Latvian more often than in Lithuanian the construction - or another subtype-is also used with transitive verbs and nominative subjects-most often, but not always indefinite. Another and probably more important difference is that the auxiliary 'be' is frequently found in a Latvian cumulative construction, and it is in present tense. Both these features can be seen in (110): with the first participle in a sequence of coordinated clauses, the auxiliary is used, and the first two 
predicates contain a nominative subject with which the participle agrees in number and gender, while the third and fourth participle are formed from intransitive verbs.

(110) Latvian (lvTenTen14)

[Jūras krasts un kāpas, mežs un pḷavas ir tik labi pazīstami.]

fürmalā

ir

sagaidì-t-i

seaside.LOC.SG

be.PRs.3

welcome-PST.PP-PL.M

neskaitāmi

saulrieti,

vēro- $t$ - $a$

uncountable.NOM.PL.M

sunrise.NOM.P

bangainā

jūra

watch-PST.PP-SG.F

rough.NOM.SG.F.DEF

sea.NOM.sG

vētrā,

$\boldsymbol{s} \overline{\boldsymbol{e}} \boldsymbol{e} \overline{\boldsymbol{e}}-\boldsymbol{t}-\boldsymbol{s} \quad u z$

saules

sit-PST.PP-NA

on

lielajiem

sun.GEN.SG

storm.LOC.SG

big.DAT.PL.M.DEF

akmeñiem

sasildìtajiem

ostas

stone.DAT.PL

warm.DAT.PL.M.DEF

harbour.GEN.sG

molu,

staig $\bar{a}-t-s$

$p a$

ostā

pier.ACC.SG

atgriežas

walk-PST.PP-NA

along

harbour.LOC.SG

return.PRS.3.RFL

skatoties

$k \bar{a}$

kug̣īši.

ship.DIM.NOM.PL

'[The seaside's shore and dunes, forest and meadows are so well known (to me/us).] At the seaside I/we welcomed uncountable sunrises, watched the rough sea during storms, sat on the big stones warmed by the sun, or walked along the harbour pier, watching how fishing boats returned to the harbour.'

With the auxiliary ir (be.PRs.3), the construction formally belongs to the Present Perfect tense in Latvian. This tense is used in the active voice in the clauses that introduce the reminiscence in (110), see (111):

\begin{tabular}{|c|c|c|c|c|c|}
\hline \multirow[t]{9}{*}{$(111)$} & \multicolumn{5}{|c|}{ Latvian (lvTenTen14) } \\
\hline & Daudzus & gadus & \multicolumn{2}{|c|}{ mana } & gimene \\
\hline & many.ACC.PL.M & year.ACC.PL & \multicolumn{2}{|c|}{ my.NOM.SG.F } & family.NOM.SG \\
\hline & vasaras & $i r$ & \multicolumn{2}{|c|}{ pavadījusi } & Zvejniekciema \\
\hline & summer.ACC.PL & be.PRs. 3 & \multicolumn{2}{|c|}{ spend.PST.PA.SG.F } & PLN.GEN \\
\hline & jūrmalā, & tur & \multirow{2}{*}{$\begin{array}{l}\boldsymbol{i r} \\
\text { be.PRS.3 }\end{array}$} & \multicolumn{2}{|c|}{ izauguši } \\
\hline & seaside.LOC.sG & there & & \multicolumn{2}{|c|}{ grow_up.PST.PA.SG.F } \\
\hline & \multicolumn{2}{|c|}{$m \bar{u} s u \quad$ bērni } & un & \multicolumn{2}{|c|}{ mazbērni. } \\
\hline & 1PL.GEN & child.NOM.PL & and & \multicolumn{2}{|c|}{ grandchild.NOM.PL } \\
\hline
\end{tabular}


'For many years my family (has) spent the summers at the seaside of Zvejniekciems. This is where our children and grandchildren grew up.'

As (111) is the beginning of the text, the passive cannot be used-the topical actor (here: the author and her family) has to be introduced first.

It seems that in Latvian there is a stronger bond between type-focusing and perfect tense than in Lithuanian (see also Section 6.3). In Lithuanian, simple past or pluperfect would be the natural tense choice when 'translating' a cumulative construction into active voice, while in Latvian Present Perfect Active, or an active past participle without auxiliary, is also found in cumulative constructions (cf. Nau 2005, there described as 'listings of events'). An alternation of active and passive participles is observed in Latvian when, in a cumulative construction where passive is the main choice, certain predicates cannot be used in the passive. Reasons may be formal (reflexive verbs do not form passive participles in Latvian), lexical (some verbs, probably those that express unrepeatable events, never use a past passive participle as predicate), or semantic (restriction to human actors). Two longer examples shall illustrate this.

Example (112) is a typical part of a report about a person's career. The topical person is Anna, whose career as a singer is introduced in two sentences with past tense (112 a). This introduction is followed by seven clauses listing her achievements, six of which contain a passive participle (of which two combined with the auxiliary ir), but the first one (112 b) has the form of an active Present Perfect, as the verb is reflexive. After the listing, a sentence with past tense concludes the report (112 e).

(112) Latvian (lvTenTen14)

(a) Skrundas sieviešu korī Anna sāka [start.PsT.3] dziedāt 196o. gadā. Deviņdesmitajos gados viņa bija [be.PST.3] viena no piecām visilgāk dziedājušajām kora dalībniecēm.

'Anna started to sing in the women's choir of Skrunda in 1960. During the nineties she was one of the five members who had sung in the choir for the longest time.'

(b) $\mathbf{I r}$

be.PRS. 3

dziesmu song.GEN.PL

(c) apmeklè-t-i

attend-PST.PP-PL.M piedalījusies

take_part.PST.PA.F.RFL svettkos, [...]

festival.LOc.PL

visi

all.NOM.PL.M visos

all.LOC.PL.M

koru

choir.GEN.PL 
salidojumi,

gathering.NOM.PL

(d) dzied $\bar{a}-\boldsymbol{t}-\boldsymbol{s}$

sing-PST.PP-NA

daudzās

dažā $\bar{a} \bar{s}$

vietās un

many.LOC.PL.F various.LOC.PL.F

place.LOC.PL

un dažādām

skatuvēm. [...]

scene.DAT.PL

'(She) took part in all song festivals [...], attended all choir gatherings, sang at many different places and on various scenes.' [omitted: four clauses with passive predicates continuing the list of achievements]

(e) Anna korī dziedāja [sing.PST.3] lìdz 20oo. gadam un to atstāja [leave.PST.3] slimības dēḷ.

'Anna sang in the choir until the year 2000 and left it because of bad health.'

Just as in (110) above, in (112) clauses with a passive predicate referring to the same actor are combined regardless of whether they are subjectless or do have a nominative subject. Each clause starts with the verb. In the first clause, the auxiliary ir 'be.PRs.3' appears and seems to have scope over all following participles, active or passive.

Example (113) illustrates the use of the verbs 'be born' and 'die' in active voice besides other verbs in the passive. This extract is an instance of indefinite actor and the active participles are marked for masculine plural, which is the Latvian version of a third person plural indefinite (for this type see Siewierska \& Papastathi 2011). It is not clear why the verbs dzimt 'be born' and mirt 'die' are never used in the passive in Latvian (in contrast to Lithuanian). Other verbs where the subject is the undergoer do appear in passives, for example, krist 'fall', slimot 'be ill', also verbs implying a change of state (though this is rare) such as aizmigt 'fall asleep'. A possible reason may be the fact that 'die' and 'be born' are not repeatable and not quantifiable-they cannot depict a type of which the same individual can experience more than one token, the situation that may be at the heart of the construction.

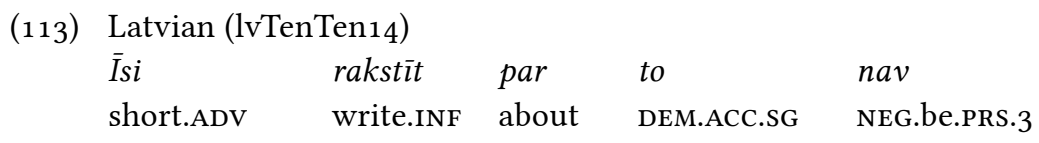




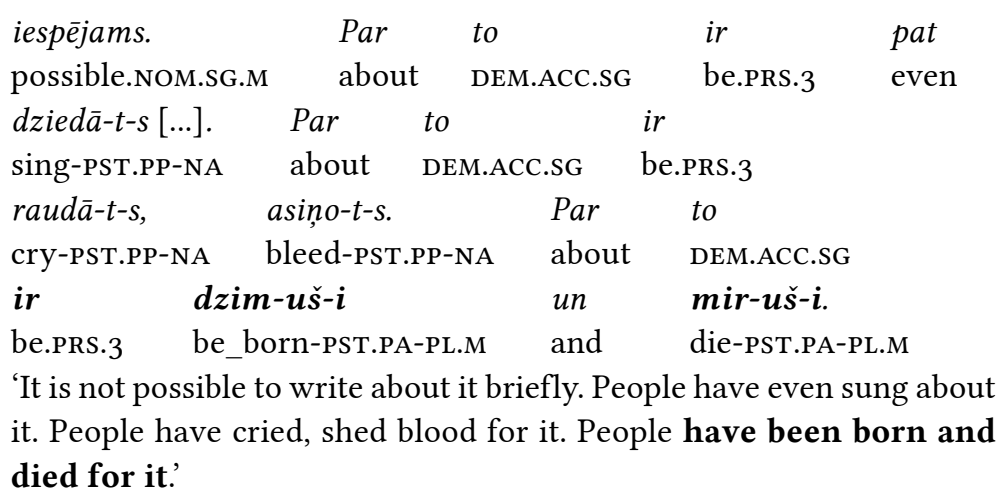

Example (113) is less typical for a cumulative construction, as it lacks explicit quantification. Each of the passive clauses in isolation could refer to just one single event. By being part of a list, and also because of the indefiniteness of the actor, it may however be inferred that events of this type have taken place repeatedly.

Perfect tense seems to be an important ingredient of the cumulative construction in Latvian when understood as a quantification over tokens of an event type indicated by the predicate. In contrast, a past form of the auxiliary tikt 'get' in listings of activities has a different effect: it draws attention to activities carried out on a single occasion. Consider example (114).

(114) Latvian (lvTenTen14)

[Š̄ gada Annas tika piln̄̄bā "iznestas uz Rucavas sievu pleciem”.]

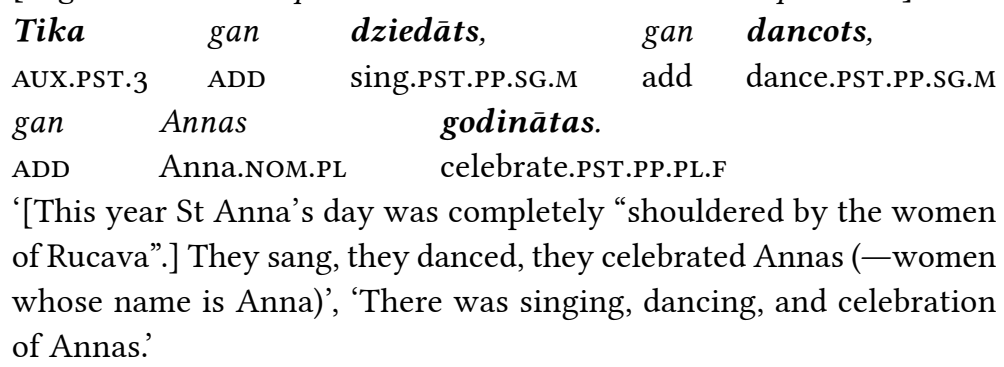

This also is a pattern found several times in the corpus, but it is a functionally and grammatically different kind of listing. The actor is less clearly associated with a known, given referent-in (114), the singing and dancing was probably done not only by the women of Rucava but by everybody attending the event (in this interpretation, a translation into 
German with the impersonal passive would be possible). A similar example with a generic actor was (91) in Section 6.2.1 above.

A possible conclusion is that in Latvian, the cumulative construction with listing of event types is derived from the general function of experiential perfect, to which we will turn in Section 6.3, while listing of events with indefinite or vague actors and the auxiliary tikt as in (114) belong to the general functions of subjectless and subject-weak passives with tikt.

\subsection{Experiential perfect in Latvian}

As stated above, in Latvian the distinction between type-focusing and token-focusing event descriptions (cf. Dahl \& Hedin 200o) is grammaticalized (to a higher degree than in Lithuanian) in the distinction between Simple Past (focusing tokens) and Present Perfect (focusing types). With atelic activities and states - the type of verbs we focused on in our analysis of passives of intransitive verbs - a perfect tense cannot entail the meaning of a resulting state (at least not one directly connected to the verb meaning). Instead, the Present Perfect of these verbs often expresses what has been called EXPERIENTIAL (or EXISTENTIAL) PERFECT or INDEFINITE PAST (Comrie 1976, 58-59; Bybee, Perkins \& Pagliuca 1994, 62; Lindstedt 2000, 369; Iatridou et al. 2003, 155). ${ }^{18}$ There are broader and narrower definitions of this concept, and we may use the different terms to distinguish them. Comrie's definition of the experiential perfect is essentially that of an indefinite past: it "indicates that a given situation has held at least once during some time in the past leading up to the present" (Comrie 1976, 58). It is the narrower definition that deserves the term experiential perfect, for example: "certain qualities or knowledge are attributable to the agent due to past experience" (Bybee, Perkins \& Pagliuca 1994, 63), "asserts that the subject has a certain experience" (Iatridou et al. 2003, 155). As Lindstedt (2000, 369) notes, the narrower definition presupposes an animate agent.

${ }^{18}$ Note that we are talking about an experiential perfect as one use of a gram of the gram-type PERFECT. Some languages have a distinct gram for experiential meaning, which leads to the postulation of a distinct gram-type EXPERIENTIAL (Dahl 1985, 139-144). The Latvian Present Perfect is a typical European perfect similar to the one in English or Swedish. A distinct form for the experiential is a construction containing the past active participle and the auxiliary tikt (see Daugavet \& Holvoet 2019). 
In Latvian we find that the Present Perfect with atelic verbs in the active voice is used as an indefinite past-it meets the broader definition, and the semantic range of subjects is not restricted, while in the passive voice it is restricted to human referents and very often used in the narrower meaning, namely, asserting experiences (or, when used with negation, asserting the lack of experience). As it is mostly individuals whose experience is noteworthy, this type of passive construction is mostly used when the covert actor has a referent known to both speaker and hearer, retrievable from the context and being the topic of the current discourse. However, it is also sometimes found with generic actors, especially in subordinate clauses (for example, of the type If/when one has v-ed...).

We illustrate the experiential perfect with subjectless passives and in the active voice with a longer example, which nicely shows the contrast between perfect and past. Like all examples in this section, (115) comes from the corpus lvTenTen14, but the original text, an interview with the alpinist Kristaps Liepiņš, is still available on the Internet. ${ }^{19}$ In lines (a), (c) and (d) the verb būt 'be' is used in the Present Perfect of the active voice. This part of the extract introduces the topic ('the highest mountains I have climbed') in a general way, while the following lines, where the main predicate is the verb $k \bar{a} p t$ ' $c$ limb'20 or its prefixed lexical synonym $u z k a \bar{p} t$, give examples either as types or as tokens. In line (d), with Present Perfect Active, the speaker's experience with a type of events (climbing high peaks) is asserted, while line (f) gives the example of a specific token of such an event, therefore using Simple Past. The same contrast between event type and asserting experience, on the one hand, and naming a concrete example, on the other, is found in the following lines, (g) and (h) vs. (i). Only here, the passive is used instead of the active in Present Perfect. Thus, we see that active and passive alternate within the Present Perfect, which contrasts with Active Simple Past.

(115) Latvian (lvTenTen14)
(a) Man
bieži
vaicā,
kas
ir
1SG.DAT often
ask.PRS.3
what.NOM
be.PRS. 3

\footnotetext{
${ }^{19}$ http://www.adventurerace.lv/?DocID=1999, accessed 01.07.2020.

${ }^{20}$ Note that this verb is intransitive in Latvian: the goal that is expressed as a direct object in English (climb a mountain) is in the locative in Latvian (kāpt kalnā, literally 'climb on a mountain').
} 
augstākais

highest.NOM.SG.M.DEF

esmu

be.PRS.1SG

bijis?

kalns,

kur

mountain.NOM.SG

where

'I am often asked what the highest mountain is where I have been.'

(b) [Nedaudz pāri sešiem kilometriem. Un tad cilvēks tā skatās: "Mmm, tas jau tā zemu ... Nav jau aston,i.’]

['A little over six kilometres. And then they look at me: "Well, that is rather flat... It isn't eight.”']

(c) $\mathcal{F} \bar{a}$

neesmu bijis

yes

kas

what.NOM

kilometriem.

kilometre.DAT.PL

'True, I have not been on mountains higher than six kilometres.'

(d) bet

30 gadu

laikā

but

30 year.GEN.PL

time.LOC.SG

esmu

kāpis

climb.PST.PP.SG.M

daudzās

many.LOC.PL.F

veida

virsotnēs

dažādās

kind.GEN.SG

peak.LOC.PL

pasaules

malās.

world.GEN.SG

edge.LOC.PL

'but in the course of 30 years I have climbed many other kinds of peaks in various parts of the world.'

(e) [Kurš ir tas sešu kilometru kalns?]

(interviewer) ['Which is this mountain of six kilometres?']

(f) $L \bar{l} d z$

$$
\text { sešiem }
$$

tūkstošiem

uzkāpām

up_to

six.DAT.M

thousand.DAT.PL

PVB.climb.PST.1PL

Pamirā,

tas

bija

sen.

Pamir.LOC

DEM.NOM.SG.M

be.pst 3

long_ago

'We climbed up to six thousand in the Pamir Mountains, that was long ago.'

(g) $I r$

be.PRs. 3

uzkāpts

kas

PVB.climb.PST.PP.NA

arī

also

virsotnēs,

what.NOM

ir

tuvu

be.PRS.3

close sešu

six.GEN
peak.LOC.PL

kilometru

kilometre.GEN.PL 
augstumam Himalajos.

height.DAT.SG Himalaya.LOC.PL

'I/we also (have) climbed peaks with a height close to six kilometres in the Himalayas.'

(h) $\mathbf{I r}$

be.PRs.3

Pamirā

\section{kāpts}

climb.PST.PP.NA piectūkstošniekos

five_thousand.DER.LOC.PL

Pamir.LOC and Africa.LOC

'I/we (have) climbed five-thousand-metres peaks in the Pamir Mountains and in Africa.'

(i) $\bar{A}$ frik $\bar{a}$

Africa.Loc

kāpām

otrajā

kontinenta

climb.PST.1PL

second.LOC.SG

continent.GEN.SG

augstākajā

smaile,

highest.LOC.SG.DEF peak.LOC.SG

[kas no Kilimandžāro atšķiras ar Alpu smailes skatu.]

'In Africa we climbed the continent's second highest peak, [which differs from the Kilimanjaro with (having) a view of Alps' peaks.]'

What then is the function of the passive in this context, or what is the difference between the active clause (115 d) and the passive clauses in (115 $\mathrm{g}, \mathrm{h})$ ? Both the Present Perfect Active and the Passive with the auxiliary $b \bar{u} t$ 'be' in present tense refer to event types with several tokens in an indefinite past (climbing various mountains). As the passive has no explicit mention of the actor, in this example it may refer to actions carried out by the speaker alone or by a group including the speaker. Strictly speaking, $(115 \mathrm{~g}, \mathrm{~h})$ only assert that events of this type have taken place ('there has been climbing of such peaks'), while (115 d) asserts that a named actor has carried out the action ('I have climbed such peaks'). In this way the passive construction highlights the verb without its main argument. Possibly the assertion of the event is therefore stronger in the passive construction. However, a stronger assertion in (115 g, h) may also result from word order, with the verb at the beginning of the clause.

Asserting the actor's experience with a certain type of events often includes quantification: it is asserted that the type has occurred more than once, or with a high intensity. Another typical pattern is listing of different events which together form the experience. Thus, we get what was described as cumulative construction in Section 6.2, but what in Latvian may be better classed as cumulative subtypes of an experiential perfect. 
Example (116) illustrates quantification of a single event type. Examples for listing of event types were given in Section 6.2.

(116) Latvian (lvTenTen14)

$\begin{array}{llll}\text { Ir } & \text { gana } & \text { kris-t} \text {-s, } & \text { vienmēr } \\ \text { be.PRS.3 } & \text { plenty fall-PST.PP-NA } & \text { always } \\ \text { veiksmigi } i & \text { bijis. } & & \\ \text { lucky.ADV } & \text { be.PST.PA.NA } & \end{array}$

'I have fallen down many times, and always been lucky'

Another subtype of the experiential perfect contains negation, as in (117). With negation, the meaning is often that of a UNIVERSAL PERFECT, or PERFECT OF PERSISTENT SITUATION, as it asserts that a state has lasted for a certain period up to the moment of speech. The same holds for an active Present Perfect (118), with which the passive construction alternates. A universal perfect without negation occurs more rarely in both voices.

(117) Latvian (lvTenTen14)

Pēdējos 13 gadus nav slimo-t-s

last.ACC.PL.M 13 year.ACC.PL NEG.be.PRS.3 be_ill-PST.PP-NA 'I haven't been ill for the last 13 years.'

(118) Latvian (lvTenTen14)

$\begin{array}{llll}\text { Šos } & \text { pédējos } & \text { gadus } & \text { neesmu } \\ \text { DEM.ACC.PL.M } & \text { last.ACC.PL.M } & \text { year.ACC.PL } & \text { NEG.be.PRS.1SG } \\ \text { slimojusi } & \text { nevienu } & \text { dienu. } \\ \text { be_ill.PST.PA.SG.F } & \text { NEG.one.ACC.SG day.ACC.SG } \\ \text { 'I haven't been ill a single day for these last years.' }\end{array}$

Thus, the Present Perfect of a subjectless passive in Latvian has the same (temporal) functions as a Present Perfect in the active. The difference between the voices is that the passive is restricted to humans, most often refers to the first person and more often expresses an experiential perfect in the narrow sense (these three features are of course related). As it lacks morphological means of reference tracking, it is used when the referent has already been established in the discourse. It may be vague between 1SG and 1PL (exclusive), cf. examples (115) and (110). Being 'stripped' of its main argument, the verb meaning comes to the fore, which may result in a stronger assertion than that expressed with an Active Present Perfect. However, whether this is a regular difference between the active and the passive construction is not clear; this question needs a separate study with 
native speaker judgements. The active form occurs in all registers, while the passive is rather informal and found especially in blogs and interviews.

\subsection{Conclusions: tendencies and types}

Our investigation of the so-called impersonal passive in Baltic has shown at least two things that challenge previous views, or add important aspects to them. First, we have argued that there is no categorical distinction between 'impersonal' passive (understood as subjectless) and 'personal' passive (where there is or could be a nominative subject). Instead, there are construction types that are characterized by either lacking a subject or having a 'weak' subject. In Lithuanian, weak subjects are usually in a non-nominative case and/or do not trigger agreement; therefore the nonagreement form of the participle is characteristic for these constructions (and they are 'impersonal' if this is the defining criterion). In Latvian, on the other hand, weak subjects are mainly distinguished by word order (they follow the verb) and the fact that they are not topics, but morphologically they are the same as strong subjects, showing nominative case and agreement. Second, it became clear that, however the category is defined, impersonal passives do not represent one single type, but branch into several types with subtypes. We will now summarize the features of those types that may be more clearly distinguished.

The most general of these is the use of subjectless and subject-weak passives with a generic meaning.

Table 17. Generic descriptions (no or weak subject)

\begin{tabular}{|c|c|c|}
\hline Feature & Latvian & Lithuanian \\
\hline Participle & PST-PP ( $t$-participle) & both, mostly $m$-participle \\
\hline Auxiliary & most common with tikt & būti or no auxiliary \\
\hline Actor & $\begin{array}{l}\text { human; people at a cer- } \\
\text { tain place or time }\end{array}$ & $\begin{array}{l}\text { human; people at a cer- } \\
\text { tain place or time }\end{array}$ \\
\hline Agent phrase & - & $\begin{array}{l}\text { not possible with } \\
m \text {-participle, rare } \\
\text { with } t \text {-participle }\end{array}$ \\
\hline
\end{tabular}




\begin{tabular}{lll} 
Feature & Latvian & Lithuanian \\
Meaning & $\begin{array}{l}\text { description of typical, } \\
\text { regular activities of all } \\
\text { members of a large group } \\
\text { (unspecific events) }\end{array}$ & $\begin{array}{l}\text { description of typical, } \\
\text { regular activities of all } \\
\text { members of a large group } \\
\text { (unspecific events) }\end{array}$ \\
\hline Verbs (semantic) & $\begin{array}{l}\text { typically agentive, } \\
\text { activities }\end{array}$ & $\begin{array}{l}\text { typically agentive, activi- } \\
\text { ties }\end{array}$ \\
Verbs (transitivity) & intransitive or transitive & $\begin{array}{l}\text { mostly intransitive; } \\
\text { transitives occasionally } \\
\text { occur }\end{array}$ \\
\hline Word order & $\begin{array}{l}\text { weak subject follows } \\
\text { verb }\end{array}$ & various \\
Tense, mood & present or past tense & $\begin{array}{l}\text { mostly present; past and } \\
\text { future possible }\end{array}$ \\
\hline Registers & all & all
\end{tabular}

Our next construction type is what we call the 'cumulative construction'. It seems to have several varieties. The 'cumulative-retrospective' construction is most clearly distinguished in Lithuanian. It also appears in Latvian, but for Latvian another variant, the 'cumulative-experiential', is more typical. The two subtypes are compared in Table 18 . The cumulativeexperiential construction may also be seen as a subtype of the experiential perfect summarized in Table 19.

Table 18. Cumulative constructions typical for Lithuanian and Latvian compared (the Lithuanian type occurs also in Latvian, but is less typical there)

\section{Cumulative-retrospective Cumulative-experiential construction (typical for construction (typical for Lithuanian)}

\begin{tabular}{lll} 
Participle & $\begin{array}{l}\text { PST-PP }(t \text {-participle); } \\
\text { almost always non-agree- } \\
\text { ment form }\end{array}$ & PST-PP ( $t$-participle) \\
Auxiliary & $\begin{array}{l}\text { usually without auxiliary; } \\
\text { if auxiliary occurs, it is in } \\
\text { past tense }\end{array}$ & $\begin{array}{l}\text { 'be' typically appears and is } \\
\text { in present tense }\end{array}$ \\
Actor & $\begin{array}{l}\text { human; usually known, } \\
\text { third or first person }\end{array}$ & $\begin{array}{l}\text { human; usually known, most } \\
\text { often first person }\end{array}$ \\
\hline
\end{tabular}




\section{Cumulative-retrospective Cumulative-experiential construction (typical for construction (typical for Lithuanian) \\ Latvian)}

Agent phrase possible

Meaning

habitual past, cumulative action(s) experiential perfect; event types which have occurred in the past; attesting agent's experience or achievements

agentive and non-agentive; activities and states; rare with change-of-state verbs agentive and non-agentive; activities and states

\begin{tabular}{|c|c|c|}
\hline $\begin{array}{l}\text { Verbs } \\
\text { (transitivity) }\end{array}$ & $\begin{array}{l}\text { predominantly intransitive; } \\
\text { transitives occasionally occur }\end{array}$ & $\begin{array}{l}\text { intransitive and transitive; } \\
\text { transitives often occur }\end{array}$ \\
\hline $\begin{array}{l}\text { Subjects/ } \\
\text { Objects }\end{array}$ & $\begin{array}{l}\text { predominantly without } \\
\text { subject; if subject occurs, } \\
\text { it is typically quantified, } \\
\text { genitive marked; possible, } \\
\text { but rarely attested: direct } \\
\text { object not promoted }\end{array}$ & $\begin{array}{l}\text { nominative subjects with } \\
\text { transitive verbs common }\end{array}$ \\
\hline Word order & $\begin{array}{l}\text { various; sentence-initial } \\
\text { adverbial is common }\end{array}$ & $\begin{array}{l}\text { verb at the beginning } \\
\text { of clause }\end{array}$ \\
\hline Tense, mood & indicative past tense & present perfect \\
\hline Registers & $\begin{array}{l}\text { typical for certain registers: } \\
\text { media, blogs, fiction }\end{array}$ & $\begin{array}{l}\text { typical for certain registers: } \\
\text { media, blogs, fiction }\end{array}$ \\
\hline
\end{tabular}

Table 19. Experiential perfect with the passive in Latvian

\begin{tabular}{ll} 
Feature & Value \\
\hline Participle & PST-PP ( $t$-participle) \\
\hline Auxiliary & 'be' (in present tense) or no auxiliary \\
\hline Actor & human; most often first person \\
\hline
\end{tabular}




\begin{tabular}{ll} 
Feature & Value \\
\hline Meaning & $\begin{array}{l}\text { experiential perfect: states that a token of an } \\
\text { event type took place in the past and attests the } \\
\text { agent's experience }\end{array}$ \\
\hline Verbs (transitivity) & intransitive and transitive \\
\hline Verbs (semantic) & agentive and non-agentive \\
\hline Word order & verb typically clause-initially \\
\hline Tense, mood & $\begin{array}{l}\text { perfect; alternates with active present perfect and } \\
\text { is opposed to simple past tense }\end{array}$ \\
\hline Registers & typical for blogs, personal reports, also interviews
\end{tabular}

\section{Evidential meaning, evidentials and evidential passive}

In Latvian, a bare past participle, active or passive, is often used in reports and contexts of hearsay. They can be interpreted as past tense forms of the Evidential, which in present tense has a special form with the suffix -ot (historically a present active participle). A passive participle of an intransitive verb is usually pragmatically bound to the topical person of the report, while an active participle can be used with any overt or covert subject. In (119), the whole extract is marked for reported evidentiality by the choice of verb forms.

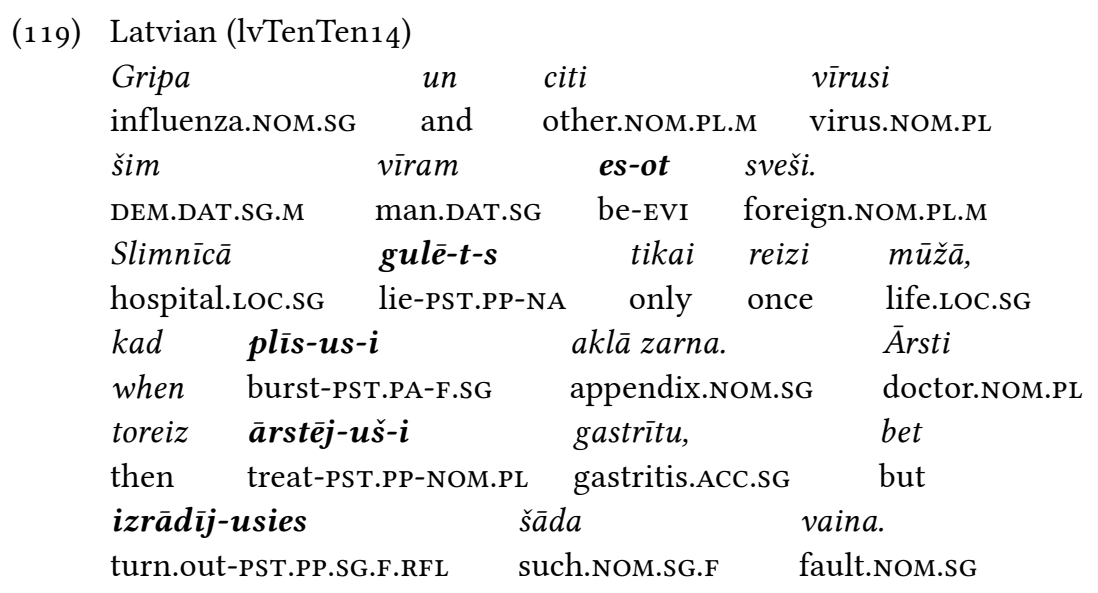


'Influenza and other viruses are alien to this man. Only once in (his) life (he = this man) had been to hospital, when he had appendicitis.' (literally: 'when the appendix (had) burst') The doctors at the time medicated him for gastritis, but it turned out to be that fault (appendicitis).'

However, this use of the passive participles as evidentials is not fully grammaticalized. Bare participles are also used in other functions, especially for indicating anteriority, or as experiential perfects (see 6.3). The use in evidential meaning differs from other uses of the participle in allowing definite time reference and in that it can be used in narratives, though this is not frequent in modern standard Latvian. With certain verbs, the evidential use seems to be more frequent than average. One such verb is varèt 'can, be able', as in (120) (cf. Holvoet 2015, 388-390). With this verb, the actor is most often generic or indefinite, not a topical or first person. Thus, the two predicates in the form of past passive participles in (120) have different actors.

(120) Latvian (lvTenTen14)

\begin{tabular}{|c|c|c|c|c|}
\hline $\begin{array}{l}\text { Dzirde-et-s, } \\
\text { hear-PST.PP-NA }\end{array}$ & $\begin{array}{ll}k a & a g r a \bar{k} \\
\text { that } & \text { earlier }\end{array}$ & $\begin{array}{l}\text { Fal } \\
\text { PLI }\end{array}$ & oku & $\begin{array}{l}\text { Jaunpils } \\
\text { PLN.GEN.SG }\end{array}$ \\
\hline pilīs & $\operatorname{var} \bar{e}-t-s$ & gan & sarakstīties, & gan \\
\hline $\begin{array}{l}\text { castle.LOC.PL } \\
\text { svinēt. }\end{array}$ & can-PST.PP-NA & $\mathrm{ADD}$ & marry.INF.RFL & $\mathrm{ADD}$ \\
\hline
\end{tabular}

'I heard that earlier in the castles of Jaunmokas and Jaunpils one could get married as well as have a party.'

Lithuanian has gone much further in the grammaticalization of a passive construction into an Evidential, and the remainder of this section will deal with Lithuanian exclusively.

\subsection{The Lithuanian Evidential}

As is well known from the literature, the Lithuanian impersonal passive has developed extended uses; more specifically, it has moved into the domain of evidentiality. The evidential (inferential) meaning initially rested on implicature which later on became more and more conventionalized (Wiemer, forthcoming). This gave rise to a new construction which, 
although based on non-agreeing passive participles, is in many respects distinct from the impersonal passive.

Several scholars have presented arguments against a passive analysis of the evidential construction; we will briefly present these here.

Firstly, a personal passive can serve as an input to an evidential, cf. (121), where (121b) is derived from (121a).

(121) Lithuanian (cited from Spraunienè et al. 2015)
(a) fis
buvo
muš-t-as.
3.NOM.SG.M be.PST.3
beat-PST.PP-SG.M
'He was beaten.'
(b) 70
$b \bar{u}-t-a$
3SG.GEN.M
be-PST.PP-NA
muš-t-o.
'He was beaten (apparently).'
beat-PST.PP-GEN.SG.M

If passivization is understood as an operation which demotes or deletes the agent (or the most agent-like argument), then double passivization should be precluded.

Secondly, evidentials with non-agreeing participles do not impose any restrictions on the lexical input to the construction; e.g. they may be formed from zero-place verbs such as lyti 'rain' and epistemic modals which, as raising verbs, do not have an argument structure of their own and therefore should not allow passivization (Nau \& Holvoet 2015; Sprauniene et al. 2015; Wiemer 2006b, 301); cf. (122) and (123).
(122) Lithuanian (DLKT)

$\begin{array}{llll}\text { Nakti } & \text { smarkiai } & \boldsymbol{l} \boldsymbol{y}-\boldsymbol{t}-\boldsymbol{a}, & \text { žole } \\ \text { night.ACC.SG } & \text { heavily } & \text { rain-PST.PP-NA } & \text { grass.NOM.SG } \\ \text { su didele } & \text { rasa. } & \end{array}$

with big.INS.SG.F dew(F).INS.SG
'It rained heavily at night: the dew is heavy on the grass.'
(123) Lithuanian (cited from Spraunienè et al. 2015, 342)

$\begin{array}{llcc}\text { Spèj- } a-m-a, & k a d \quad \text { čia } & \text { gale- } \boldsymbol{t}-\boldsymbol{a} & b \bar{u} t i \\ \text { believe-PRS-PP-NA } & \text { that here } & \text { can-PST.PP-NA } & \text { be.INF } \\ \text { pirmosios } & \text { Kédainiu } & \text { rotušès } & \\ \text { first.GEN.SG.F.DEF } & \text { Kèdainiai.GEN.PL } & \text { town_hall(F).GEN.SG }\end{array}$

'It is believed that the first Town Hall of Kedainiai could have been there.'

Evidential constructions are so distinct from the passive proper that they should be considered non-passive (cf. Lavine 2006; Holvoet 2007; Nau 
\& Holvoet 2015, 18). As observed by other authors (cf. Wiemer 2006a, 35), evidential constructions operate almost exclusively on the non-agreeing form of the $t$-participle, with the exception of the $m$-participle of the verb $b \bar{u} t i$ 'be' which may convey evidential meaning:

(124) Lithuanian (DLKT)

Antpečiu
epaulette.GEN.PL
es- $\boldsymbol{a}-\boldsymbol{m}-\boldsymbol{a}$

žvaigždutès rodo, kad jo

es-a-m-a

star.NOM.PL

show.PRS.3 that

3.GEN.M

be-PRS-PP-NA

leitenanto.

'The epaulette stars show that he must be a lieutenant.'

The evidential construction has further formal and semantic properties which distinguish it from other constructions with a non-agreeing $t$-participle. The following three properties are necessary and defining for the evidential construction:

i. the participle appears without auxiliary and functions as a finite verb (cf. Holvoet 2007, 81-105);

ii. the agent (if there is one) is obligatorily expressed and marked with the genitive;

iii. the construction has evidential meaning (see below).

The genitive of agent exhibits some subject properties, for example, it can trigger predicative agreement in gender, number and case, as illustrated in (125); see also (121b).

(125) Lithuanian (Lithuanian WaC v2)

$\begin{array}{lll}\begin{array}{l}\text { Baudžiauninko } \quad \boldsymbol{b} \overline{\boldsymbol{u}}-\boldsymbol{t}-\boldsymbol{a} \\ \text { be-PST.PP-NA }\end{array} & \begin{array}{l}\text { gudraus } \\ \text { clever.gen.SG.M }\end{array} \\ \text { 'Evidently, the serf was clever' } & \end{array}$

The lexical input of the evidential construction is mostly intransitive verbs with no restrictions on the semantics of the single argument-it may be human, animate, or inanimate. In this respect evidential constructions clearly differ from impersonal passives, which require that the demoted agent is human (see Section 6; Holvoet 2004, 118-119).

Following Lavine (2006), we believe that in evidential constructions, the genitive of agent is most plausibly analysed as a quirky subject of an active construction. The genitival NP is normally used preverbally (as in ex. (125)), but it may also appear in the focus position: 
(126) Lithuanian (DLKT)

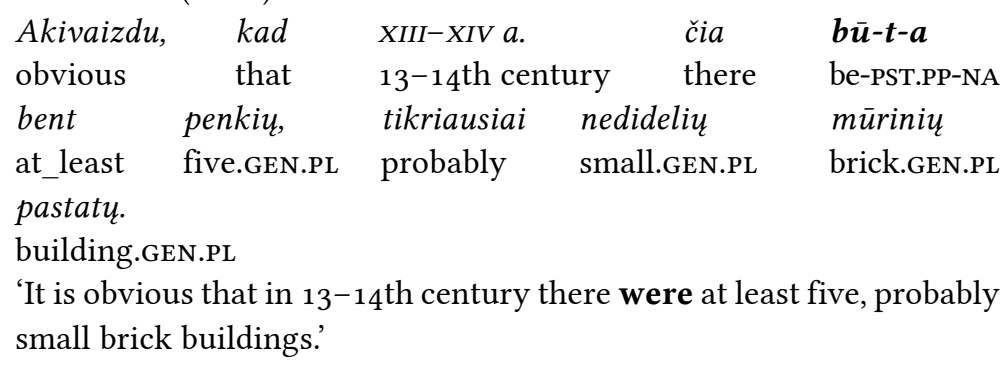

While in Latvian, the Evidential and evidential uses of the participles are specialized for reportative evidentiality, Lithuanian evidential constructions can express different evidential meanings, as illustrated in ex. (127-129) (cf. Ambrazas et al. 2006, 281; Holvoet 2007, 90).

\section{a) inferential:}

(127) Lithuanian (Lithuanian $\mathrm{WaC} \mathrm{v2)}$

[Sprendžiant iš archeologiniu iškasenu,]

Indijos teritorijoje žmoniu gyven-t-a

India.GEN.SG territory.LOC.SG people[PL].GEN live-PST.PP-NA jau paleolite.

already Paleolithic.LOc.sG

'[Judging from the archeological finds,] people already lived in the territory of India in the Paleolithic Age.'

b) reportative:

(128) Lithuanian (Lithuanian WaC v2)

\begin{tabular}{|c|c|c|c|}
\hline $\begin{array}{l}\text { Pasak } \\
\text { according_to }\end{array}$ & $\begin{array}{l}\text { M. Dilienès, } \\
\text { PN.GEN }\end{array}$ & $\begin{array}{l}\text { kariuomeness } \\
\text { army.GEN.sG }\end{array}$ & $\begin{array}{l}\boldsymbol{b} \overline{\boldsymbol{u}}-\boldsymbol{t}-\boldsymbol{a} \\
\text { be-PST.PP-NA }\end{array}$ \\
\hline $\begin{array}{ll}\text { kaip miško. } & \\
\text { as } & \text { forest. }\end{array}$ & N.SG & & \\
\hline
\end{tabular}

'According to M. Dilienè, the army must have been like a forest.'

c) mirative:

(129) Lithuanian (cited from Holvoet 2007, 90)

$\begin{array}{lcll}\text { Užeinu, } & \text { o } & \text { jos } & \text { jau } \\ \text { drop_in.PRS1.SG } & \text { but } & \text { 3.GEN.SG.F } & \text { already } \\ \text { miškan } & \text { išei-t-a. } & & \\ \text { wood.ILL.SG } & \text { go_out-PST.PP-NA } & \end{array}$

'I drop in, but she (it turns out, to my surprise) is gone to the woods.' 


\subsection{Evidential passive}

Though we have attempted to delimit evidential constructions from the passive proper, the boundaries between the evidential and the passive in Lithuanian are fuzzy (cf. Sprauniene et al. 2015). On the one hand there are constructions with $t$-participles which have the formal properties of the evidential but do not convey evidential meaning. Clear examples are the cumulative constructions discussed in Section 6.3. On the other hand, there are impersonal passives which do not meet either the requirement (i) or the requirement (ii) of evidentials but nevertheless have an evidential meaning:

Non-omitted auxiliary, omitted genitive of agent:

(130) Lithuanian (Lithuanian $\mathrm{WaC}$ v2)

$\begin{array}{llll}\text { Ten } \quad \text { kur } & \text { XII-XIII } a . & \text { buvo } & \text { tankiai } \\ \text { there where } & 12 \text { th-13th c. } & \text { be.PST.3 } & \text { densily } \\ \text { gyven-t-a, } & \text { atsirado } & \text { dykros, } & \\ \text { live-PST.PP-NA } & \text { appear.PST.3 } & \text { uninhabited_area.NOM.PL } \\ \text { [XIV a. pietinése } & \text { kuršiu žemése ir Lamatoje liko nedaug kaimu. }\end{array}$

'Those places which were densely inhabited in the $12-13^{\text {th }}$ centuries, turned into uninhabited areas; [in the 14th century in the southern Curonian land and in Lamata there were not so many villages left.]'

(131) Lithuanian (Lithuanian $\mathrm{WaC}$ v2)

$\begin{array}{lllrlr}\text { Kad čia } & \text { nuo } & \text { seno } & \text { buvo } & \text { gyven-a-m-a } \\ \text { that } & \text { here } & \text { since } & \text { old.GEN.SG } & \text { be.PST3 } & \text { live-PRS-PP-NA } \\ \text { byloja } & & \text { dideli, } & \text { gerai } & \text { išsilaike } \\ \text { witness.PRS.3 } & \text { big.NOM.PL.M } & \text { well } & \text { preserved.NOM.PL.M }\end{array}$
futoniu, Žingiu, Degsnès pilkapynai. PLN.GEN PLN.GEN PLN.GEN tumulus(M).NOM.PL

'One can see from the well-preserved tumuli of Jutonys, Žingiai and Degsne that this place has been inhabited since early ages.'

Omitted auxiliary, omitted genitive of agent:

(132) Lithuanian (Lithuanian $\mathrm{WaC}$ v2)

\begin{tabular}{lllll} 
Bet & yra & ženklu, & kad & Gedimino \\
but & be.PRS3 & sign.GEN.PL & that & Gediminas.GEN \\
kalne & \multicolumn{1}{c}{ gyven- $\boldsymbol{t}$ - $\boldsymbol{a}$} & net & $I$ \\
hill.GEN.SG & live-PST.PP-NA even & first \\
tūkstantmetyje & prieš Kristu. & \\
millennium.LOC.SG & B.C.
\end{tabular}


'But there are signs that around Gedimino hill people lived even in the first millennium B.C.'

We would regard ex. (130-132) as EVIDENTIAL PASSIVES, a variety of the impersonal passive which does not have dedicated formal means of expression. Many authors (cf. Willett 1988; Lavine 2006; Wiemer 2006a; Holvoet 2007; Nau \& Holvoet 2015, 18) acknowledge that evidentiality is a parasitical category feeding on other grammatical categories, such as voice, tense and aspect.

As far as lexical input is concerned, it is noteworthy that evidential passives, like evidential constructions and unlike the impersonal passive, can be formed from verbs which do not have human subjects, cf. (133) which refers to the growth of a company's sales:

(133) Lithuanian (DLKT)

$\begin{array}{llll}\text { Vasari } & \text { buvo } & \text { aug-t-a } & \text { dar } \\ \text { February.ACC } & \text { be.PST3 } & \text { grow-PST.PP-NA } & \text { even } \\ \text { smarkiau - } & & & \\ \text { big.сOMP } & & & \end{array}$

[pardavimai pasieke 5,608 mln. Lt ir dvigubai viršijo $2005 \mathrm{~m}$. vasario rodiklius.]'In February the growth was even bigger-[the sales reached 5.608 mln. Litas and doubled the indicators of February 2005.]'

The common and distinguishing features of the Lithuanian Evidential and Evidential Passive are presented in Table 20.

Table 2o. Lithuanian Evidential vs. Evidential passive

\begin{tabular}{lll} 
& Evidential & Evidential Passive \\
Participle & $\begin{array}{l}\text { PST.PP (only with 'be' } \\
\text { also PRS.PP) } \\
\text { non-agreement form }\end{array}$ & $\begin{array}{l}\text { PST.PP, PRS.PP } \\
\text { non-agreement form }\end{array}$ \\
\hline Auxiliary & no auxiliary & $+/-$ \\
Subject & $\begin{array}{l}\text { rare, analyzable as non- } \\
\text { canonical object }\end{array}$ & - \\
\hline Agent & $\begin{array}{l}\text { obligatory; analyzable as } \\
\text { quirky subject }\end{array}$ & $+/-$ \\
\hline Meaning & $\begin{array}{l}\text { evidential: inferential, } \\
\text { reportative, mirative }\end{array}$ & evidential \\
\hline
\end{tabular}




\section{Evidential}

\begin{tabular}{lll} 
Verbs (transitivity) & mostly intransitive & intransitive \\
\hline Verbs (semantic) & all kinds & all kinds \\
\hline Actor & all kinds & all kinds \\
Word order & various & various \\
Registers & all kinds & all kinds
\end{tabular}

\section{Conclusions}

The aim of this paper was to distinguish and 'profile' passive and formally related constructions in Baltic. For this purpose, we used a set of formal and functional parameters, considerably exceeding the syntactic features that are usually the focus of descriptions of the passive. We see multiple connections between the constructions so distinguished, and speak of them as a family of constructions: The Passive Family. We did not identify a progenitor of this family. First, because our study is strictly synchronic, based on corpus data of Modern Standard Latvian and Lithuanian. Second, given the variety of morphological input (two different participles, two different auxiliaries), it is evident that the various members of the Passive Family do not go back to one common ancestor. In our case, the source domain of the family metaphor is not the biological family, but rather the modern patchwork family, which mixes people related by blood, by marriage, and by affinity.

It is also not possible to identify one center or prototype within our motley assemblage. Formally, the $t$-participle and the $m$-participle provide two different starting points, and within one language they are clearly distinguished. In Lithuanian, construction types have a distinct preference for one of the participles, but some types allow both. In Latvian, most constructions investigated here use the $t$-participle, while the $m$-participle is specialized for modal meanings. Constructions with the auxiliary tikt (< 'become; get to') in Latvian may be seen as a third center, a strong stem in the family, which has however not (yet) branched, maybe because it is too young. These constructions represent the most 
typical passive, a 'pure' passive without special temporal or modal meaning, which is actional and clearly verbal (see Section 3). It represents the BASIC PASSIVE as described by Keenan \& Dryer (2007) very well. The Lithuanian equivalent is formally split between the $m$-participle and the $t$-participle (Section 4.1), and constructions with the latter are formally not clearly distinguished from non-actional types of the passive. For these reasons, we did not establish a profile of the actional passive in Lithuanian. There seems to be not one typical passive construction in Lithuanian, but rather several subtypes or patterns specialized (in the sense of strong tendencies) for features such as actionality, tense, and reference type of the deleted actor. Taken together, these patterns may be regarded as representing not only Keenan \& Dryer's basic passive, but also a PROTOTYPICAL PASSIVE in the approach of Siewierska \& Bakker (2012), distinguished by the possibility of expressing the demoted actor in an agent phrase, a possibility only marginally given in Latvian. However, also in Lithuanian this possibility is rarely used in actual texts, where agent phrases occur in less than $10 \%$ of passive constructions (cf. Sections 2.2 and 4.1).

While Latvian and Lithuanian differ considerably in their expressions of an actional passive, they are astonishingly similar with respect to the stative passive and its subtypes (Section 5). These constructions are probably the oldest and represent common heritage in the two Baltic languages (and beyond), but it is still surprising that this remote common heritage has remained so stable amidst many language-particular innovations in the passive domain. In general, in these constructions a subject, which usually is the topic, is characterized by the state expressed by the participle. They may be seen as copular constructions rather than verbal forms, but such a distinction is probably of no further importance. The pure stative passive, or resultative proper (type 'the invoice is lost'), is formed from telic verbs and does not allow an agent phrase (5.1). An oblique argument similar to an agent phrase is possible, and sometimes obligatory, in quasi-resultatives ('the streets are covered by/with snow', 5.2) and qualitative resultatives ('the play is written by me', 5.3), which also differ in the range of possible verbs, showing lexical restrictions. Following Nedjalkov \& Jaxontov (1988), we call these agent phrases "agentive objectives". They are similar to agent phrases expressing demoted actors in passive constructions and provide the source for the development of 
the latter, a process that took place in Lithuanian, but not in Latvian. Lithuanian is unusual in allowing agent phrases even with impersonal passives, though they are found still less often than with passives that have a subject.

We have argued that a simple dichotomy between impersonal and personal, or subjectful and subjectless passives is too narrow a view for a typology of passive constructions in Baltic. First, it is not a trivial question what should count as a subject in the passive (2.3). We argue that besides nominative noun phrases that trigger agreement, quantified nouns and some non-nominal arguments may make a passive construction 'subjectful'. On the other hand, especially in Latvian we see that passive constructions which do have an agreeing nominative subject may behave like impersonal passives, if the subject is indefinite and follows the verb. This made us introduce the concept of 'weak subject', which admittedly needs further specification (left for the future). The concept is useful in the description of those passive constructions which are typical for intransitive verbs, but also found with transitive verbs if the subject is omitted or weak. In Section 6 we described general characteristics of constructions of subjectless and subject-weak passives and profiled some of its types. Of special interest is the cumulative construction, which contains predicates (typically more than one) which are quantified with respect to the occurrence, duration, or intensity of the event. In Lithuanian, the construction has a past-habitual meaning, while in Latvian, cumulative constructions are a subtype of the experiential perfect. In both languages, the actor most often is a known, definite person, which contrasts with the generic human actor that characterizes other passive constructions with intransitive verbs. Although the actor is known, in Lithuanian it may be additionally given in an agent phrase. The undergoer is usually deleted or a weak subject, but in Lithuanian it may also occur as a non-promoted accusative object (very rarely found). The alternation of nominative subjects and non-promoted objects is more typical for another construction in Lithuanian, Subject Impersonals (Section 4.2), which are formed from transitive verbs and have a present-habitual meaning. In Section 6, but also in other parts of our studies, we saw connections between passive constructions and temporal and aspectual meanings. These certainly deserve more investigations, focusing on individual construction types. 
Other meanings that passive constructions may acquire belong to the domains of modality and evidentiality, and the Baltic languages show how the same situation can lead to new developments in one language but not the other. Constructions with the $m$-participle may have vague modal meanings in both languages, but these get more pronounced in Latvian, while Lithuanian develops a more general, often generic passive construction (4.3). On the other hand, only Lithuanian develops a fully grammaticalized evidential construction with the $t$-participle, which in Latvian only in certain contexts has an evidential (reportative or hearsay) meaning (Section 7).

In this paper we have enriched known facts about the passive in Baltic with some new analyses based on data from contemporary corpora of Latvian and Lithuanian. While the types that we described in the sections of this paper may deserve more investigation and individual publications, their treatment in one place and their profiling according to common criteria help to see the family in its entirety and will be useful as a point of departure for further synchronic and diachronic studies.

\section{ABbreviations}

1 - first person, 3 - third person, ACC - accusative, ADD - additive (particle), AUX - auxiliary, ADV - adverb, COMP - comparative, cVB - converb, DAT - dative, DEB - debitive, DEF - definite, DEM - demonstrative, DER - derivational suffix, DIM - diminutive, EVI - evidential, F - feminine, FUT - future, GEN - genitive, GDV - gerundive, IDF - indefinite, ILL - illative, INF - infinitive, INS - instrumental, IRR - irrealis, LOC - locative, $\mathrm{M}$ - masculine, NA - non-agreement form (in Lithuanian and Latvian), NEG - negation, NOM - nominative, PA - active participle, PL - plural, PLN - place name, PN - proper name, POSS - possessive, PP - passive participle, PRS - present, PST - past, PTC - particle, PTCPL - participle, PVB - preverb, REL - relative pronoun, RFL - reflexive, RPOSS - reflexive possessive pronoun, SG - singular

\section{Sources}

DLKT = Dabartinės lietuvių kalbos tekstynas, http://tekstynas.vdu.lt/tekstynas, corpus.vdu.lt

LiLa = Lithuanian-Latvian-Lithuanian Parallel Corpus, https://klc.vdu.lt/en/ lila-parallel-corpus/ 
LithuanianWaC v2 = Lithuanian Web Corpus v2, https:/www.sketchengine. eu/lithuanian-wac/

ltTenTen14 = Lithuanian Web Corpus, https://www.sketchengine.eu/lttentenlithuanian-corpus/

LVK2018 = Balanced Corpus of Modern Latvian, http://www.korpuss.lv/id/ LVK2018

lvTenTen14 = Latvian Web Corpus, https://www.sketchengine.eu/lvtentenlatvian-corpus/

\section{REFERENCES}

Ambrazas, Vytautas. 1990. Sravnitel'nyj sintaksis pričastij baltijskix jazykov [Comparative Syntax of Participles in Baltic Languages].

Vilnius: Mokslas.

Ambrazas, Vytautas et al. 2006. Lithuanian Grammar. Second revised edition. Vilnius: Baltos lankos.

Anderson, Cori. 2015. Passivization and argument structure in Lithuanian. In: Axel Holvoet \& Nicole Nau, eds., Voice and Argument Structure in Baltic. Amsterdam-Philadelphia: John Benjamins, 289-322.

Blevins, James P. 2003. Passives and impersonals. fournal of Linguistics 39, 473-520.

Bybee, Joan, Revere Perkins \& William Pagliuca. 1994. The Evolution of Grammar: Tense, Aspect, and Modality in the Languages of the World. Chicago-London: University of Chicago Press.

Comrie, Bernard. 1976. Aspect. Cambridge: Cambridge University Press.

Dahl, Östen. 1985. Tense and Aspect Systems. Oxford, New York: Blackwell.

Dahl, Östen \& Eva Hedin. 2000. Current relevance and event reference. In: Östen Dahl, ed., Tense and Aspect in the Languages of Europe. Berlin: Mouton de Gruyter, 385-401.

Daugavet, Anna \& Axel Holvoet. 2019. An elusive experiential tense construction in Latvian. Baltic Linguistics 10: Minor Grams in Baltic, Slavonic and Fennic (thematic issue), 109-153.

EndZELIn, J[ĀnIs]. 1923. Lettische Grammatik. Heidelberg: Winter.

Frajzyngier, Zygmunt. 1982. Indefinite agent, impersonal, and passive: A functional approach. Lingua 58, 267-290. 
Geniušiené, Emma Š. 2006. Passives in Lithuanian (in comparison with Russian). In: Werner Abraham \& Larisa Leisiö, eds., Passivization and Typology: Form and Function. Amsterdam-Philadelphia: John Benjamins, 29-61.

Geniušienė, Emma Š. 2016. Passive Constructions in Lithuanian. Selected Works of Emma Geniušiene, edited by Anna Kibort \& Nijolè Maskaliūnienè. Amsterdam-Philadelphia: John Benjamins.

Geniušienė, Emma Š., Vladimir P. Nedjalkov. 1988. Resultative, passive, and perfect in Lithuanian. In: Vladimir P. Nedjalkov, ed., Typology of Resultative Constructions. Amsterdam-Philadelphia: John Benjamins, 369-386.

Holvoet, Axel. 2001a. Impersonals and passives in Baltic and Finnic. In: Östen Dahl \& Maria Koptjevskaja-Tamm, eds., Circum-Baltic Languages. Vol. 2: Grammar and Typology. Amsterdam-Philadelphia: John Benjamins, 363-389.

Holvoet, Axel. 2001b. Studies in the Latvian Verb. Kraków: Wydawnictwo Uniwersytetu Jagiellońskiego.

Holvoet, Axel. 2004. Eine modale Konstruktion ostseefinnischer Herkunft im Lettischen. In: Irma Hyvärinen, Petri Kallio \& Jarmo Korhonen, eds., Etymologie, Entlehnungen und Entwicklungen. Festschrift für forma Koivulehto zum 7o. Geburtstag. Helsinki: Société Néophilologique, 117-127.

Holvoet, Axel. 2007. Mood and modality in Baltic. Kraków: Wydawnictwo Uniwersytetu Jagiellońskiego.

Holvoet, Axel. 2015. Latvian passives-personal, impersonal and evidential. In: Axel Holvoet \& Nicole Nau, eds., Voice and Argument Structure in Baltic. Amsterdam-Philadelphia: John Benjamins, 367-394.

Holvoet, Axel. 2020. The Middle Voice in Baltic. AmsterdamPhiladelphia: John Benjamins.

Holvoet, Axel \& Loreta Seménienė. 2004. Linksnio teorijos pagrindai [The foundations of the theory of Case]. In: Axel Holvoet \& Loreta Semènienè, eds., Gramatiniu kategoriju tyrimai. Lietuviu kalbos gramatikos darbai 2 [Studies in Grammatical Categories. Studies in Lithuanian Grammar 2]. Vilnius: Lietuvių kalbos institutas, 11-33.

Holvoet, Axel, Birutė Spraunienè, Anna Daugavet \& Asta Laugaliené. 2019. The agentive construction in Baltic and Fennic. Baltic Linguistics 10: Minor Grams in Baltic, Slavonic and Fennic (thematic issue), 195-236. 
Iatridou, Sabine, Elena Anagnostopoulou \& Roumyana Izvorski. 2003. Observations about the form and meaning of the Perfect. In: Artemis Alexiadou, Monika Rathert \& Arnim von Stechow, eds., Perfect Explorations. Berlin: de Gruyter Mouton, 153-204.

Keenan, Edward L. \& Matthew S. Dryer. 2007. Passive in the world's languages. In: Timothy Shopen, ed., Language Typology and Syntactic Description, second edition, Vol. I: Clause Structure. Cambridge: Cambridge University Press, 325-361.

LaAnemets, Anu. 2012. Passiv i moderne dansk, norsk og svensk. Et korpusbaseret studie af tale-og skriftsprog [The Passive in modern Danish, Norwegian and Swedish. A Corpus-Based Study of Spoken and Written Language]. Doctoral dissertation. University of Tartu Press.

LAVINE, JAMES E. 2006. Is there a passive evidential strategy in Lithuanian? In: Jacqueline Bunting et al., eds., Papers from the 42 nd Meeting of the Chicago Linguistic Society, 41-55.

LindstedT, Jouku. 200o. The perfect-aspectual, temporal and evidential. In: Östen Dahl, ed., Tense and Aspect in the Languages of Europe. Berlin: Mouton de Gruyter, 366-383.

LindSTRÖM, LiInA \& IlONA TrAgEL. 2010. The possessive perfect construction in Estonian. Folia Linguistica 44.2, 371-400.

Lindström, Liina, Nicole Nau, Biruté Spraunienė \& Asta LAUGALIENE். 2020. Impersonal constructions with personal reference.: Referents of deleted actors in Baltic and Estonian. Baltic Linguistics 11: Studies in the Voice Domain in Baltic and Its Neighbours (thematic issue), 129-213.

Malchukov, Andrej \& Anna Siewierska. 2011. Introduction. In: Andrej Malchukov \& Anna Siewierska, eds., Impersonal Constructions: A CrossLinguistic Perspective. Amsterdam-Philadelphia: John Benjamins, 1-15.

MLLVG I, 1959 = Mūsdienu latviešu literārās valodas grammatika. I. Fonētika un morfologija [Grammar of Modern Literary Latvian I. Phonetics and Morphology], ed. E. Sokols. Rīga: LPSR Zinātṇu akadēmijas izdevniecība.

NAU, Nicole. 2005. Perfekts un saliktā tagadne latviešu valodā [Perfect and compound present in Latvian]. Baltu filoloǵija XıV.2, 137-154.

Nau, Nicole \& Axel Holvoet. 2015. Voice in Baltic: An overview. In: Axel Holvoet \& Nicole Nau, eds., Voice and Argument Structure in Baltic. Amsterdam-Philadelphia: John Benjamins, 1-36. 
Nedjalkov, Vladimir P. \& Sergej Je. Jaxontov 1988. The typology of resultative constructions. In: Vladimir P. Nedjalkov, ed., Typology of Resultative Constructions. Amsterdam: John Benjamins, 3-62.

Shibatani, Masayoshi. 2006. On the conceptual framework for voice phenomena. Linguistics 44.2, 217-69.

Siewierska, Anna. 2013. Passive Constructions. In: Matthew S. Dryer \& Martin Haspelmath, eds., The World Atlas of Language Structures Online. Leipzig: Max Planck Institute for Evolutionary Anthropology. (Available online at http://wals.info/chapter/107, Accessed on 2020-02-16.)

Siewierska, AnnA \& Dik BAKker. 2012. Passive agents: prototypical vs. canonical passives. In: Dunstan Brown, Marina Chumakina \& Greville G. Corbett, eds., Canonical Morphology and Syntax. Oxford: Oxford University Press, 151-189. https://doi.org/10.1093/acprof:0so/9780199604326.003.0007.

Siewierska, Anna \& Maria Papastathi. 2011. Towards a typology of third person plural impersonals. Linguistics 49.3, 575-610.

Sprauniené, Biruté, Auksé Razanovaité \& Erika Jasionyté. 2015. Solving the Puzzle of the Lithuanian passive. In: Axel Holvoet \& Nicole Nau, eds., Voice and Argument Structure in Baltic. Amsterdam-Philadelphia: John Benjamins, 323-366.

TAYLOR, JOHN. 2007. Latin beyond GCSE. London: Bloomsbury.

Veidemane, RutaA. 2002. Darbības vārds [The verb]. In: Kornēlija Pokrotniece, ed., Latviešu literārās valodas morfologiiskās sistēmas attīstība: Lokāmās vārdšķiras [The Evolution of the Morphological System of Standard Latvian: Declinable Parts of Speech]. Rīga: LU Latviešu valodas institūts, 409-509.

Van Valin, Robert D. 2001. An Introduction to Syntax. Cambridge: Cambridge University Press.

VladARSKIENE, RASUOLE். 2004. Sintaksiniu priemoniu ypatybés valstybès dokumentu kalboje [Syntactic features in the language of state documents]. Vilnius: Lietuvių kalbos instituto leidykla.

WIEMER, BJÖRn. 2004. The evolution of passives as grammatical construction in Northern Slavic and Baltic languages. In: Walter Bisang, Nikolaus Himmelmann \& Björn Wiemer, eds., What Makes Grammaticalization? A Look from its Fringes and its Components. Berlin: Mouton de Gruyter, 271-331. 
WiEMER, BJöRn. 2006a. Grammatical evidentiality in Lithuanian (a typological assessment). Baltistica 41.1, 33-49.

WIEMER, BJÖRN. 2006b. Relations between actor-demoting devices in Lithuanian. In: Werner Abraham \& Larisa Leisiö, eds., Passivization and Typology (Form and Function). Amsterdam: John Benjamins, 274-309.

WiEMER, BJörn. In the press. On the rise, establishment and continued development of subject impersonals in Polish, East Slavic and Baltic. In: Seppo Kittilä \& Leonid Kulikov, eds., Diachronic Typology of Voice and Valency-Changing Categories. Amsterdam-Philadelphia: John Benjamins.

Willett, Thomas L. 1988. A cross-linguistic survey of the grammaticalization of evidentiality. Studies in Language 12, 51-97.

Zúñiga, Fernando \& Seppo Kittilä. 2019. Grammatical Voice. Cambridge: Cambridge University Press. https://doi.org/10.1017/9781316671399.

\section{Nicole Nau}

Vilnius University

Institute for the Languages and Cultures of the Baltic

\& Adam Mickiewicz University in Poznań

Department of Scandinavian Studies

al. Niepodlegtości 4, PL-61-874 Poznań

naunicol@amu.edu.pl

\section{Birutė Spraunienè}

\section{Vaiva Žeimantienè}

Vilnius University

Institute for the Languages and Cultures of the Baltic

Universiteto 5, LT-O1513 Vilnius

birute.sprauniene@flf.vu.lt

vaiva.zeimantiene@flf.vu.lt 